\title{
EFEITO DE ÓLEO DE SOJA NA PERSISTÊNCIA DE ENDOSULFAN NO AMBIENTE
}

\author{
CÉLIA MARIA DIAS CORRÊA
}

Tese apresentada à Escola Superior de Agricultura "Luiz de Queiroz", Universidade de São Paulo, para obtenção do título de Doutor em Ecologia de Agroecossistemas.

PIRACICABA

Estado de São Paulo - Brasil

Abril - 2005 


\title{
EFEITO DE ÓLEO DE SOJA NA PERSISTÊNCIA DE ENDOSULFAN NO AMBIENTE
}

\author{
CÉLIA MARIA DIAS CORRÊA \\ Engenheiro Agrônomo
}

Orientador: Prof. Dr. ARQUIMEDES LAVORENTI

Tese apresentada à Escola Superior de Agricultura "Luiz de Queiroz", Universidade de São Paulo, para obtenção do título de Doutor em Ecologia de Agroecossistemas.

PIRACICABA

Estado de São Paulo - Brasil

Abril - 2005 
Dados Internacionais de Catalogação na Publicaçăo (CIP) DIVISĀO DE BIBLIOTECA E DOCUMENTAÇĀO - ESALQ/USP

Corrêa, Célia Maria Dias

Efeito de óleo de soja na persistência de endosulfan no ambiente / Célia Maria Dias Corrêa .- Piracicaba, 2005.

$85 \mathrm{p}$.

Tese (doutorado) - - Escola Superior de Agricultura Luiz de Queiroz, 2005. Bibliografia.

1. Inseticida - Interaçäo 2. Óleo vegetal 3. Solo - Efeito. I. Titulo

CDD 632954

"Permitida a cópia total ou parcial deste documento, dos do que citada a fonte - 0 autor" 
Para ser o que sou hoje, fui vários homens e se volto a encontrar-me com os homens que fui, não me envergonho deles.

Foram etapas do que sou.

Tudo o que sei custou às dores das experiências.

Tenho respeito pelos que procuram, pelos que tateiam, pelos que erram.

$E$, o que é mais importante, estou persuadido de que minha luz se extinguiria se eu fosse o único a possuí-la.

Goethe. 


\section{DEDICATÓRIA}

A Deus pela fé, coragem, sabedoria, paciência, esperança em todos os momentos. Aos meus pais Engracia e Manoel pelo amor e apoio.

Aos meus filhos Lucas e Gustavo pela compreensão dos momentos divididos. Aos meus irmãos Francisco e Maria pelo carinho. Aos eternos amigos Nairzinha e Benedito pelas sábias palavras. 


\section{AGRADECIMENTOS}

Ao amigo e orientador Dr. Arquimedes Lavorenti, professor do Departamento de Ciências Exatas da Escola Superior de Agricultura "Luiz de Queiroz" - ESALQ/USP, pela orientação e compartilhamento do desafio deste trabalho.

Ao amigo e co-orientador Dr. Valdemar Luiz Tornisielo, professor do Centro de Energia na Agricultura - CENA/USP, pela orientação e disponibilidade da infra-estrutura do Laboratório de Ecotoxicologia na condução dos testes desenvolvidos.

A amiga e integrante do comitê de orientação professora Dra. Elke Jurandy Bran Cardoso Nogueira, pela disposição de toda sua experiência na área de microbiologia de solos e oportunidade de desenvolvimento de pesquisas no Laboratório de Microbiologia de Solos - ESALQ/USP.

A amiga e professora Dra. Silvia Guerra Molina, pela disposição de toda sua experiência e oportunidade de desenvolvimento de pesquisas no Departamento de Genética ESALQ/USP.

Aos pesquisadores Dra. Rosa Toyoko S. Friguetto e Dr. Itamar Soares de Melo do Centro Nacional de Pesquisa de Monitoramento e Avaliação de Impacto Ambiental CNPMA/EMBRAPA, pela participação do comitê de avaliação e valiosas sugestões.

Aos amigos do Departamento de Solos e Nutrição de Plantas - ESALQ, Denise, Daiane, Fernando, Pereira, Paulo, Fernanda e Alexandre pelas sugestões e amizade em todos os momentos. 
Às amigas do Departamento de Genética - ESALQ, Luana, Ligia e Ana Paula pelo carinho.

Ao Prof. Dr. Gilberto Casadei Baptista e ao Dr. Luís Roberto Pimentel Trevizan do Departamento de Entomologia, Fitopatologia e Zoologia Agrícola - ESALQ, pela disponibilidade do Laboratório de Resíduos de Pesticidas.

Aos amigos do Laboratório de Ecotoxicologia - CENA, Jussara, Rosângela, Luciene, Rui, Lucineide, Dorelli pela amizade em todos os momentos.

As amigas do Departamento de Ecologia Aplicada - ESALQ, Alba e Ana Paula.

Aos amigos da Bioagri Laboratórios Ltda. pela disposição da infra-estrutura para condução de parte deste estudo, em especial Paulo Silva, Alex, Diego, Junior e Vanessa.

À empresa Stoller do Brasil Ltda. por ter cedido os óleos vegetais, emulsificantes e o Natur'l Oil.

À empresa Nortox S.A. por ter cedido o endosulfan técnico, os padrões analíticos e o material radiomarcado.

Aos amigos e companheiros que, de alguma maneira, contribuíram para a realização deste trabalho e que se fizeram presente na multiplicação dos bons momentos e divisão das horas difíceis.

À CAPES pela bolsa de estudo concedida. 


\section{SUMÁRIO}

Página

LISTA DE FIGURAS ….................................................................... $\mathrm{x}$

LISTA DE TABELAS .............................................................................

LISTA DE QUADROS ................................................................................ xiii

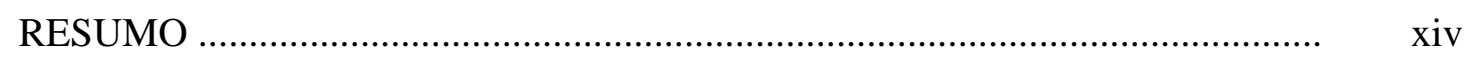

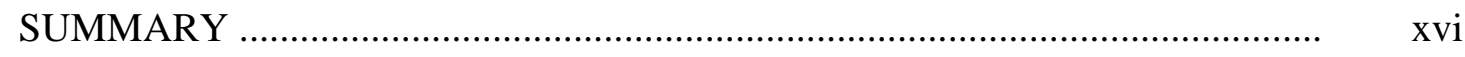

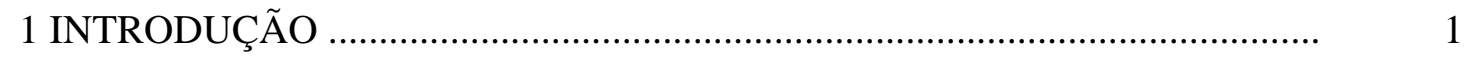

2 REVISÃO DE LITERATURA .................................................................... 5

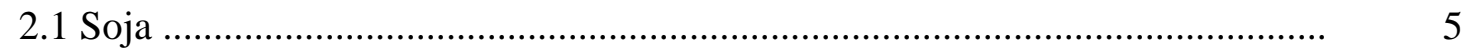

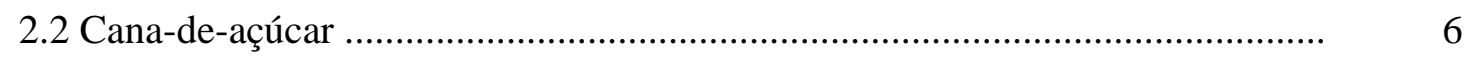

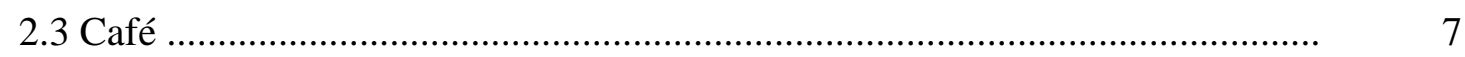

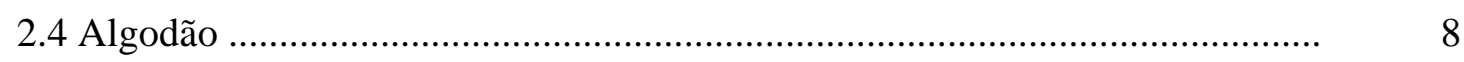

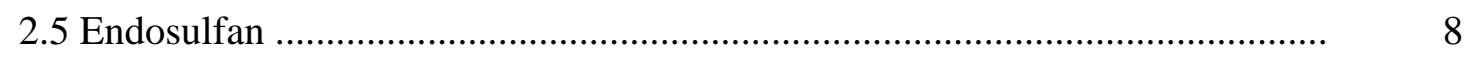

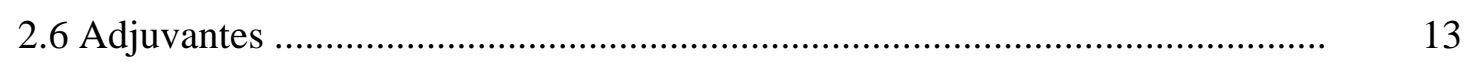

2.7 Transformação de pesticidas ......................................................................... 16

2.7.1 Metodologia para análise de dióxido de carbono $\left(\mathrm{CO}_{2}\right)$................................. 27

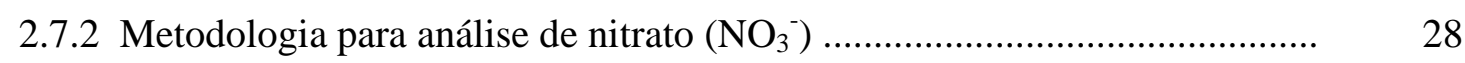

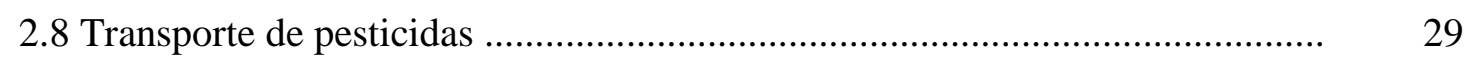

3 MATERIAL E MÉTODOS ......................................................................... 34

3.1 Avaliação do efeito do endosulfan no crescimento fúngico de Aspergillus sp (linhagem Cad G1) em meio de cultura na presença e ausência do óleo

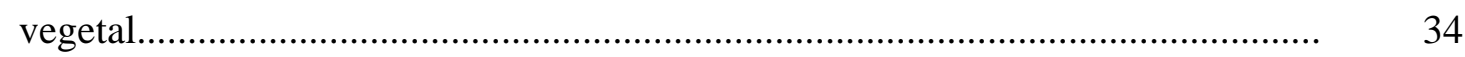

3.1.1 Materiais e Equipamentos .......................................................................... 34 
3.1.2 Substância teste ..............................................................................

3.1.3 Preparo do meio de cultura ................................................................... 35

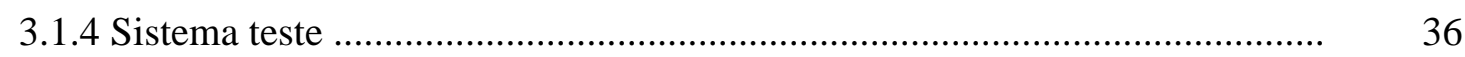

3.1.5 Condições de incubação ........................................................................... 36

3.1.6 Tratamentos ......................................................................................... 36

3.2 Teste de transformação de carbono ................................................................. 38

3.2.1 Materiais e Equipamentos ......................................................................... 38

3.2.2 Metodologia ..................................................................................... $\quad 39$

3.2.2.1 Preparo dos tratamentos ............................................................................... 41

3.2.2.2 Avaliação do dióxido de carbono $\left(\mathrm{CO}_{2}\right)$.................................................. 41

3.3 Teste de transformação de nitrogênio ................................................................ 43

3.3.1 Materiais e Equipamentos ........................................................................... 43

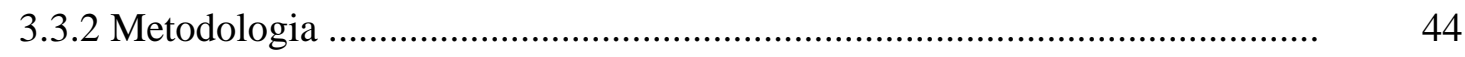

3.2.2.1 Preparo dos tratamentos ........................................................................... 44

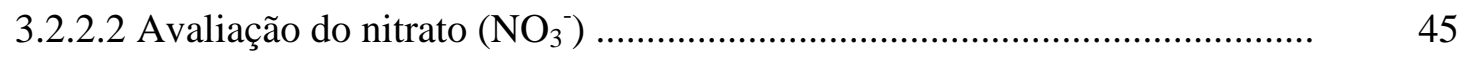

3.4 Teste de lixiviação ..................................................................................... 47

3.4.1 Materiais e Equipamentos ..................................................................... 47

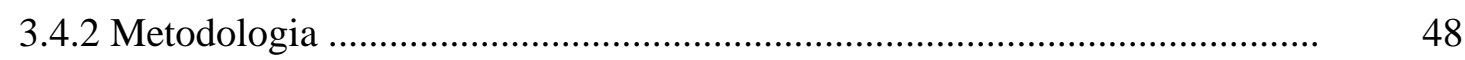

3.4.2.1 Preparo dos tratamentos ........................................................................... 49

3.4.2.2 Coleta do lixiviado ........................................................................... 50

3.4.2.3 Seccionamento das colunas de solo ..................................................... 50

3.5 Teste de biodegradabilidade em solos ......................................................... 51

3.5.1 Materiais e Equipamentos ..................................................................... 51

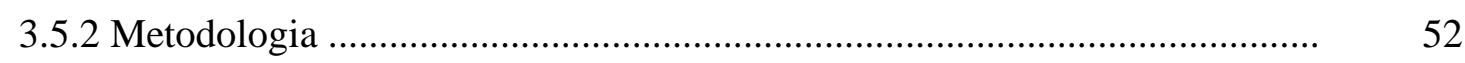

3.5.2.1 Preparo dos tratamentos ....................................................................... 53

3.5.2.2 Avaliação do dióxido de carbono $\left({ }^{14} \mathrm{CO}_{2}\right)$............................................... 54

3.5.2.3 Amostragem e extração do solo .............................................................. 54

3.5.2.4 Determinação da atividade microbiana do solo (radiorespirometria) ........ 55

3.5.2.5 Combustão de solo para determinação do resíduo ligado .......................... 56

4 RESULTADOS E DISCUSSÃO ............................................................... 57 
4.1 Avaliação do efeito do endosulfan no crescimento fúngico de Aspergillus sp (linhagem Cad G1), em meio de cultura na presença e ausência de óleo

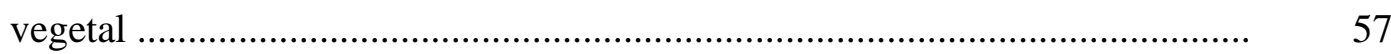

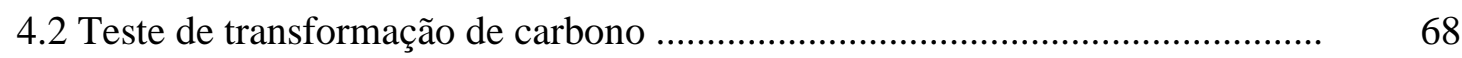

4.3 Teste de transformação do nitrogênio ............................................................. 71

4.4 Teste de lixiviação ................................................................................

4.5 Teste de biodegradabilidade em solos .......................................................... 76

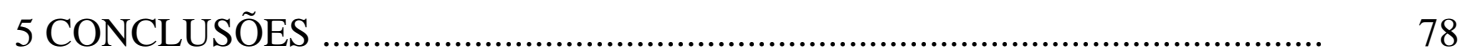

REFERÊNCIAS BIBLIOGRÁFICAS .......................................................... 79 


\section{LISTA DE FIGURAS}

Página

1 Estruturas moleculares do $\alpha$-endosulfan(a), $\beta$-endosulfan (b) e endosulfan sulfato (c)

2 Comparação dos diâmetros das colônias da linhagem Cad G1 Aspergillus sp, após 6 dias de inoculação para os tratamentos: E+I (A); C+I (B); $\mathrm{OSDu}+\mathrm{E}+\mathrm{I}(\mathrm{C})$ e $\mathrm{OSDu}+\mathrm{EM}+\mathrm{I}(\mathrm{D})$

3 Ensaio de transformação de carbono em frascos herméticos com armadilha de $\mathrm{NaOH}$ para captura de $\mathrm{CO}_{2}$

4 Frasco com $10 \mathrm{~mL}$ de $\mathrm{NaOH}(0,2 \mathrm{M})$ e $\mathrm{BaCl}_{2}$ (saturado) para reação do $\mathrm{CO}_{2}$ capturado na presença do indicador fenolftaleína e titulação com $\mathrm{HCl}(0,1 \mathrm{M})$..

5 Placa de Elisa com os padrões de $\mathrm{KNO}_{3}$ para estabelecimento da curva padrão em função da absorbância

6 Extração de nitrato em amostras de solo no tratamento $\mathrm{C}+\mathrm{S}$ pelo método de brucina

7 Foto ilustrativa mostrando as colunas de vidro preenchidas com solo PV para o estudo de lixiviação de endosulfan na presença e ausência de Natur'l Oil ...... 50

8 Frasco de Bartha com solo e armadilha de $\mathrm{KOH}(0,1 \mathrm{M})$ para captura do ${ }^{14} \mathrm{CO}_{2}$.

9 Efeito da concentração, tipo e processamento do óleo vegetal e presença de endosulfan e(ou) adjuvante sobre o diâmetro das colônias de Aspergillus sp (linhagem Cad G1)

10 Avaliação do diâmetro médio (cm) das colônias de Aspergillus sp (linhagem Cad G1) no controle e na presença e ausência de endosulfan, Natur’l Oil 
emulsificante

11 Comparação de $\mathrm{CO}_{2}$ liberado no teste de transformação de carbono com o endosulfan, na presença e ausência do Natur'l Oil

12 Comparação de $\mathrm{NO}_{3}{ }^{-}$formado no teste de transformação de nitrogênio com o endosulfan, na presença e ausência do Natur'l Oil

13 Distribuição de ${ }^{14} \mathrm{C}$-endosulfan $(\%)$ nas secções de solo $(0-30 \mathrm{~cm})$, areia e lixiviado, na presença e ausência do Natur'l Oil

14 Distribuição de ${ }^{14} \mathrm{C}$-endosulfan (\%) nas secções de solo $(5-30 \mathrm{~cm})$, areia e lixiviado, na presença e ausência do Natur'l Oil

15 Concentração percentual de ${ }^{14} \mathrm{C}$ - endosulfan no balanço de massas, evolução de ${ }^{14} \mathrm{CO}_{2}$ e endosulfan extraído e oxidado para os tratamentos DMA e $\mathrm{DMA}+\mathrm{O}$ 


\section{LISTA DE TABELAS}

Página

1 Características físico-químicas do endosulfan .................................................... 9

2 Diâmetro médio das colônias fúngicas para todos os tratamentos propostos ..... 58

3 Análise de variância de médias de diâmetro de colônia da linhagem Cad G1 de Aspergillus sp cultivada em meio com dois tipos de óleo (girassol ou soja), submetidos a dois processamentos (refinamento ou degomagem), duas concentrações do óleo (0,1 e 0,5\%) e duas composições do pesticida adicionadas ao meio (endosulfan com emulsificante ou apenas emulsificante) .

4 Teste de Tukey para comparação de médias de diâmetro de colônia da linhagem Cad G1 de Aspergillus sp cultivada em meios com diferentes composições (dados não transformados)

5 Regressão Polinomial para comparação do efeito da concentração do óleo no meio de cultivo $(0,1 \%$ ou $0,5 \%)$ sobre as médias de diâmetro de colônia da linhagem Cad G1 de Aspergillus sp cultivada em meios com diferentes composições - (dados não transformados)

6 Resultado das análises químicas e granulométricas do solo Argissolo Vermelho Amarelo Eutrófico Abrúptico (PV) 


\section{LISTA DE QUADROS}

Página

1 Preparo do meio de cultivo mínimo para crescimento de fungos ....................... 35

2 Descrição dos tratamentos utilizados no experimento de placas ......................... 37 


\title{
EFEITO DE ÓLEO DE SOJA NA PERSISTÊNCIA DE ENDOSULFAN NO AMBIENTE
}

\author{
Autora: CÉLIA MARIA DIAS CORRÊA \\ Orientador: Prof. Dr. ARQUIMEDES LAVORENTI
}

\section{RESUMO}

Os pesticidas fazem parte do conjunto de tecnologias associadas à modernização da agricultura e com o uso generalizado destes muitos problemas começaram a ser diagnosticados, entre eles, a contaminação de solos e água. A permanência no ambiente está relacionada às características físico-químicas destes produtos, bem como as do ambiente, que definem processos de transporte, retenção e transformação entre compartimentos ambientais. Em âmbito mundial, o emprego de técnicas que visem a minimizar o número de aplicações, produtos que possibilitem uma degradação microbiana mais rápida e síntese de produtos com menor potencial de contaminação ambiental pode vir a corroborar no processo de racionalização e segurança do uso de pesticidas, como também preservar a biodiversidade da microbiota do solo. Os espalhantes adesivos são empregados na agricultura como adjuvantes na aplicação de pesticidas. Até o presente momento se conhecem estudos de eficácia de controle de agentes nocivos na presença e ausência de adjuvantes, mas pouco se conhece dos efeitos combinados dos mesmos com pesticidas no ambiente. Este estudo teve como objetivo verificar o efeito do óleo vegetal na persistência de endosulfan, inseticida que apresenta uso relevante em culturas de importante projeção no setor de agronegócios no Brasil. A priori foi conduzido um teste para selecionar o óleo mais adequado entre soja e girassol, sob processos degomado e refinado utilizando-se placas com meio de cultura e 
inoculação com Aspergillus sp (CAD G1), onde se observou um aumento de 81,07\% do crescimento da colônia na presença do óleo de soja degomado e endosulfan $(\mathrm{OSDu}+\mathrm{E}+\mathrm{I})$ comparado a ausência do óleo de soja $(\mathrm{E}+\mathrm{I})$. Diante dos resultados apresentados optou-se pelo óleo de soja degomado, cujo produto comercial é o Natur'l Oil. Os processos supracitados foram avaliados através de estudos de transformação de carbono e nitrogênio por microrganismos do solo, de lixiviação e biodegradabilidade em solos, testando as seguintes concentrações: DMA (700 g de endosulfan/ha) e DMA+O (700 g de endosulfan/ha misturado a 2L/ha de Natur'l Oil). Os resultados mostraram que estatisticamente não houve diferenças nos testes de transformações de carbono e nitrogênio, como biodegradabilidade em solos, quando comparados os tratamentos na ausência e presença do Natur'l Oil. Os resultados do teste de lixiviação mostram os seguintes percentuais de endosulfan: 91,68 e 66,04 no solo e para o lixiviado 5,18 e 4,98 nos tratamentos DMA e DMA+O, respectivamente. Os valores de lixiviado não diferiram entre si estatisticamente, no entanto no solo observou-se que a presença do Natur'l Oil promove uma menor adsorção do endosulfan e maior dissipação. Tendo em vista que a presença do Natur'l Oil não interfere nos processos de transformação de carbono e nitrogênio e no teste de biodegradabilidade do endosulfan em solos e que no processo de lixiviação a presença do óleo trouxe incrementos positivos, desfavorecendo a percolação do pesticida, a adição de óleos vegetais, como espalhante adesivo, deve ser considerada na aplicação de pesticidas para redução de lixiviação e por evitar o contato direito dos pesticidas com os microrganismos de solo, proporcionando uma maior fase lag e a preservação da biodiversidade. 


\section{EFFECT OF SOYBEAN OIL IN THE ENDOSULFAN PERSISTENCE IN THE ENVIRONMENT}

Author: CÉLIA MARIA DIAS CORRÊA

Adviser: Prof. Dr. ARQUIMEDES LAVORENTI

\section{SUMMARY}

The pesticides make part of a technology that is associated to the agriculture modernization. With their generalized use many problems occur and are diagnosed, among others, the water and soil contamination. The persistence in the environment is related to their physical and chemical properties, as well to the environment that defined the transport, retention and transformation processes in environment compartments. In world wide point of view, techniques that try to minimize the number of applications, the use of products that possibility a fast microbial degradation and synthesis of products with lower potential to the environmental contamination can help the rationalization process and safer use of pesticides, in order to preserve the biodiversity of the soil microbiota. The adhesive dispersed are used in agriculture as adjuvants to the pesticide application. Until now efficacy control studies in harmful agents with pesticides in the presence and absent of adjuvants have been known, but there are few knowledge about their combined effects in the soil. This study had the objective to verify the effect of vegetable oil in the persistence of the endosulfan, the inseticide that shows a considerable use in cultures with important projection in the Brazil agribusiness sector. At first a test was conducted to select the more suitable oil, between soybean and sunflower, under degumming and refined processes using plates with culture medium and inoculated with fungi Aspergillus sp (CAD G1). In the plates test observed that the 
colony diameter increased in $81.07 \%$ in the presence of the soybean degumming oil and endosulfan $(\mathrm{OSDu}+\mathrm{E}+\mathrm{I})$ compared with the absence soybean degumming oil $(\mathrm{E}+\mathrm{I})$. In front of the presented results, the soybean degumming oil added with emulsifier (OSDu) was chosen, which commercial product is the Natur'l Oil. The mentioned processes were evaluated by studies: carbon and nitrogen transformation by soil microorganisms, leaching and biodegradability in soils testing the following concentrations: DMA (700 g of endosulfan /ha - DMA) and DMA+O (700 g of endosulfan mixed with the 2L/ha of Natur'l Oil). The results showed that statistically there were not significant differences in the carbon and nitrogen transformations, such in the biodegradability test in the soil, when compared the treatments in presence and absent of the Natur'l Oil. The leaching results showed the following the endosulfan percents: 91.68 and 66.04 in the soil and 5.18 and 4.98 in the leached, for treatments DMA and DMA+O, respectively. The leached values were not statically different. However, for soil results observed that the presence of Natur'l Oil promotes a lower adsorption of endosulfan and higher dissipation. In fact the presence of Natur'l Oil did not affect the carbon and nitrogen transformation and biodegradability test of endosulfan in soil and in the leaching process, the presence of oil brought positives increments, disfavoring the pesticide percolation. The added of oils like adhesive dispersed should be considerate in pesticide application to reduce the leaching and for avoid the direct contact of pesticides with soil microorganisms, providing a higher lag phase and the biodiversity preservation. 


\section{INTRODUÇÃO}

Culturas como soja e cana-de-açúcar vêm ganhando relevante projeção no setor de agronegócios no Brasil. Vários fatores ao longo dos anos contribuíram para a atual competitividade brasileira, incluindo maior produtividade e rendimento industrial, pesquisas sobre novas variedades, utilização de novas técnicas agrícolas e pesticidas mais eficientes.

O complexo soja é o principal item do Balanço Comercial Brasileiro, trazendo mais de US\$ 11 bilhões em divisas em 2004, o que coloca o produto em primeiro lugar da pauta de exportações, confirmando forte expansão por todo o cerrado brasileiro, bem como estados do Nordeste, para atingir de maneira satisfatória à ampla demanda do grão e dos seus derivados.

A produtividade sucro-alcooleira vem crescendo nos últimos anos com ampla diversificação geográfica, regiões Centro-Sul e Norte-Nordeste, estando atualmente em 77 toneladas de cana por hectare. Os 10 principais produtores são responsáveis por 76\% da produção mundial de açúcar, com o Brasil desempenhando um papel de liderança tanto na produção, como na exportação de açúcar. O açúcar de cana é responsável por 75\% da produção mundial.

O interesse no uso do álcool como combustível, tem-se revigorado ultimamente, devido à necessidade de substituição gradativa dos combustíveis fósseis por fontes renováveis e menos poluentes.

Os ganhos de produtividade das culturas são reflexos de um conjunto de ações contínuas e investimentos em pesquisa e tecnologia, cabendo destacar que os agricultores estão investindo em tecnologias, contribuindo sensivelmente para o aumento das vendas de insumos modernos, representando incrementos significativos no consumo de pesticidas do Brasil. 
O endosulfan é um inseticida e acaricida com ação de contato e ingestão e foi desenvolvido pelo laboratório da Hoechst AG em 1952, e desde então, vem sendo utilizado em larga escala. A despeito de seu grande espectro de ação, é bem tolerado por uma série de insetos benéficos e têm se mostrado efetivo para uma grande variedade de pragas, no caso Hemíptera, Lepidóptera, Homóptera, Coleóptera, Isóptera, Thysanóptera e Orthóptera, que são as de maior importância agrícola, além de ácaros.

Atualmente o endosulfan tem seu uso liberado às culturas de algodão, cacau, café, cana-de-açúcar e soja, sendo a formulação, concentrado emulsionável, a principal forma de comercialização do endosulfan.

Com registro autorizado para culturas com amplas abrangências geográficas, até o presente momento este pesticida continua gerando polêmicas sobre sua utilização, dividindo as opiniões em duas vertentes: expressiva toxicidade para organismos aquáticos e a alta eficiência no controle de pragas, bem como a seletividade a insetos benéficos, sendo muito utilizado no manejo integrado de pragas (MIP).

Os óleos vegetais vêm sendo empregados como espalhantes adesivos, que são largamente utilizados na aplicação de pesticidas e controle de cochonilhas, quando misturados às moléculas de pesticidas, os óleos criam uma barreira de proteção, proporcionando redução nas perdas por degradação, volatilização, deriva e lavagem da parte área das plantas por águas pluviais, melhorando o desempenho de inseticidas, fungicidas e herbicidas. A formulação de pesticidas preparados com óleos vegetais, como diluentes, deve ser considerada na busca de técnicas que visem, melhorar a eficiência, racionalizar o uso do controle químico e minimizar contaminações ambientais.

O grande aumento no uso de pesticidas é um dos meios para garantir a demanda mundial de alimentos e a produção de produtos de interesse, como combustível. Por outro lado, podem resultar no aumento da contaminação dos alimentos e do ambiente e riscos de intoxicações. Para minimizar a contaminação é necessário restringir o uso dos pesticidas mais persistentes, utilizar técnicas que visem acelerar os processos de degradação destes no ambiente, utilizar variedades mais resistentes e empregar programas de manejo integrado de pragas que, por implicar diretamente em 
reduções do custo de produção, da poluição ambiental, dos riscos de intoxicações e dos níveis de resíduos em alimentos, vem ganhando espaço junto aos agricultores.

Pesticidas e outros xenobióticos, uma vez introduzidos no ambiente, estão sujeitos aos processos de transformação biológicos e não biológicos como também processos de retenção e transporte. A avaliação dos processos de retenção, transporte e transformação de produtos químicos são relevantes, pois permite conhecer a persistência dos mesmos no ambiente.

Entre os processos biológicos, os microrganismos desempenham um papel importante na degradação de pesticidas, bem como na quebra e transformação biótica de matéria orgânica em solos férteis, com muitas espécies contribuindo para os diferentes aspectos da fertilidade do solo. Interferências nestes processos bioquímicos poderiam afetar potencialmente a ciclagem de nutrientes e até alterar a fertilidade do solo.

A aplicação sucessiva de pesticidas também acarreta em perda da biodiversidade da microbiota do solo, que atua diretamente na degradação destes produtos.

Estudos de transformação de carbono e nitrogênio, biodegradabilidade e lixiviação de pesticidas em solos fornecem respectivamente dados da taxa de mineralização, através da conversão de um elemento de uma forma orgânica para uma forma inorgânica e da distribuição destes produtos no ambiente, bem como o potencial de contaminação de águas subterrâneas.

No delineamento de um programa com o objetivo de racionalizar o uso de pesticidas deve-se considerar, não apenas as tecnologias e manejos disponíveis para a substituição do controle químico, mas também medidas que estimulem a geração de técnicas alternativas ao uso e aplicação de pesticidas pelos usuários.

Fato de suma importância é a possibilidade do uso de produtos com óleo de soja, como adjuvante, na aplicação de pesticidas, em culturas anuais como a soja, algodão, em culturas anuais de ciclo longo, como é o caso da cana-de-açúcar e culturas perenes, como é o caso do café e cacau, proporcionando um incremento na eficiência no controle de pragas, principalmente de solos. 
Outra aplicação seria a utilização em solos arenosos, como é o caso dos solos do cerrado e Nordeste, que devido ao baixo teor de matéria orgânica e argila proporcionam baixa adsorção, permitindo que o produto lixivie, contaminando águas subterrâneas.

Este trabalho teve como objetivos:

(a) Verificar o efeito do óleo de soja acrescido de endosulfan nos processos de transformação de carbono e nitrogênio em solo.

(b) Verificar o efeito do óleo de soja no processo de lixiviação do endosulfan em solos.

(c) Verificar o efeito do óleo de soja na biodegradabilidade do endosulfan em solos.

(d) Contribuir com subsídios para trabalhos futuros desenvolvidos na área de controle da contaminação e preservação do ambiente. 


\section{REVISÃO DE LITERATURA}

\subsection{Soja}

Em 2004, o complexo soja foi o principal item do Balanço Comercial Brasileiro trazendo divisas de mais de US\$ 11 bilhões, o que o coloca, disparado, no primeiro lugar da pauta de exportações do país, devendo crescer até 39\% em 2005. No entanto, apesar do contínuo crescimento da soja desde os anos 70, foi a partir de meados da década passada que a produção de soja apresentou seu melhor desempenho. Até então, havia restrições fundamentais para o crescimento da oleaginosa, principalmente no que refere à escassez e elevado custo de capital, tanto de curto prazo para financiamento da produção e comercialização, como de longo prazo, para promoção de investimentos em máquinas, implementos, benfeitorias, estrutura de armazenagem e outros. Atualmente a soja expandiu-se por todo o cerrado brasileiro, chegando hoje aos distantes Estados do Maranhão e do Piauí. (ABIOVE, 15/12/2004)

O sucesso da soja decorre, antes de tudo, do desenvolvimento de pesquisas e tecnologias inovadoras adaptadas à região tropical: novos cultivares, pesticidas, mecanização, técnicas de plantio direto, entre outras, confirmando uma forte expansão na área cultivada por soja.

Para atingir de maneira satisfatória à ampla demanda do grão e dos seus derivados, garantindo a competitividade do Brasil no mercado mundial, cabe destacar que o sojicultor está investindo em tecnologia, contribuindo sensivelmente para o aumento das vendas de insumos modernos, representando incremento significativo no consumo de pesticidas do Brasil.

A soja é a mais importante oleaginosa sob cultivo extensivo e também a planta de lavoura que mais produz proteína por hectare. Suas qualidades como fonte de 
calorias, fazem desta leguminosa o alimento básico potencial na luta contra o espectro da subnutrição e da fome, que já se vislumbra em áreas densamente populosas e menos desenvolvidas. Portanto, o desenvolvimento de novas áreas de produção e a difusão do consumo da soja podem ser fundamentais para o suprimento diário de grande parte da população de diferentes latitudes (Bonetti et al., 1981).

Confirmando esta tendência, a soja pelas suas qualidades nutricionais, facilidade de adaptação, alta produtividade e cultivo em quase todas as regiões do globo, é considerada como um dos alimentos do futuro, tendo visto ser a melhor fonte de proteína de baixo custo e de alto valor nutritivo que se conhece para a alimentação humana (Costa, 1978).

\subsection{Cana-de-açúcar}

O açúcar proveniente da cana-de-açúcar é responsável por 75\% da produção mundial. Apesar da forte onda de adoçantes das últimas décadas, o consumo de açúcar no mundo vem crescendo a uma taxa média anual de 2,3\%.

O Brasil é o maior exportador mundial de açúcar e, junto com a Austrália e alguns países da América Central e do Sul, é um dos poucos países a exportar mais do que o consumo doméstico. Isso faz com que a busca pela competitividade seja incessante, sendo o único país a contar com dois períodos de safra distintos. As regiões Norte-Nordeste colhem sua safra no período de novembro a abril, enquanto que as regiões Centro-Sul de maio a outubro. A região Centro-Sul representa cerca de 85\% da produção de cana, açúcar e álcool, e vem apresentando forte crescimento nas últimas safras. Assim, o país desfruta não apenas de interessante diversificação geográfica, mas também de maior equilíbrio na safra.

Os ganhos de produtividade, atualmente em 77 toneladas de cana por hectare, são reflexos de um conjunto de ações contínuas e investimentos em pesquisa e tecnologia.

O Brasil permanece sendo o país, onde o cultivo da cana-de-açúcar de menor custo no mundo, sendo que vários fatores, ao longo dos anos, contribuíram para a atual 
competitividade brasileira, incluindo maior produtividade e rendimento industrial, pesquisas sobre novas variedades, utilização de novas técnicas agrícolas e solos mais produtivos. Os 10 principais produtores são responsáveis por 76\% da produção mundial de açúcar, com o Brasil desempenhando um papel de liderança tanto na produção, como na exportação de açúcar.

O mercado do álcool ainda é bastante restrito e, devido ao grande consumo interno do combustível, a maior parte da produção ainda é destinada ao mercado interno. Esse crescimento de consumo indica um volume de 40 milhões de toneladas na próxima década, ou seja, duas vezes a produção brasileira. Apesar do crescimento mundial do álcool na última década, o mercado de álcool ainda pode ser considerado incipiente. O interesse no uso do álcool como combustível, tem-se revigorado ultimamente, devido ao aumento dos preços do petróleo e à necessidade de redução de emissão de gases poluentes causadores do efeito estufa.

A solução para as questões ambientais do planeta caminha para a substituição gradativa dos combustíveis fósseis por fontes renováveis, como os vegetais derivados da biomassa.

Os produtores de açúcar e álcool estão vivendo uma onda de otimismo e de investimentos no Brasil. Com a venda de carros bicombustíveis em alta e as incertezas mundiais em relação ao petróleo, até 2010 o volume de recursos aplicados no setor atingirá US\$ 6 bilhões, segundo levantamento feito pela União da Agroindústria Canavieira de São Paulo. No mesmo período, a área plantada passará de 5,5 milhões para 7,5 milhões de hectares. Espera-se a criação de 400 mil empregos diretos, em 40 novas usinas - algumas das quais entram em operação até o fim do ano. Desde o período de ouro do Proálcool o setor não vivia momento tão especial, e o otimismo se reforçou na semana passada, com a vitória brasileira sobre os subsídios europeus à produção de açúcar. (O Estado de São Paulo, 08/08/2004).

\subsection{Café}

Com tradição secular no mercado internacional, o Brasil nunca exportou tanto café como agora. As vendas da safra 2002/03, encerradas em 30 de junho, foram de 
28,27 milhões de sacas de 60 quilos e coloca o país em posição de destaque no mercado internacional, com 33\% de participação no comércio mundial de café, um aumento de 20\% sobre o período anterior. O aumento da participação se verifica, principalmente, desde 2001, quando as vendas brasileiras somaram 23,1 milhões de sacas, um aumento de 28,6\% sobre o período de 2000. Neste ano, o Brasil abocanhou 25,7\% do mercado mundial, segundo dados da Coffee Business (Franco, 2003).

A colheita recorde, de 48 milhões de sacas no período 2002/03, deu fôlego suficiente para que o País aumentasse sua presença no mercado externo, alcançando 31,5\% em 2002 e mantendo 33\% durante o ano safra 2002/03. Estimativas iniciais indicaram exportações de 26,5 milhões de sacas ao longo de 2003, garantindo ao Brasil algo em torno de 30\% de participação do mercado (Franco, 2003).

Os produtores brasileiros de café estão comemorando os bons resultados de 2004. Maior produtor do mundo, 48 milhões de sacas por ano, o Brasil caminha para se tornar também o maior consumidor do produto, superado apenas pelos Estados Unidos (ABIC,2005).

\subsection{Algodão}

O algodão pode seguir o caminho da soja. Em dois anos, o preço do algodão mais que dobrou e novas áreas de produção surgem no Brasil, principalmente na Bahia, Mato Grosso e Mato Grosso do Sul. O produto já está sendo chamado de ouro branco brasileiro, mais ainda após a Organização Mundial do Comércio dar razão ao País na reclamação contra os subsídios americanos aos produtores. Otimistas, os cotonicultores projetam para o algodão um desempenho como o da soja, que é hoje o principal produto da agricultura brasileira e que, nesta safra, deve gerar uma renda de R \$ 42,1 bilhões aos produtores. (O Estado de São Paulo 09/05/2004)

\subsection{Endosulfan}

O inseticida e acaricida endosulfan apresenta expressiva toxicidade ao ambiente aquático e também alta eficácia, devido ao seu amplo espectro de ação. Está sendo bastante utilizado no Manejo Integrado de Pragas (MIP) em soja, bem como 
culturas de algodão, cacau e café, tendo mais recentemente seu registro liberado para a cana-de-açúcar (Andrei, 1999).

O inseticida endosulfan, 6,7,8,9,10, 10 - hexacloro-1,5, 5a, 6, 9, 9a- hexahidro6, 9, metano-2,4,3-benzo dioxatiepin-3-óxido (IUPAC), teve origem nos estudos de análogos de cadeia aberta do clordane, desenvolvidos pela Hoechst Aktiengesellschaft na Alemanha, segundo Goebel et al. (1982). O ingrediente ativo consiste na mistura de dois isômeros, sendo $70 \% \alpha$-endosulfan e 30\% de $\beta$-endosulfan (Lehr, 1992).

Segundo Werner et al. (1987) e Robert \& Hutson (1999), algumas informações do produto estão apresentadas na Tabela 1.

Tabela 1. Características físico- químicas do endosulfan

\begin{tabular}{|c|c|c|c|}
\hline Molécula & $\alpha$ - endosulfan & $\beta$ - endosulfan & Endosulfan sulfato \\
\hline $\mathrm{Koc}^{1}$ & 13.000 & 11.600 & 8.500 \\
\hline Massa molecular ${ }^{2}$ & 406,9 & 406,9 & 422,9 \\
\hline Fórmula molecular & $\mathrm{C}_{9} \mathrm{H}_{6} \mathrm{Cl}_{6} \mathrm{O}_{3} \mathrm{~S}$ & $\mathrm{C}_{9} \mathrm{H}_{6} \mathrm{Cl}_{6} \mathrm{O}_{3} \mathrm{~S}$ & $\mathrm{C}_{9} \mathrm{H}_{6} \mathrm{Cl}_{6} \mathrm{O}_{4} \mathrm{~S}$ \\
\hline Solubilidade & \multirow{3}{*}{\multicolumn{3}{|c|}{$\begin{array}{l}\text { Baixa solubilidade em água }\left(0,33 \mathrm{mg} \mathrm{l}^{-1}\left(22^{\circ} \mathrm{C}\right) \text {, prontamente }\right. \\
\text { solúvel em diclorometano, hexano, tolueno, acetona e álcoois. } \\
\alpha 4,74 \text { e } \beta 4,79 \text { (ambos para pH 5) } \\
8,3 \text { x } 10^{-4} \mathrm{~Pa}\left(25^{\circ} \mathrm{C}\right) \text { para a mistura de isômeros } \alpha \text { e } \beta \text { - } \\
\text { endosulfan } 2: 1 \text {. }\end{array}$}} \\
\hline $\log K_{\text {ow }}^{3}$ & & & \\
\hline Pressão de vapor & & & \\
\hline
\end{tabular}

Fontes: Werner et al. (1997) e Roberts \& Hutson (1999)

${ }^{1}$ Koc constante de adsorção relacionado com o carbono orgânico do solo

${ }^{2}$ Expressa em g mol ${ }^{-1}$

${ }^{3} \mathrm{~K}_{\mathrm{ow}}$ constante de partição octanol-água

A baixa solubilidade do endosulfan e dos seus metabólitos é a razão para sua alta adsorção às partículas orgânicas do solo, e caracteriza sua baixa mobilidade (Lehr, 1992). 
O comportamento dos agrotóxicos no solo é de extrema complexidade por implicar em numerosas interações entre as fases sólidas, líquidas e gasosas. O processo de adsorção/dessorção dos agrotóxicos, pelos colóides orgânicos e inorgânicos do solo é de natureza físico-química e controla a concentração do produto na solução do solo, determinando a sua atividade biológica, mobilidade e volatilidade (Lavorenti, 1997).

Na Figura 1 podemos verificar as estruturas moleculares do $\alpha$-endosulfan, $\beta$-endosulfan e endosulfan sulfato.

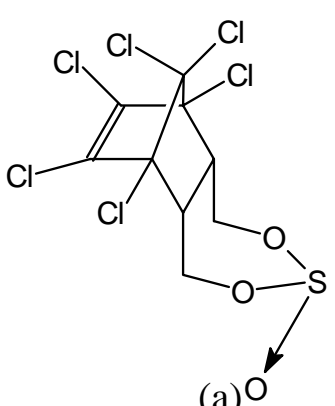

(a) $\mathrm{O}$

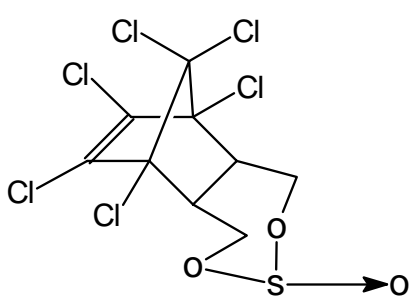

(b)

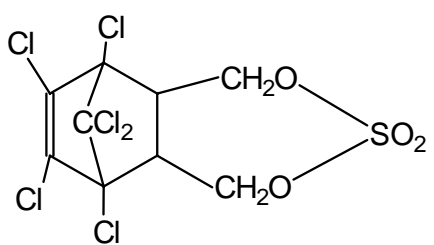

(c)

Figura 1- Estruturas moleculares do $\alpha$-endosulfan (a), $\beta$-endosulfan (b) e endosulfan sulfato (c)

Segundo Lehr (1993), a degradação do endosulfan ocorre por dois processos, sendo um químico, outro fotoquímico.

Quanto ao processo químico, Goebel et al. (1982) sugere dois mecanismos de degradação química: a hidrólise dando formação ao endosulfan diol e a oxidação originando o sulfato de endosulfan, que é o principal resíduo depois da aplicação do produto.

A degradação fotoquímica se dá por clivagem do éster sulfito ou por declorinação, onde os isômeros, $\alpha$ e $\beta$-endosulfan, produzem endosulfan diol e pequenas quantidades de endosulfan éter, hidroxiendosulfan éter e endosulfan lactona (Lehr, 1993). O metabólito endosulfan sulfato não sofre fotólise e não se forma nestes processos fotoquímicos. 
De acordo com Goebel et al. (1982) a atividade inseticida do endosulfan é reduzida pela fotodecomposição. Esta perda de atividade é explicada pela conversão até compostos mais polares, cuja penetração no inseto é conseqüentemente diminuída.

Segundo Goebel et al. (1982), somente o $\alpha$-endosulfan sofre a descloração fotoquímica ao nível da dupla ligação por deshalogenação redutiva, enquanto que o isômero beta permanece inalterado.

Segundo Roberts \& Hutson (1999) o endosulfan é rapidamente hidrolizado ao endosulfan diol, mas é moderadamente persistente em solo onde é convertido ao sulfato, que é altamente persistente. $\mathrm{O}$ endosulfan sulfato é também o principal metabólito em plantas e ocorre como um metabólito em alguns mamíferos. Outros metabolismos incluem o diol e muitos produtos gerados por oxidação do diol: éter, hidroxi-éter e a lactona. Nestes metabólitos, o resíduo clorado permanece inalterado, mas pode ser susceptível a declorinação por microrganismos.

De acordo com Roberts \& Hutson (1999) os isômeros $\alpha$-endosulfan e $\beta$ endosulfan são degradados no solo com valores de $\mathrm{DT}_{50}$ de 30 a 70 dias, respectivamente. O principal metabólito é usualmente o sulfato cíclico que é degradado mais lentamente que o original. Em estudos de campo, o $\mathrm{DT}_{50}$ para o endosulfan total ( $\alpha$-endosulfan e $\beta$-endosulfan e endosulfan sulfato) variaram de 5 a 8 meses.

Sob condições subtropicais, quando o endosulfan foi aplicado em solo arenoargiloso, a volatilização foi a principal rota de dissipação. A dissipação foi ocasionada pela conversão ao endosulfan sulfato e o diol, sendo a persistência do sulfato maior que 238 dias, enquanto que o diol foi dissipado quase que totalmente dentro de 28 dias (Kathpal et al., 1997).

O período de semi-decomposição ou meia-vida biológica do endosulfan varia entre 30-100 dias e estes valores são extremamente favoráveis em comparação com os valores de meia-vida para os demais organoclorados (DDT, Heptacloro, Endrin, Toxafeno, Aldrin, Dieldrin, Clordano e BHC) que variam de 365 a 4380 dias (Khan, 1980). 
Com relação à degradação microbiana, Martens $^{1}$ (1976) citado por Miles \& Moy (1979), estudaram extensivamente a degradação do endosulfan em 28 espécies de fungos do solo e 50 espécies de bactérias in vitro por 10 dias. Metade das espécies de fungos formou o endosulfan sulfato e algumas poucas espécies formaram endosulfan diol, enquanto que as bactérias degradaram preferencialmente para o endosulfan diol, o mesmo ocorrendo com os actinomicetos.

Segundo Roberts \& Hutson (1999) o endosulfan em meio de cultura foi degradado por culturas mistas de organismos de solos agriculturáveis, sob condições aeróbicas, sendo identificados o diol, o éter, a lactona e o éter hidroxi. Ambos os isômeros, $\alpha$-endosulfan e $\beta$-endosulfan, incubados com Aspergillus niger originaram o diol. Um microrganismo da família Pseudomonadae também originou o diol, como o maior metabólito.

Segundo Tornisielo \& Silva (1993a) em estudos conduzidos em colunas de lixiviação com ${ }^{14} \mathrm{C}$-endosulfan em solos: Latosssolo Roxo, Latossolo Vermelho Amarelo e Areia Quartzosa, a quantidade lixiviada pode ser considerada relativamente baixa, pois do total do inseticida aplicado permaneceram nos solos 97,8; 86,2 e 93,3\%, respectivamente. Destes percentuais, permaneceram na faixa de 0 a $2 \mathrm{~cm}$ : 73,4; 82,3 e 78,7\%. Estes dados confirmam resultados encontrados em estudos conduzidos por Tornizielo \& Silva (1993b), que demonstraram médio potencial de adsorção em solos Areia Quartzosa e alto no solo Latossolo Vermelho Amarelo.

A despeito de seu grande espectro de ação, é bem tolerado por uma série de insetos benéficos, como predadores, parasitos e abelhas (Brooks, 1976; Huttenbach, 1982), e tem se mostrado efetivo para uma grande variedade de pragas, no caso Hemíptera, Lepidóptera, Homóptera, Coleóptera, Isóptera, Thysanóptera e Orthóptera, que são as de maior importância agrícola, além dos ácaros Eriophydae e Tarsonemidae.

Apesar da proibição do uso de organoclorados na agricultura, através da Portaria 95 de 21/11/1985, o endosulfan teve seu uso liberado, porém restrito às culturas de soja,

\footnotetext{
${ }^{1}$ MARTENS, R. Degradation of [8,9- $\left.{ }^{14} \mathrm{C}\right]$ - endosulfan by microrganisms. Applied and Environmental Microbiology, v.31, p. 853 (1976).
} 
cacau, café e algodão, mediante prescrição do receituário agronômico (Baptista, 1995). E mais recentemente teve seu registro liberado para cana-de-açúcar (Andrei, 1999).

De acordo com a ANVISA (2003) este pesticida apresenta classificação toxicológica I, persistência e degradação média no ambiente, com pequeno deslocamento para regiões vizinhas.

Em se tratando de produto registrado para culturas com amplas abrangências geográficas, até o presente momento este pesticida continua gerando polêmicas sobre sua utilização, dividindo as opiniões em duas vertentes: expressiva toxicidade para organismos aquáticos e a alta eficiência no controle de pragas, bem como a seletividade a insetos benéficos, sendo muito utilizado no manejo integrado de pragas (MIP).

O grande aumento no uso de pesticidas é um dos meios para atingir a expansão necessária para a produção suficiente de alimentos para a população e produtos de interesse, como combustível, por outro lado pode resultar no aumento de contaminação dos alimentos e do ambiente.

Dentro das boas práticas agrícolas e como parte integrante do programa de racionalização do uso de pesticidas, tem-se o manejo integrado de pragas (MIP), que por implicar diretamente em reduções do custo de produção, da poluição ambiental, dos riscos de intoxicações e dos níveis de resíduos em alimentos, vem ganhando espaço junto aos agricultores.

Para minimizar a contaminação de resíduos no ambiente é necessário restringir o uso dos pesticidas mais persistentes, ou utilizar técnicas que visem acelerar os processos de degradação destes no ambiente.

\subsection{Adjuvantes}

Os espalhantes adesivos são surfactantes não iônicos largamente utilizados como adjuvantes na aplicação de pesticidas. Os óleos vegetais vêm sendo empregados como espalhantes adesivos, em substituição aos óleos minerais. Quando misturados às moléculas de pesticidas, criam uma barreira de proteção, proporcionando redução nas 
perdas que podem ser causadas por: hidrólise, fotodegradação, volatilização, perdas por deriva e lavagem de parte área das plantas por águas pluviais, melhorando o desempenho de inseticidas, fungicidas e herbicidas. A formulação de pesticidas, com diluentes à base de óleos vegetais, deve ser considerada na busca de técnicas que visem, melhorar a eficiência, racionalizar o uso do controle químico e minimizar contaminações ambientais.

Outro fato de grande importância é a possibilidade do uso de produtos com óleo de soja, como coadjuvante na aplicação de pesticidas, principalmente em culturas perenes ou em culturas anuais de ciclo longo, como é o caso da cana-de-açúcar, proporcionando um incremento na eficiência no controle de pragas de solo.

Outra aplicação é a utilização em solos arenosos, como é o caso dos solos do cerrado e Nordeste, que devido ao baixo teor de matéria orgânica e argila proporcionam baixa adsorção, permitindo que o pesticida lixivie, contaminando águas subterrâneas. Com o crescente avanço da fronteira agrícola, o plantio nestas áreas pode representar um poluidor em potencial do ambiente.

Dentre as principais reações envolvidas nos processos de transformação está a oxidação de pesticida, uma das mais importantes e básicas dentre as reações metabólicas, que ocorre freqüentemente em microrganismos.

De acordo com Lawson (1995), os óleos naturais e gorduras de origem vegetal contêm substâncias capazes de inibir a oxidação. Dentre os antioxidantes universalmente distribuídos, o $\alpha$-tocoferol é o mais importante, abundante e ativo isômero, mas em adição a esta vitamina, três outros tocoferóis com atividade biológica são encontrados nos alimentos: $\beta$-, $\gamma$ - e $\delta$ - tocoferol

Segundo Farrell \& Roberts (1994), o óleo de soja contém predominantemente $\gamma$ tocoferol (59,30 mg/ 100g) com quantidades menores de $\delta$-tocoferol (26,4 mg/ 100g) e somente uma quantidade relativamente pequena de $\alpha$-tocoferol (10,1 mg/100 g). Recentemente, determinações do potencial bioquímico de antioxidante in vitro têm produzido valores tão alto quanto 68 a $100 \%$ para $\gamma$-tocoferol. 
Com relação a atuação dos óleos sobre a inibição de processos oxidativos, estudos antigos efetuados com óleo de gergelim, mostraram a inibição no processo de epoxidação de ciclodienos (O’Brien, 1967).

Em estudo mais recente realizado por Lentza-Rizos \& Avramides (1991) com resíduos de inseticidas organofosforados em óleo de oliva, observou-se que o composto original fention foi o mais importante resíduo em amostras frescas, evidenciando a inibição da degradação por oxidação, enquanto que uma alta quantidade do metabólito fention sulfóxido foi verificado em amostras avaliadas somente após 104 dias.

De acordo com os resultados obtidos em estudos de avaliação dos níveis residuais de endosulfan em amostras de grãos, óleo e vagens de soja, verificou-se que o produto não sofreu degradação microbiana, devido à ausência do metabólito endosulfan sulfato, evidenciando que algum mecanismo estaria inibindo o processo de oxidação (Corrêa, 1999).

Agro-adjuvantes tais como, óleos vegetais são mais biodegradáveis, fontes renováveis e materiais de menores custos. Novos adjuvantes devem ser mais eficientes, atóxicos, ter menor impacto ambiental no ambiente e maximizar a atividade de pesticidas. No entanto, pesquisas não devem ser ignoradas para investigar o metabolismo e modo de ação de adjuvantes por si, seus efeitos fisiológicos em plantas e seus papéis na formulação e aplicação de pesticidas (Chow \& Grant, 1992).

Foy (1992) estudou a lixiviação dos herbicidas: dicamba (altamente móvel), atrazina (intermediário) e clorprofan ou trifluralina (relativamente imóveis) em dois tipos de solos: orgânico (80\% de matéria orgânica) e outro com textura arenosa utilizando colunas e placas de TLC. Os surfactantes, em altas concentrações notoriamente aumentam a mobilidade dos herbicidas, no entanto o autor verificou que os surfactantes aniônicos (Sulfato de lauril sódio), não-iônicos (Hyamina 1622) e catônicos (Tween-80) testados causaram efeitos variáveis no movimento dos herbicidas, dependendo da dose e tipo de solo.

O efeito do SoyOil 937 (óleo de soja 93,7\% e 6,3\% de emulsificante) foi avaliado nas características físicas no controle de Cercospora arachidicola e Sclerotinia minor em amendoim por clorotalonil e iprodione, respectivamente. O SoyOil 937 em 
concentrações de 0,5 e $1 \%$ do volume pulverizado aumentou significativamente o controle da mancha foliar controlada com o clorotalonil $(1,26 \mathrm{~kg} / \mathrm{ha})$ e foi significativamente melhor que o fungicida aplicado sozinho. A eficácia do iprodione não foi afetada pelo uso do SoyOil 937 (Cu et al., 1992).

Segundo Nakano (1969) em estudo de comportamento de inseticidas orgânicosintéticos quando adicionados de espalhantes adesivos como, Novapal, AG-BEM, Triton X-114, Citowett, Sandovit e Esapon, observou-se que a atuação dos inseticidas sistêmicos testados: metasystox, phosdrin, bidrin e vamidathion foi a mesma na presença e ausência do espalhante. Inseticidas com ação de ingestão como, diazinon, sevin, DDT e dipterex, na formulação pó molhável e inseticidas como endrin e gusathion metílico na formulação concentrado emulsionável não apresentaram diferenças estatísticas na presença e ausência dos espalhantes adesivos. Inseticidas de ação de contato, malathion e de ação de profundidade, fenthion não apresentaram melhor eficiência e maior efeito fumigante com a adição do espalhante.

\subsection{Transformação de pesticidas}

Segundo Lavorenti (1997), o comportamento dos pesticidas no solo é complexo por haverem numerosas interações entre as fases sólidas, líquidas e gasosas.

A avaliação dos processos de retenção, transporte e transformação de produtos químicos é de relevante importância, pois permite conhecer a persistência dos mesmos no ambiente.

Segundo Bollag \& Liu (1990) uma vez introduzidos no ambiente, os pesticidas e outros poluentes antropogênicos estão sujeitos aos processos de transformação biológica e não biológica. Entre os processos biológicos, o metabolismo microbiano é a principal forma na transformação de pesticidas ou degradação. De fato tem sido estabelecido que, em muitos casos, microrganismos são mais importantes na degradação de um pesticida que os mecanismos físico-químicos (Munnecke et al., 1982). A importância de microrganismos é esperada devido à diversidade e singularidade de suas atividades metabólicas capacitadas para prosperar nos nichos ecológicos que são em muitos casos inabitáveis. Os microrganismos são agentes chaves na degradação de uma vasta gama de 
moléculas de pesticidas orgânicos nos ecossistemas aquáticos e terrestres, envolvendo processos aeróbicos, anaeróbicos e metabolismo quimilitotróficos, fermentação, metabolismo via enzimas extracelulares. Alguns pesticidas, no entanto, são resistentes à degradação microbiana e persiste por um período maior no ambiente. Outros somente são transformados a produtos intermediários, ocasionalmente de maior toxicidade.

No entanto para determinar o potencial recalcitrante ou a toxicidade de pesticidas e seus metabólitos, é essencial obter conhecimentos básicos da ação dos microrganismos e o destino dos pesticidas individualmente. Somente então se torna possível trabalhar sobre a resolução dos problemas da poluição de pesticidas.

Esta transformação também é conhecida como degradação, a qual consiste em desdobrar a estrutura molecular do pesticida, em componentes menores ou mais simples por meios bióticos ou abióticos. Estes subprodutos resultantes tendem a diminuir a toxicidade da molécula do pesticida, embora possa, ocasionalmente, resultar em componentes mais tóxicos do que a molécula original.

O agente de decomposição microbiana é regulado enzimaticamente, pois é dependente da ação catalítica de enzimas específicas produzidas pelos microrganismos. As enzimas são compostos orgânicos complexos que aceleram as reações químicas, sem se tornar parte dos produtos finais e governam as reações de degradação dos pesticidas e tem como função complexar nutrientes para as células microbianas.

Quando um pesticida é aplicado ao solo, isso causará um ajuste na população microbiana presente. Quando os microrganismos capazes de degradar esses produtos já estiverem presentes no solo tratado ocorrerá um período denominado lag que pode variar de uma a duas semanas, no qual a concentração do pesticida não será alterada. Durante esse período, os organismos multiplicam-se rapidamente, pois utilizam os pesticidas como fonte de energia. Quando a população está suficientemente grande, o ataque às moléculas de pesticidas faz com que a concentração do produto se reduza e quando essa diminui a um nível abaixo daquele necessário para que o produto tenha atividade, diz-se que este foi inativado.

Segundo Moreira \& Siqueira (2002) quando se busca entender o impacto dos pesticidas sobre o solo e seus processos se faz necessária uma avaliação criteriosa e 
holística envolvendo todas as interações bióticas e abióticas. Apesar deste cenário complexo, evidências científicas disponíveis permitem afirmar que: “desde que os pesticidas sejam aplicados seguindo-se rigorosamente as recomendações técnicas, seus efeitos ecológicos e funcionais na comunidade microbiana do solo, são geralmente temporários”.

A decomposição dos pesticidas e de seus sub-produtos continua indefinidamente até que eles sejam reduzidos a dióxido de carbono, água e elementos básicos, como nitrogênio, enxofre, fósforo e outros.

É de extrema importância na degradação de uma molécula de pesticida saber a maneira como ela se degrada e a taxa na qual ela se degrada, as quais têm influência na persistência da molécula no meio ambiente. Esta persistência tem ligação direta com a eficácia do pesticida, podendo resultar na presença indesejável de seus resíduos no meio ambiente.

De acordo com Frehse \& Anderson (1983), a taxa de metabolismo de pesticidas no solo é função de três variáveis consideradas chaves:

a) a disponibilidade dos produtos aos microrganismos ou aos sistemas enzimáticos;

b) a quantidade desses microrganismos ou dos sistemas enzimáticos;

c) o nível de atividade desses microrganismos ou desses sistemas enzimáticos.

A composição e distribuição dos átomos nas moléculas de pesticidas definem as propriedades físico-químicas e biológicas, portanto também a disponibilidade destes produtos à ação de microrganismos (Lavorenti, 1997).

No ambiente onde os pesticidas são aplicados há, geralmente, diferentes tipos de microrganismos, sendo que os principais encontrados no solo são as bactérias e os fungos. Esses organismos são capazes de transformar as moléculas, levando à sua inativação, assim como completa mineralização até $\mathrm{CO}_{2}, \mathrm{H}_{2} \mathrm{O}, \mathrm{NO}_{3}{ }^{-}$, etc.

Nos solos, a maioria das atividades metabólicas ocorre na região das raízes das plantas. Os microrganismos são capazes de degradar uma grande variedade de produtos químicos, de simples polissacarídeos a aminoácidos, proteínas e lipídeos, a materiais mais complexos tais como, resíduos de plantas. Sendo capazes de degradar vários 
pesticidas, com maior ou menor rapidez, dependendo principalmente da composição química dos mesmos (Lambais, 1992).

A transformação microbiana de um pesticida pode envolver mais que um tipo de mecanismo e sob diferentes condições vários produtos podem ser derivados de um mesmo composto inicial, dependendo dos parâmetros ambientais. O processo de transformação pode ser mediado por um organismo ou pode ser resultado do efeito combinado de vários organismos.

De acordo com Bollag \& Liu (1990), os principais processos envolvidos no metabolismo microbiano de pesticidas são oxidação, redução, hidrólise e reações sintéticas. A oxidação de pesticidas que ocorre freqüentemente em microrganismos é uma das mais importantes e básicas reações metabólicas. As enzimas envolvidas em reações de oxidação de pesticidas estão relacionadas com vários grupos de enzimas oxidativas conhecidas, tais como as peroxidases e oxidases de múltiplas funções. As seguintes reações oxidativas podem ser observadas:

\section{a. Hidroxilação}

A hidroxilação microbiana é freqüentemente a primeira etapa da degradação de pesticidas. A adição de um grupo hidroxil dentro de uma molécula de pesticida faz o composto ser mais polar e, portanto, mais solúvel em água, tornando a substância biologicamente mais ativa. As enzimas catalizadoras desta reação são hidroxilases, monoxigenases ou oxidases de múltiplas funções. A hidroxilação pode ocorrer em anéis aromáticos e grupos alifáticos. Em todos os casos, o oxigênio molecular e o NADPH são necessários no arranjo das oxigenases de múltiplas funções para disponibilizá-las para atacar o composto.

b. N-dealquilação

A N-dealquilação é uma significativa reação de detoxificação de pesticidas feniluréias, acilanilidas, carbamatos, s-triazinas, dinitroanilinas e bipiridil. Substituições alquil nas moléculas aromáticas são freqüentemente o primeiro local, onde os microrganismos iniciam a transformação catabólica de uma molécula xenobiótica. A enzima envolvida é uma oxidase de múltipla função. 
c. $\beta$ - oxidação

Muitos pesticidas aromáticos, especialmente herbicidas fenoxialcanoatos, que tem ácidos graxos na superfície da cadeia, podem ser metabolizados por $\beta$-oxidação. Esta reação ocorre através de clivagem de fragmentos de dois carbonos de um ácido graxo; a cadeia de ácido graxo diminuída pode ser ainda degradada da mesma maneira até cadeias de quatro ou dois carbonos. Substituição no anel aromático de um $\omega$ fenoxialcalóide ou especialmente na cadeia lateral tem uma forte influência na $\beta$ oxidação.

Para o funcionamento normal da $\beta$-oxidação, dois prótons são requeridos em ambos os carbonos $\alpha$ e $\beta$.

\section{d. Decarboxilação}

O reposicionamento de um grupo carboxil pelo $\mathrm{H}$ é outra reação enzimática comum realizada pela atividade microbiana. No caso de ácidos carboxílicos alifáticos, o grupo carboxil pode ser mais ou menos prontamente degradado dependendo da influência da configuração e substituintes da molécula. A decarboxilação é uma reação catalisada por microrganismos de larga expansão para compostos que ocorrem naturalmente, e vários exemplos têm sido detectado no metabolismo de pesticidas. Muitas indicações de carboxilação causadas pela microflora do solo foram encontradas com herbicidas ácidos benzóicos, bipiridilas, e acaricidas hidrocarbonetos clorados.

e. Clivagem da ligação de éter

A clivagem de ligações de éter em pesticidas pode diminuir significativamente sua toxicidade para organismos alvos. Em tal clivagem, a separação de hidrocarbono de um átomo de oxigênio, que funciona para ligá-lo com outra molécula é, portanto, importante no estudo da transformação microbiana de pesticida. No entanto, o mecanismo específico desta reação ainda não é bem elucidado. Estudos sugerem que a clivagem seja catalisada por oxidases de múltiplas funções na presença de nucleotídeos 
piridinas reduzidas e molécula de oxigênio. O-dealquilação também representa reação de clivagem de éter, na qual somente um grupo alquil é removido como opositor a grupos moleculares extensos.

Muitos pesticidas, tais como herbicidas de ácido benzóico, organofosforados, carbamatos, metoxi-s-triazinas, feniluréias e fenoxyalcanoatos, tem sua ligação ou um grupo alcoxi. A clivagem de uma ligação de éter foi investigada particularmente com os herbicidas fenoxialcanoicos que produzem os fenóis correspondentes como intermediários.

\section{f. Epoxidação}

A epoxidação é uma inserção de um átomo de oxigênio dentro de uma dupla ligação carbono-carbono, freqüentemente resulta na formação de produtos com grande toxicidade ambiental. Muitos microrganismos podem catalisar a reação de inseticidas ciclodienos clorados, aldrin, endosulfan, isodrin e heptaclor para seus epóxidos tóxicos derivados. Vários pesquisadores constataram que microrganismos tais como: Aspergillus niger, A. flavus, Penicillium chrysogenum, P. notatum, Rhizopus, Trichoderma e Fusarium podiam promover a epoxidação.

\section{g. Ligação oxidativa}

A ligação oxidativa ou reações de condensação são catalizadas por fenol oxidases, tais como: lacases e peroxidases. Na ligação oxidativa de fenol, por exemplo, ariloxil radicais fenolatos são formados pela remoção de um elétron e um próton do grupo hidroxil. Os radicais fenolatos resultantes então se ligam com compostos fenólicos ou outros para produção de produtos polimerizados ou dimerizados. Este processo, importante durante a formação de húmus, apresenta ligações junto com compostos reativos através de reações enzimáticas, resultando em uma mistura complexa de moléculas polimerizadas. Em particular, produtos de degradação fenólica de ligninas produzidas por fungos e outros microrganismos reagem entre eles com aminoácidos, peptídeos e com compostos de pesticidas possuindo grupos funcionais similares. 
h. Clivagem de anel aromático

A maioria dos pesticidas orgânicos tem um ou mais anéis aromáticos e conseqüentemente, seu catabolismo somente é possível se ocorrer a clivagem do anel. Enquanto numerosos microrganismos, especialmente bactérias, foram isolados devido à capacidade de clivar o anel benzênico, muitos pesticidas aromáticos com substituições diversas e múltiplas são, com freqüência, completamente resistentes ao ataque de microrganismos, dependendo da configuração molecular particular. O tipo de ligação, o substituinte específico, sua posição e seu número determinam a suscetibilidade para a fissão de um anel aromático. Mesmo que certas generalizações afetem prováveis mecanismos de decomposição podemos ter forte resistência à degradação através do incremento de substituições halogenadas, ou degradações mais lentas de moléculas substituídas na posição meta, quando comparada às posições orto ou para. Cada pesticida tem que ser investigado independentemente para compreender e avaliar a probabilidade da clivagem microbiana de anel aromático.

\section{i. Clivagem de anel heterocíclico}

Semelhante aos compostos com moléculas carbocíclicas aromáticas, aquelas com anel heterocíclico estão sujeitas à degradação por microrganismos. Estes compostos heterocíclicos, no entanto tem atraído menos atenção devido à dificuldade em rastrear seus metabólitos intermediários. Em pesticidas com tais anéis heterocíclicos, o mecanismo seguido pelo processo de degradação é complicado pelos heteroátomos, usualmente $\mathrm{N}$, $\mathrm{O}$ e $\mathrm{S}$, no qual contribui com características individuais às reações de decomposição.

\section{j. Sulfoxidação}

A reação de sulfoxidação implica na conversão enzimática de um composto bivalente para um sulfóxido e ocasionalmente uma sulfona.

A oxidação de tioéteres e sulfitos ao sulfóxidos e sulfatos correspondentes pode ser catalisada por minerais. Freqüentemente é difícil distinguir entre uma reação química 
e biológica. A observação de uma reação de sulfoxidação em solo não pode ser atribuída à atividade microbiana sem o estabelecimento que a catálise é realmente de origem biológica.

De acordo com Sala et al., (2000), a biodiversidade global está mudando muito, às taxas sem precedentes, como uma resposta complexa às muitas alterações antropogênicas em todo o ambiente. A magnitude desta mudança é tão grande e tão fortemente ligada aos processos dos ecossistemas e o uso da sociedade dos recursos naturais, que a alteração da biodiversidade é agora também considerada como importante mudança global. Na definição de biodiversidade, estão todos os organismos terrestres e aquáticos, incluindo plantas, animais e microrganismos a escalas da diversidade genética dentro da população, para diversidade de espécies; diversidade de comunidade dentro das diferentes paisagens.

Quando se fala em biodiversidade e extinção de espécies a mídia se refere às espécies vegetais e animais que vivem acima do solo. As comunidades de organismos micro e macroscópios que habitam o solo, por não estarem visíveis aos olhos humanos, raramente são mencionadas e por isso, negligenciadas. No entanto, essas comunidades “invisíveis”, principalmente os microrganismos, realizam atividades imprescindíveis para a manutenção e sobrevivência das comunidades vegetais e animais. No solo, as atividades principais dos organismos são: decomposição da matéria orgânica, produção de húmus, ciclagem de nutrientes e energia, fixação de nitrogênio atmosférico, produção de compostos complexos que causam agregação do solo, decomposição de xenobióticos e controle biológico de pragas e doenças. Com base em seu tamanho, a biota do solo pode ser classificada em microrganismos, micro, meso e macrofauna (Moreira \& Siqueira, 2002).

No âmbito de ciclagem de nutrientes, um aspecto relevante e de suma importância é que o uso excessivo de pesticidas, de forma não racional, pode acarretar em perda da bioviversidade da microbiota do solo, levando à seleção de algumas espécies de microrganismos que consigam efetuar a degradação de produtos, 
principalmente quando este uso está associado à aplicação do mesmo ingrediente ativo por repetidas vezes sem rotacionar com outros pesticidas.

Enquanto a contribuição dos fatores abióticos na agregação do solo aumenta com a diminuição da granulometria das partículas do solo, a dos bióticos diminui. Portanto, em solos argilosos a contribuição dos microrganismos é geralmente pequena. Todos os grupos de microrganismos atuam nesse processo, porém de modo muito diferenciado. Em geral, a ação dos microrganismos decresce na seguinte ordem: fungos $>$ actinomicetos $>$ bactérias produtoras de polissacarídeos extracelulares $>$ leveduras $>$ maioria das bactérias (Moreira \& Siqueira, 2002).

A presença de um microrganismo em determinado solo é função das condições ambientais dominantes e dos limites da sua bagagem genética. O sucesso de um organismo em qualquer habitat é função da extensão e rapidez de suas respostas fisiológicas às condições ambientais predominantes. Algumas espécies de microrganismos podem sobreviver em condições extremas de salinidade, temperatura, pressão e pH. Além disso, os microrganismos, de modo geral, são bastante versáteis em adaptar-se às mudanças ambientais. Limitações físicas (e.g. água, aeração, porosidade, adesão) e químicas (e.g. disponibilidade de nutrientes e toxicidade de elementos como metais pesados) aos microrganismos podem ocorrer nos solos, mas muitas espécies são capazes de adaptar a essas condições (Moreira \& Siqueira, 2002).

De acordo com Janhel (1997) para muitos microrganismos, as melhores condições de desenvolvimento ocorrem em solos arenosos, em torno da capacidade de campo e em solos argilosos em torno da metade da capacidade de campo.

O emprego de microrganismos conhecidos no tratamento de rejeitos potencialmente tóxicos, incluindo hidrocarbonetos de petróleo é uma prática habitual em alguns países desenvolvidos. Em estudo de biorremediação realizado em solos impactados por óleo cru, que corresponde à fração líquida do petróleo, cuja composição é de hidrocarbonetos alifáticos e aromáticos, compostos sulfidrilados, oxigenados e nitrogenados, e alguns metais dissolvidos em água, utilizando fungos filamentosos, mostraram que dentre os fungos avaliados o gênero Aspergillus apresentou a maior eficiência de degradação do petróleo (Macedo et al., 2002). 
O gênero Aspergillus pertence à divisão Deuteromycota, também chamados fungos imperfeitos por causa da falta da fase sexual. Os fungos são organismos quimiorganotróficos, cuja principal função no solo é a decomposição de resíduos orgânicos. Os quimiorganotróficos, que utilizam energia química e substâncias orgânicas como fonte de carbono e elétrons, são os mais abundantes no solo em densidade e diversidade. As bactérias nitrificadoras são quimiolitotróficos. A quimiolitotrofia é a habilidade de usar energia de compostos inorgânicos, compreende diversas reações inorgânicas relacionadas a processos edáficos importantes como desnitrificação, a nitrificação, a metagênese e a capacidade de crescer utilizando compostos de enxofre reduzidos (Moreira \& Siqueira, 2002).

O uso intensivo de pesticidas ou uso de produtos cada vez mais eficientes, faz surgir a preocupação do homem em estudar o comportamento e destino final destes xenobióticos no solo, onde existe uma comunidade microbiana atuando sobre os mesmos, além de outros fatores ambientais, com a finalidade de mitigar os efeitos nocivos.

Desempenhando um papel importante na quebra e transformação biótica de matéria orgânica em solos férteis, os microrganismos, com muitas espécies contribuem para os diferentes aspectos da fertilidade do solo. Interferências de longo prazo com estes processos bioquímicos poderiam afetar potencialmente a ciclagem de nutrientes e até alterar a fertilidade do solo. Transformação do carbono e nitrogênio ocorre em todos os solos férteis, mesmo que as comunidades microbianas responsáveis por estes processos sejam distintas de solo para solo, os caminhos de transformação são essencialmente os mesmos (OECD, 2000a; OECD, 2000b).

Estudos de biodegradabilidade em solos fornecem dados de taxa e extensão de biodegradação aeróbica (mineralização), que é a propriedade dos pesticidas serem metabolizados por organismos no ambiente através da conversão de um elemento de uma forma orgânica para uma forma inorgânica. Uma alta biodegradabilidade fornece evidências de que o pesticida será mineralizado em solos naturais (OECD, 1999).

Respiração é um dos mais antigos parâmetros para quantificar a atividade microbiana. Ela representa a oxidação da matéria orgânica por organismos aeróbios do 
solo, que, portanto utilizam $\mathrm{O}_{2}$ como aceptor final de elétrons até $\mathrm{CO}_{2}$. Assim ela pode ser avaliada tanto pelo consumo de $\mathrm{O}_{2}$ como pela produção de $\mathrm{CO}_{2}$. A determinação do $\mathrm{O}_{2}$ pode ser feita por cromatografia gasosa ou eletrorespirômetro e a do $\mathrm{CO}_{2}$ por titulação ou condutividade elétrica, cromatografia gasosa, espectroscopia de infravermelho (IRGA) ou por ${ }^{14} \mathrm{C}$, neste último caso quando se deseja monitorar compostos orgânicos específicos. Pode-se medir a respiração basal da amostra (com a matéria orgânica pré-existente) ou com indução por substrato, adicionando-se uma fonte orgânica específica prontamente disponível, como por exemplo, a glicose. Durante a decomposição, parte do carbono e nutrientes fica retida na biomassa que é rica nesses elementos. A quantidade de carbono residual que fica na biomassa depende da degradabilidade do substrato. Esta geralmente varia de 20 a $40 \%$ do C dos substratos prontamente assimiláveis, no período de 8 a 12 semanas de decomposição, sendo esta proporção bem menor para os substratos com baixa degradabilidade, cuja proporção de C que vai para a biomassa neste caso é muito pequena. Através dos mecanismos bioquímicos específicos os componentes individuais do resíduo são mineralizados transformando-se em $\mathrm{CO}_{2}$, que é liberado para a atmosfera (Moreira \& Siqueira, 2002).

A bioquímica do solo é fundamentada em três processos principais, resultantes do crescimento e da atividade microbiana do solo, representados por: a) um fluxo de elétrons, que dependendo das condições de oxi-redução tem como aceptor final o $\mathrm{O}_{2}$ (aerobiose) ou formas inorgânicas de N, S, C e metais oxidados ou compostos orgânicos de cadeia curta (anaerobiose); b) um fluxo de carbono que gera $\mathrm{CO}_{2}, \mathrm{CH}_{4}$, componentes celulares (biomassa) e produtos orgânicos intermediários para a biossíntese e c) um fluxo de energia na forma de ATP, que sustenta o anabolismo para a produção de biomassa e as funções celulares (Moreira \& Siqueira, 2002).

No fluxo e a dinâmica dos nutrientes, via matéria orgânica do solo, os elementos presentes nos resíduos são utilizados pelos fungos, bactérias, actinomicetos e microfauna, que interagem intensamente como, cometabolismo e relações diversas como, antagonismo e predação através de sucessões tróficas. Através dos mecanismos bioquímicos específicos os componentes individuais do resíduo são mineralizados transformando-se em $\mathrm{CO}_{2}$, que é liberado para a atmosfera. Esse processo é conhecido 
como respiração do solo, respiração edáfica, que se relaciona de modo muito estreito com a disponibilidade de nutrientes (mineralização) e a atividade enzimática, sendo um bom indicador da qualidade do solo.

\subsubsection{Metodologias para análise de dióxido de carbono $\left(\mathrm{CO}_{2}\right)$}

Existem algumas metodologias distintas descritas na literatura para determinação de $\mathrm{CO}_{2}$.

A influência dos pesticidas na atividade biológica do solo como um todo, pode ser estudada através da produção de $\mathrm{CO}_{2}$ pela população microbiana do solo. Bartha \& Pramer (1965) introduziram o respirômetro para avaliação do efeito do pesticida na atividade biológica do solo.

$\mathrm{Na}$ determinação do $\mathrm{CO}_{2}$ por titulometria, o substrato é incubado em frasco hermeticamente fechado. De acordo com metodologia citada por Janhel et al., (1997), após o período de incubação, o $\mathrm{CO}_{2}$ produzido é absorvido pela solução de $\mathrm{NaOH}$, que recebe uma solução de cloreto de bário $\left(\mathrm{BaCl}_{2}\right)$ que impede que o $\mathrm{Na}_{2} \mathrm{CO}_{3}$ ou $\mathrm{NaHCO}_{2}$, formado seja desdobrado em $\mathrm{NaOH}+\mathrm{CO}_{2}$ novamente, quando da titulação com $\mathrm{HCl}$, formando $\mathrm{BaCO}_{3}$ que precipita. A soda que não reagiu com o $\mathrm{CO}_{2}$ é titulada com $\mathrm{HCl}$, sendo a fenolftaleína utilizada como indicador.

A quantificação do $\mathrm{CO}_{2}$ produzida pode ser feita por Injeção em Fluxo Contínuo (Flow Injection Analysis - FIA), como descrito por Jardim et al. (1990) e Kawazaki et al. (2000). Segundo estes autores, o método se baseia na injeção de volume selecionado de amostra no sistema, após a confluência com solução de $\mathrm{H}_{2} \mathrm{SO}_{4}$, desprende $\mathrm{CO}_{2}$. O gás desprendido é separado através de membrana semipermeável (Teflon ${ }^{\circledR}$ ) dissolvendo-se em água destilada e degaseificada formando $\mathrm{H}_{2} \mathrm{CO}_{3}$. A concentração de $\mathrm{CO}_{2}$ é determinada pela condutividade elétrica da solução.

Segundo Rodella \& Saboya (1999), o $\mathrm{CO}_{2}$ pode ser diretamente quantificado através de condutivímetro. Quando o $\mathrm{CO}_{2}$ é absorvido dentro de uma solução alcalina, os íons $\mathrm{OH}^{-}$são consumidos e os íons $\mathrm{CO}_{3}{ }^{-2}$ com menor mobilidade são produzidos, que causa a diminuição da condutividade elétrica. 


\subsubsection{Metodologias para análise de nitrato $\left(\mathrm{NO}_{3}{ }^{-}\right)$}

Os microrganismos do solo mantêm a fertilidade do solo através de múltiplas funções, entre elas, a nitrificação e a degradação de moléculas complexas.

Segundo Vinten \& Smith (1993) a mineralização é o processo pela qual, compostos orgânicos no solo quebram para liberar o íon amônio, $\mathrm{NH}_{4}{ }^{+}$, com a conseqüente liberação de carbono na forma de $\mathrm{CO}_{2}$.

Segundo Odum (1988), as bactérias quimiossintéticas Nitrossomonas convertem a amônia em nitrito e Nitrobacter convertem nitrito em nitrato, obtendo energia da decomposição química.

A avaliação do nitrato significa a completa transformação do nitrogênio pelo processo de nitrificação que é a oxidação do íon amônio para nitrito e a oxidação do nitrito para nitrato.

A determinação de nitrato pode ser feita por vários métodos como: destilação por Kjeldahl, após a redução para amônia, sistema Flow Injection Analysis (FIA) e espectrofotômetria, onde o nitrato é reduzido a nitrito pela reação com o cádmio e ocorre o desenvolvimento de coloração âmbar. Também podemos ter métodos colorimétricos como: reagente brucina, desenvolvimento de coloração amarela; reagente difenilamina com formação de coloração azul e reagente Griess, com formação de coloração vermelha.

Métodos colorimétricos têm sido extensivamente usados para determinar formas inorgânicas de $\mathrm{N}$ em extratos de solo. Suas vantagens principais são rapidez e conveniência, particularmente quando análises são feitas em um grande número de amostras. Em tais casos, um sistema de análise automatizado pode ser empregado para determinações simultâneas de $\mathrm{NH}_{4}{ }^{+}, \mathrm{NO}_{3}{ }^{-}$e $\mathrm{NO}_{2}{ }^{-}$a taxas acima de muitas centenas de amostras por hora. (Mulvaney, 1996).

A vantagem de se fazer a quantificação por colorimetria em aparelho de alta sensibilidade, como é o caso do espectrofotômetro BIO-RAD Microplate Reader Benckmark, é a possibilidade de se trabalhar em microescala, minimizar a geração de resíduos das análises laboratoriais e conseqüentemente reduzir a contaminação ambiental. 
O princípio do método de brucina citado por Brown et al. (1970) está baseado no fato de que o nitrato reage com a brucina (um alcalóide) em meio ácido, produzindo uma solução com coloração amarela. A cor produzida é proporcional à sua concentração de nitrato na amostra, o que é a base para sua quantificação.

\subsection{Transporte de pesticidas}

O movimento de produtos químicos no solo é um processo muito importante na distribuição e transporte dos mesmos no ambiente. Se o produto apresenta alto potencial de lixiviação, este poderá percolar pelo perfil do solo e contaminar o lençol freático. Portanto, tais informações são fundamentais para prever a distribuição de pesticidas no ambiente.

Segundo Foster et al.(1993), os perfis naturais do solo atenuam ativamente muitos, embora não todos, poluentes da água. O movimento da água na zona nãosaturada é geralmente lento e restrito aos poros menores com uma grande superfície específica. O ambiente químico é normalmente aeróbio e freqüentemente alcalino. Isto resulta em um potencial considerável para:

a) a intercepção, sorção e eliminação de microrganismos patogênicos;

b) a atenuação de metais pesados e outras substâncias químicas inorgânicas, mediante precipitação (como carbonatos, sulfetos ou hidróxidos), sorção ou intercâmbio de cátions;

c) a sorção e a biodegradação de muitos hidrocarbonetos e compostos orgânicos naturais e sintéticos.

A zona biologicamente ativa no solo é constituída efetivamente pela porção mais superficial da zona não-saturada. Muitos dos processos que causam a eliminação e atenuação de poluentes ocorrem de forma mais expressiva nessa zona como resultado de seu conteúdo orgânico, de argila e presença de elevada população bacteriana. Contudo, nem todos os perfis de solos, como nem todas as condições hidrogeológicas são igualmente efetivas para atenuar os poluentes. Ainda mais, o grau de atenuação variará amplamente em uma determinada condição, segundo os tipos e a disposição de contaminantes. No caso de poluentes persistentes e móveis, a zona não-saturada poderá 
apenas induzir um atraso no tempo de chegada à água subterrânea, sem atenuação benéfica alguma. Adicionalmente, a dispersão hidrodinâmica, que acompanha o fluxo de águas subterrâneas, resulta na diluição dos poluentes persistentes e móveis, especialmente na zona saturada dos aqǘferos (Foster et al., 1993).

A preocupação pela poluição das águas subterrâneas se relaciona principalmente com aqüíferos não confinados onde o lençol freático é pouco profundo. Expressivos riscos de poluição podem ocorrer inclusive onde os aqüíferos são semiconfinados ou quando os reservatórios superficiais não possuem a espessura necessária.

Segundo Foster et al., (1993), a apreciação mais lógica, para a definição de risco de poluição das águas subterrâneas, é conceitualizá-la como a interação entre dois fatores semi-independentes:

a) a carga do poluente que é, será ou poderá ser aplicada no solo como resultado da atividade humana;

b) a vulnerabilidade natural à poluição do aqüífero.

O impacto das atividades agrícolas modernas sobre a qualidade das águas subterrâneas tornou-se conhecido em alguns países industrializados durante a década de 70. Em particular, demonstrou-se a existência de altas taxas de lixiviação de nitratos, pesticidas e outros íons móveis em muitos solos submetidos ao contínuo plantio, sustentado por aplicações de grandes quantidades de pesticidas e fertilizantes inorgânicos.

Em algumas zonas áridas, com solos permeáveis, os cultivos de terras, com sistemas ineficientes de irrigação, têm criado, em conseqüência, a recarga do aqüífero. Entretanto, os esforços para reduzir tais perdas diminuirão a dimensão deste recurso e aumentarão sua salinidade. A superirrigação e aplicação de pesticidas e fertilizantes podem causar grandes incrementos no nível freático e resultar numa salinização e contaminação do solo e da água subterrânea.

O uso de grandes quantidades de diferentes pesticidas não tem causado uma expressiva contaminação das águas subterrâneas nos países industrializados, mas há exceções significativas, especialmente em relação, aos compostos mais solúveis e pouco adsorvidos, tais como inseticidas do grupo carbamato e herbicidas do grupo 
carboxiácido e fenilúrea. Esses produtos, mesmo apresentando relativa e rápida biodegradação em solos férteis, têm originado localmente sérios casos de poluição nas águas subterrâneas. Surpreendentemente, têm sido encontradas nas águas subterrâneas concentrações significativas de triazina, um herbicida não-seletivo, embora não a níveis considerados perigosos à saúde humana.

Para um planejamento efetivo do uso da terra é imperativo reconhecer o estreito vínculo entre a prática agrícola e o recurso hídrico subterrâneo, em aspectos de quantidade e qualidade. Uma análise de vulnerabilidade da contaminação do aqüífero deveria indicar aquelas áreas de maior risco, associada a intensa atividade agrícola, envolvendo a possível infiltração de alguns nutrientes, sais e certos pesticidas.

Desse modo, a água passa a ser vista como um recurso estratégico no próximo milênio. A expectativa de que possa faltar água em determinadas regiões do planeta fará com que água se torne a commodity mais disputada nesse século, muito mais que o ouro negro, o petróleo.

A questão consiste em saber se o planeta pode suportar o ritmo atual de exploração dos recursos de água doce. Além disso, se faz necessário ressaltar a questão da equidade de acesso aos recursos hídricos, bem como a salubridade destes recursos que são, freqüentemente, vítimas de diversas formas de poluição, tanto em países de pouca oferta quanto aqueles abundantes em água. A utilização dos recursos de água doce é fonte de numerosos problemas, cuja resolução necessita uma profunda reflexão ética. A água é desperdiçada; seu uso indisciplinado expõe terras frágeis à desertificação; sua disponibilidade e qualidade são determinantes para a estabilidade das gerações futuras (Selborne, 2002).

Segundo Luchini et al., (1984) estudos sobre o comportamento de pesticidas em solos brasileiros revelaram diferenças nos seus movimentos, por apresentarem propriedades físico-químicas distintas.

Existem na literatura alguns métodos propostos para a movimentação vertical de pesticidas no solo, as técnicas de lixiviação e lisímetros são mais adequadas (Tornisielo, 2003). 
A técnica de radioisótopos é particularmente efetiva para avaliar processos de transformação, retenção e transporte por possibilitar processar grande número de amostras, num período curto, além de alta precisão (IAEA, 1983).

$\mathrm{O}$ estudo de mobilidade de produtos químicos radiomarcados $\left({ }^{14} \mathrm{C}\right)$ pode ser realizado em colunas de vidro utilizando solos com características físico-químicas diferentes, submetidas a uma chuva simulada de 200 mm (OECD, 1999).

De acordo com Weber et al. (1994) e Tornisielo (2003) esta técnica por colunas propicia uma boa aproximação das condições do perfil do solo no campo, não exigindo muito espaço, tendo eficiência e custo acessível.

O teste de lisímetros tradicional consiste de monolitos de solo que são extraídos de um local de estudo representativo, recolocado intacto em outro local e usado para estudar a lixiviação de um composto. A utilização de lisímetros vem sendo uma das mais modernas técnicas, pois permite avaliar o sistema solo/água/planta em amostras de solo que não sofreram perturbação das condições mecânicas e biológicas, apresentando uma série de vantagens para o estudo da dinâmica de pesticidas no agroecossistema em comparação a outros métodos, já que simula com exatidão o ambiente de campo e as práticas agrícolas. É mais fácil de monitorar que os experimentos de campo e permite a utilização de radioisótopos, porém exige local específico e exige maiores investimentos, quando comparados à instalação de colunas de lixiviação (Hance \& Führ, 1992 e Tornizielo, 2003).

A mobilidade de produtos químicos no solo pode ser avaliada pela técnica de cromatografia de camada delgada. A técnica é análoga à cromatografia de camada delgada (CCD) convencional, na qual utiliza o solo como fase estacionária, em substituição a sílica gel. O material a ser testado e um controle realizado com 2,4-D, ambos radiomarcados, são aplicados na placa de solo. A placa é colocada em uma cuba de TLC com uma lâmina d’água para eluição e através de revelação com filme raio X é possível determinar o Coeficiente de Mobilidade ( $\mathrm{Rf}=$ Relação de Frente) que é definido como a relação entre a distância percorrida pela substância teste na placa de solo e a distância percorrida pelo solvente $\left(\mathrm{H}_{2} \mathrm{O}\right)$ (IBAMA, 1990). 


\section{MATERIAIS E MÉTODOS}

3.1 Avaliação do efeito do endosulfan no crescimento fúngico de Aspergillus sp (linhagem Cad G1) em meio de cultura na presença e ausência de óleo vegetal.

\subsubsection{Materiais e Equipamentos}

- Placas de Petri

- Erlenmeyer

- Autoclave

- Balança

- Bico de Bunsen

- Extrator Ultraturrax

- Centrífuga

- Cromatógrafo gasoso acoplado a detector de captura de elétrons

- Acetato de etila

- Ciclohexano

- Hexano

- Sulfato de sódio

\subsubsection{Substância teste}

A substância teste utilizada foi o inseticida endosulfan cedido pela Empresa Nortox S.A., que consiste na mistura de dois isômeros, sendo $70 \%$ de $\alpha$-endosulfan e $30 \%$ de $\beta$-endosulfan. 
O inseticida foi utilizado na presença e ausência de óleos vegetais de soja e girassol, sob processos degomado e refinado nas concentrações 0,1 e $0,5 \%$, e presença e ausência de emulsificante, conforme os tratamentos descritos no item 3.1.6.

Cada Erlenmeyer recebeu uma quantidade de endosulfan de $52 \mathrm{mg} / 60 \mathrm{~mL}$, ou seja, 0,867 mg /mL. Para cálculo da dose, considerou-se um volume de calda de 1000 litros /ha e uma dose máxima agronômica de $700 \mathrm{~g}$ de ingrediente ativo endosulfan /ha.

\subsubsection{Preparo do meio de cultura}

Foi preparado um meio mínimo de cultivo para o fungo, conforme descrito no Quadro 1 (Pontecorvo, 1953).

$\mathrm{O}$ pH do meio foi de 6,8. O meio foi autoclavado à pressão de 1 atm por 20 minutos. Foram preparados um volume total de $60 \mathrm{~mL}$ de meio em Erlenmeyer por tratamento e vertidos distribuindo em três placas, ou seja três repetições para cada tratamento.

\begin{tabular}{|ll|}
\hline Reagentes & Quantidade (g) \\
\hline $\mathrm{NaNO}_{3}$ & 9,00 \\
$\mathrm{KCl}$ & 0,75 \\
$\mathrm{MgSO}_{4} \cdot 7 \mathrm{H}_{2} \mathrm{O}$ & 0,75 \\
$\mathrm{KH}_{2} \mathrm{PO}_{4}$ & 2,25 \\
$\mathrm{FeSO}_{4}$ & 0,15 \\
$\mathrm{ZnSO}_{4}$ & 0,15 \\
Glicose/dextrose & 15,00 \\
Agar (Difco puro) & 22,50 \\
Água destilada & 1500 \\
\hline
\end{tabular}

Fonte: Pontecorvo (1953)

Quadro 1. Preparo do meio de cultivo mínimo para crescimento de fungos 


\subsubsection{Sistema teste}

Entre os numerosos gêneros de fungos encontrados no solo, os mais comuns pelo número de espécies ou pela freqüência com que ocorrem, são: Zygorhynchs, Mucor, Rhizopus, Penicillium, Aspergillus, Trichoderma, Fusarium e Cladosporium.

O organismo submetido ao estudo foi o fungo Aspergillus sp (linhagem Cad G1), um dos principais gêneros descritos em literatura na degradação biótica do endosulfan e outros ciclodienos (Bollag \& Liu, 1990; Goebel et al., 1982; Miles \& Moy, 1979).

Cada placa foi inoculada em condições assépticas em três pontos eqüidistantes, conforme pode ser visto na Figura 2.

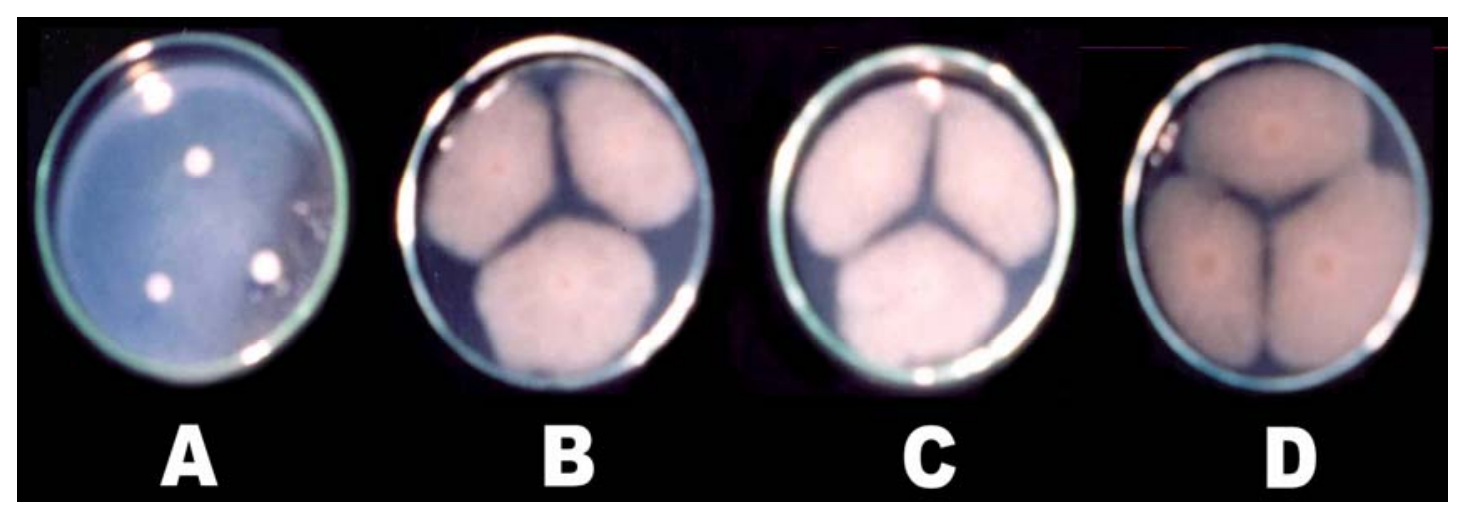

Figura 2 - Comparação dos diâmetros das colônias da linhagem Cad G1 Aspergillus sp, após 6 dias de inoculação para os tratamentos: E+I (A); C+I (B); $\mathrm{OSDu}+\mathrm{E}+\mathrm{I}(\mathrm{C})$ e $\mathrm{OSDu}+\mathrm{EM}+\mathrm{I}(\mathrm{D})$

\subsubsection{Condições de incubação}

As placas foram incubadas a uma temperatura de $37 \pm 0,5{ }^{\circ} \mathrm{C}$, no escuro por um período de 6 dias. As avaliações foram feitas nos dias 2 e 6 .

\subsubsection{Tratamentos}

Os tratamentos utilizados para avaliação estão descritos no Quadro 2. 


\begin{tabular}{|c|c|}
\hline Tratamentos: & Descrição: \\
\hline $\mathrm{C}+\mathrm{I}$ & Meio de cultura + inóculo \\
\hline $\mathrm{C}+\mathrm{OSRu}+\mathrm{I}$ & Meio de cultura + óleo de soja refinado(0,1\%) + inóculo \\
\hline $\mathrm{C}+\mathrm{OSDu}+\mathrm{I}$ & Meio de cultura + óleo de soja degomado $(0,1 \%)+$ inóculo \\
\hline $\mathrm{C}+\mathrm{OGRu}+\mathrm{I}$ & Meio de cultura + óleo de girassol refinado $(0,1 \%)+$ inóculo \\
\hline $\mathrm{C}+\mathrm{OGRu}+\mathrm{I}$ & Meio de cultura + óleo de girassol degomado $(0,1 \%)+$ inóculo \\
\hline $\mathrm{C}+\mathrm{EM}+\mathrm{I}$ & Meio de cultura + emulsificante + inóculo \\
\hline $\mathrm{E}+\mathrm{I}$ & Meio de cultura + endosulfan + inóculo \\
\hline OSDu+E+I & Meio de cultura + óleo de soja degomado $(0,1 \%)+$ emulsificante + endosulfan + inóculo \\
\hline $\mathrm{OSRu}+\mathrm{E}+\mathrm{I}$ & Meio de cultura + óleo de soja refinado $(0,1 \%)+$ emulsificante +endosulfan + inóculo \\
\hline $\mathrm{OGDu}+\mathrm{E}+\mathrm{I}$ & Meio de cultura + óleo de girassol degomado $(0,1 \%)+$ emulsificante + endosulfan+ inóculo \\
\hline $\mathrm{OGRu}+\mathrm{E}+\mathrm{I}$ & Meio de cultura + óleo de girassol refinado $(0,1 \%)+$ emulsificante + endosulfan + inóculo \\
\hline $\mathrm{OSDc}+\mathrm{E}+\mathrm{I}$ & Meio de cultura + óleo de soja degomado $(0,5 \%)+$ emulsificante + endosulfan + inóculo \\
\hline OSRc+E+I & Meio de cultura + óleo de soja refinado $(0,5 \%)+$ emulsificante + endosulfan+ inóculo \\
\hline OGDc+E+I & Meio de cultura + óleo de girassol degomado $(0,5 \%)+$ emulsificante + endosulfan + inóculo \\
\hline $\mathrm{OGRc}+\mathrm{E}+\mathrm{I}$ & Meio de cultura + óleo de girassol refinado $(0,5 \%)+$ emulsificante + endosulfan + inóculo \\
\hline $\mathrm{OSDu}+\mathrm{EM}+\mathrm{I}$ & Meio de cultura + óleo de soja degomado $(0,1 \%)+$ emulsificante + inoculo \\
\hline $\mathrm{OSRu}+\mathrm{EM}+\mathrm{I}$ & Meio de cultura + óleo de soja refinado $(0,1 \%)+$ emulsificante + inóculo \\
\hline $\mathrm{OGDu}+\mathrm{EM}+\mathrm{I}$ & Meio de cultura + óleo de girassol degomado $(0,1 \%)+$ emulsificante + inóculo \\
\hline $\mathrm{OGRu}+\mathrm{EM}+\mathrm{I}$ & Meio de cultura + óleo de girassol refinado $(0,1 \%)+$ emulsificante + inóculo \\
\hline OSDc+EM+I & Meio de cultura + óleo de soja degomado $(0,5 \%)+$ emulsificante + inóculo \\
\hline $\mathrm{OSRc}+\mathrm{EM}+\mathrm{I}$ & Meio de cultura + óleo de soja refinado $(0,5 \%)+$ emulsificante + inóculo \\
\hline OGDc+EM+I & Meio de cultura + óleo de girassol degomado $(0,5 \%)+$ emulsificante + inóculo \\
\hline OGRc+EM+I & Meio de cultura + óleo de girassol refinado $(0,5 \%)+$ emulsificante + inóculo \\
\hline
\end{tabular}

Quadro 2. Descrição dos tratamentos utilizados no experimento de placas. 
Após o término do teste, as placas foram submetidas a um processo de extração em Ultraturrax com $50 \mathrm{~mL}$ de acetato de etila e $10 \mathrm{~g}$ de $\mathrm{Na}_{2} \mathrm{SO}_{4}$ por 2 minutos. O extrato foi centrifugado por 5 minutos. Retirou-se uma alíquota de $10 \mathrm{~mL}$ do sobrenadante que foi evaporada e ressuspendida em $2 \mathrm{~mL}$ da mistura ciclohexano e acetato de etila (1:1) A limpeza da amostra foi realizada em sitema GPC, utilizando como fase móvel a mistura ciclohexano e acetato de etila (1:1) e fase estacionária, duas columas PLGel.

A amostra foi evaporada e ressuspendida em $0,5 \mathrm{~mL}$ de hexano e injetada em cromatógrafo gasoso acoplado a detector de captura de elétrons AGILENT Mod 6890, sob condições MKup- nitrogênio (30 mL/minuto); sistema splitless, coluna HP 608 (0,53 mm de diâmetro, 30 metros de comprimento e 0,5 $\mu \mathrm{m}$ de espessura). Condições de temperatura: injetor $\left(230^{\circ} \mathrm{C}\right)$; detector $\left(320^{\circ} \mathrm{C}\right)$ e coluna com rampa de temperatura $\left(100^{\circ} \mathrm{C}-1\right.$ minuto, $20^{\circ} \mathrm{C} /$ minuto até $280^{\circ} \mathrm{C}$ e $280{ }^{\circ} \mathrm{C}-5$ minutos).

\subsection{Teste de transformação de carbono}

O presente estudo teve como objetivo a avaliação titulométrica do efeito de endosulfan na presença e ausência de óleo de soja na taxa de $\mathrm{CO}_{2}$, através da respiração induzida por glicose em solo Argissolo Vermelho Amarelo (PV).

A titulometria é um método tradicional e simples de se analisar $\mathrm{CO}_{2}$ e citado no EPA (1996), como uma das formas de avaliar teste de toxicidade da comunidade microbiana do solo.

\subsubsection{Materiais e Equipamentos}

- $\quad$ Hidróxido de sódio

- $\quad$ Ácido clorídrico

- $\quad$ Cloreto de bário

- $\quad$ Fenolftaleína

- $\quad$ Glicose

- Ultrassom

- $\quad$ Agitador magnético

- $\quad$ Câmara incubadora 
- $\quad$ Sistema milli-Q

- $\quad$ Termômetro

- $\quad$ Bureta digital

- $\quad$ Micropipeta

- $\quad$ Macropipeta

- $\quad$ Seringa

- $\quad$ Peneira

- $\quad$ Bastão de vidro

- $\quad$ Espátula

- $\quad$ Frasco coletor universal

\subsubsection{Metodologia}

O teste foi conduzido baseado no procedimento descrito na norma da Organization for Economic Co-operation and Development - 216: Soil Microrganism: Carbon Transformation Test, (OECD, 2000a).

Um único solo foi utilizado com as seguintes características: teor de areia: $>50 \%$ e < 75\%; pH: 5,5 a 7,5 e teor de carbono orgânico entre 0,5 e 1,5\% e biomassa microbiana com conteúdo mínimo de $1 \%$ do carbono total do solo, cumprindo-se exigências do protocolo OECD (Tabela 6).

A priori foi conduzido um teste sem a adição da substância teste, endosulfan técnico, com o solo Argissolo Vermelho Amarelo Eutrófico (PV) para validar a metodologia descrita na OECD através da determinação por titulometria com $\mathrm{NaOH}(0,2$ $\mathrm{M})$ e $\mathrm{HCl}(0,1 \mathrm{M})$ para determinar a quantidade de $\mathrm{CO}_{2}$ evoluída a cada duas horas, por um período de exposição de 28 dias e com adição de glicose nos dias 0, 7, 14 e 28.

\subsubsection{Preparo dos tratamentos}

Após a validação da metodologia foram preparados os seguintes tratamentos para o presente estudo: 
B - Branco, frasco sem solo com a armadilha de $\mathrm{NaOH}(0,2 \mathrm{M})$;

C- Controle;

C+O - Controle + Natur'l Oil (0,13 $\mu \mathrm{L}$ de Natur'l Oil/50g);

DMA - Dose máxima agronômica: 700 g de ingrediente ativo endosulfan/ ha (46,7 $\mu \mathrm{g}$ do ingrediente ativo endosulfan/ $50 \mathrm{~g}$ de solo) (Andrei, 1995) e

DMA+O - Dose máxima agronômica: 700 g de ingrediente ativo endosulfan/ha + 2L/ ha de Natur'l Oil (46,7 $\mu$ g do ingrediente ativo endosulfan + 0,13 $\mu \mathrm{L}$ de Natur'l Oil/ 50 g de solo).

O Natur’l Oil é uma mistura comercial de óleo de soja e dispersante, numa proporção 70:30, que vem sendo utilizado em práticas agrícolas, como adjuvante de aplicação de pesticidas e foi selecionado de acordo com os resultados obtidos no teste de placas (item 3.1).

A substância teste sem óleo foi solubilizada com $20 \mu \mathrm{L}$ de acetona p.a., sendo o solvente evaporado e o volume completado com água obtida em Milli-Q até um volume total de $1 \mathrm{~mL}$. Um volume de $0,4 \mu \mathrm{L}$ de Natur'l Oil foi colocado no tratamento DMA+O e completado até o volume total de $1 \mathrm{~mL}$. As soluções foram colocadas em ultrassom por três minutos. Os tratamentos DMA e DMA+O apresentaram como uma suspensão homogênea, mostrando uma forma mais leitosa com a adição do óleo. Foram aplicados $333 \mu \mathrm{L}$ de cada tratamento. Volumes iguais de água e água + Natur’l Oil foram colocados nos controles.

O método adotado neste estudo para avaliação do $\mathrm{CO}_{2}$ está descrito a seguir:

$50 \mathrm{~g}$ de solo seco e passado em peneira de $2 \mathrm{~mm}$ de malha foram pesados e colocados em frasco de vidro hermeticamente fechado de 2,0 L (Figura 3). Foram preparadas três réplicas por tratamento, sendo: solo com glicose; solo sem glicose e branco, frasco sem solo apenas com a armadilha de $\mathrm{NaOH}$.

A umidade do solo foi avaliada. O solo foi reativado com água obtida em Milli-Q e corrigido a $50 \%$ da capacidade de campo. Os frascos foram mantidos em incubadora no escuro a $20 \pm 2{ }^{\circ} \mathrm{C}$ por um período de sete dias. Para cada tratamento foram preparadas três réplicas. 
Após o período de pré-incubação foram adicionados o endosulfan técnico e o Natur'l Oil de acordo com os tratamentos descritos e homogeneizados com bastão de vidro.

$150 \mathrm{mg}$ de glicose/ $50 \mathrm{~g}$ de peso seco de solo foram adicionadas e homogeneizadas com bastão de vidro, a cada tempo de amostragem, ou seja: 0, 7, 14 e 28 dias.

Dentro de cada frasco foi colocado um frasco coletor universal de capacidade de $80 \mathrm{~mL}$ com um volume de $20 \mathrm{~mL}$ de $\mathrm{NaOH}(0,2 \mathrm{M})$, como armadilha para capturar o $\mathrm{CO}_{2}$ liberado. Os frascos foram fechados hermeticamente e incubados em BOD MA 415 à temperatura de $20 \pm 2{ }^{\circ} \mathrm{C}$, no escuro.

\subsubsection{Avaliação do dióxido de carbono $\left(\mathrm{CO}_{2}\right)$}

As amostragens foram feitas nos tempos: 0 dia (2; 4; 6; 8 e 10 horas); 7 dias (2; 4; 6; 8 e 10 horas); 14 dias (2; 4; 6; 8 e 10 horas) e 28 dias (2; 4; 6; 8 e 10 horas).

Para a avaliação da atividade microbiana utilizou-se a titulometria, uma das técnicas propostas pelo EPA (1996) e Carmo (2001). Em cada amostragem foram injetados $2 \mathrm{~mL}$ de solução saturada de $\mathrm{BaCl}_{2}$, assim que cada frasco de vidro era aberto, para precipitar o $\mathrm{CO}_{2}$ evoluído (Figura 4).

O frasco armadilha foi retirado e colocado outro com uma nova solução de $\mathrm{NaOH}(0,2 \mathrm{M})$ e novamente incubados nas condições supracitadas.

Duas gotas de fenolftaleína, como indicador, foram adicionadas aos frascos para titulação com $\mathrm{HCl}(0,1 \mathrm{M})$ até o desaparecimento da coloração rósea.

A quantidade de $\mathrm{CO}_{2}$ liberado foi calculada, utilizando a fórmula abaixo:

mg de $\mathrm{C}-\mathrm{CO}_{2} \mathrm{~kg}^{-1}$ de solo $=\frac{(\mathrm{L} \text { branco }-\mathrm{L} \text { amostra }) \text { x Eq-gCO } 2 \text { x M ác. x } 1000}{\text { Eq-g ác x Peso seco da amostra x } 2}$

Onde:

$\mathrm{L}$ branco $=$ Leitura do volume gasto na titulação do branco

$\mathrm{L}$ amostra = Leitura do volume gasto na titulação da amostra 
Eq-g $\mathrm{CO}_{2}=$ Equivalente-grama do $\mathrm{CO}_{2}=22(1 \mathrm{~mol}$ do ácido está para 0,5 mol de $\mathrm{CO}_{2}$ )

M ác. = Molaridade do $\mathrm{HCl}=0,1 \mathrm{M}$.

Eq-g ác = Equivalente-grama do ácido $=1$

1000 = fator de conversão de gramas para kilogramas

2 = fator de conversão do resultado para horas

Peso seco da amostra $=50 \mathrm{~g}$ de solo

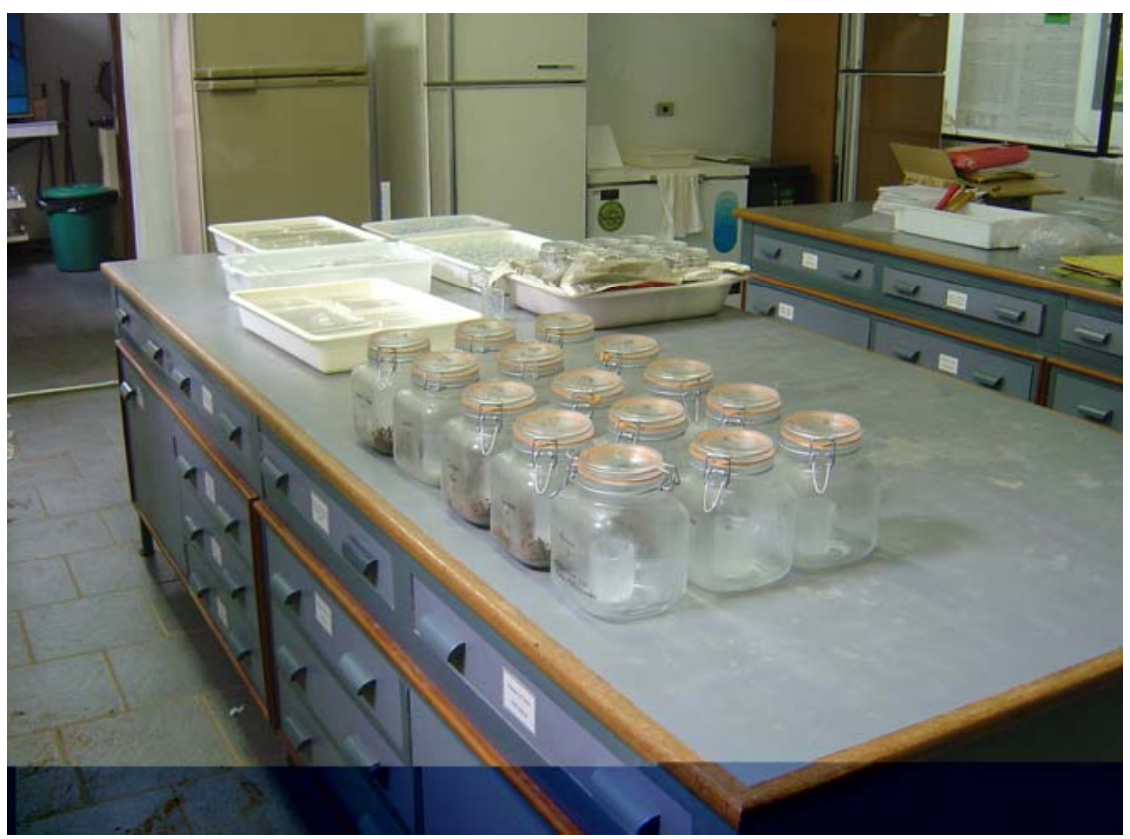

Figura 3 - Ensaio de transformação de carbono em frascos herméticos com armadilha de $\mathrm{NaOH}$ para captura de $\mathrm{CO}_{2}$ 


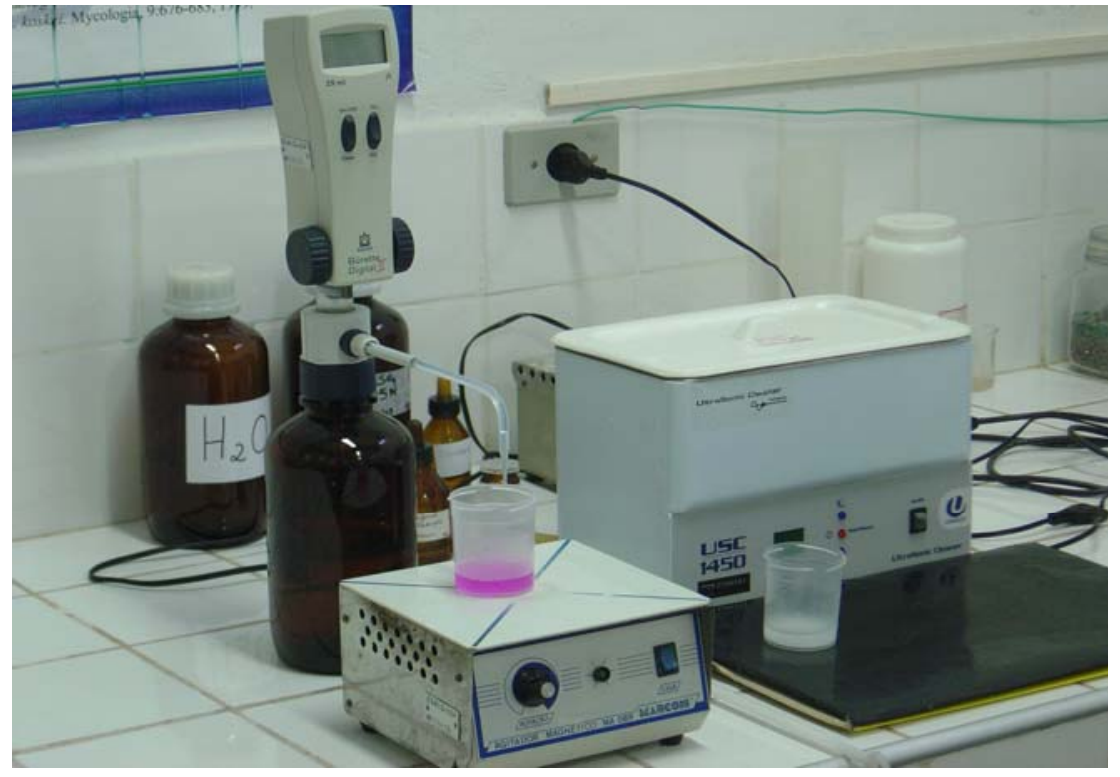

Figura 4 - Frasco com $10 \mathrm{~mL}$ de $\mathrm{NaOH}(0,2 \mathrm{M})$ e $\mathrm{BaCl}_{2}$ (saturado) para reação com o $\mathrm{CO}_{2}$ capturado na presença do indicador fenolftaleína e titulação com $\mathrm{HCl}(0,1 \mathrm{M})$

\subsection{Teste de transformação de nitrogênio}

\subsubsection{Materiais e Equipamentos}

- $\quad$ Cloreto de potássio

- $\quad$ Ácido sulfúrico

- $\quad$ Cloreto de sódio

- $\quad$ Sulfato de brucina

- $\quad$ Ácido sulfanílico

- $\quad$ Ácido clorídrico

- Balança analítica

- $\quad$ Balança Semi-Analítica

- $\quad$ Agitador de tubos

- $\quad$ Mesa agitadora 
- $\quad$ Freezer

- $\quad$ Espectrofotômetro Bio-Rad Microplate Reader Benchmark

- $\quad$ Estufa de secagem

- $\quad$ Liquidificador

- $\quad$ Papel de filtro

- $\quad$ Bastão de vidro

- $\quad$ Peneira

- $\quad$ Frascos plásticos - coletor universal

\subsubsection{Metodologia}

O teste foi conduzido baseado no procedimento descrito na norma da Organization for Economic Co-operation and Development - 216: Soil Microrganism: Nitrogen Transformation Test, (OECD, 2000b).

Um único solo, Argissolo Vermelho Amarelo Eutrófico abrúptico, foi utilizado de acordo com o descrito no item 3.2.2, cumprindo-se exigências do protocolo OECD (Tabela 6).

Previamente um teste para validação da metodologia foi preparado usando $10 \mathrm{~g}$ de solo (PV) para cada tratamento. As fortificações foram feitas com $\mathrm{KNO}_{3}$ (10 ppm) a: 0; 25; 50; 75 e $100 \%$. As diluições foram feitas com $\mathrm{KCl}(0,1 \mathrm{M})$, totalizando um volume de $10 \mathrm{~mL}$ para a fortificação de cada $10 \mathrm{~g}$ de solo. $\mathrm{O}$ solo fortificado foi agitado por uma hora a $150 \mathrm{rpm}$ filtrado em papel de filtro previamente tratado com $\mathrm{KCl}(0,1$ M). Uma alíquota de $1 \mathrm{~mL}$ desse filtrado foi submetido a extração pelo método de brucina (Brown et al., 1970) e determinação em espectrofotômetro em placas de Elisa, conforme descrito em 3.3.2.2.

\subsubsection{Preparo dos tratamentos}

Após a validação do teste de determinação de nitrato pelo método de brucina, foram preparados os seguintes tratamentos:

C - Controle;

C+S - Controle + substrato orgânico; 
C+O - Controle + Natur'l Oil (0,4 $\mu \mathrm{L}$ de Natur'l Oil/ 150g);

$\mathrm{C}+\mathrm{O}+\mathrm{S}$ - Controle + Natur'l Oil $(0,4 \mu \mathrm{L}$ de Natur'l Oil/ 150 g) + substrato orgânico;

DMA - 140,1 $\mu$ g do ingrediente ativo endosulfan/ $150 \mathrm{~g}$ de solo e

$\mathrm{DMA}+\mathrm{O}-140,1 \mu \mathrm{g}$ do ingrediente ativo endosulfan $+0,4 \mu \mathrm{L}$ de Natur'l Oil/ 150 g de solo.

A substância teste sem óleo foi solubilizada com $60 \mu \mathrm{L}$ de acetona p.a. O solvente foi evaporado à temperatura ambiente e o volume completado com água deionizada até um volume total de $1 \mathrm{~mL}$ para ambos os tratamentos, sendo que DMA+O recebeu o Natur'l Oil. As soluções foram colocadas em ultrassom por 3 minutos. A concentração de DMA, na presença e ausência do óleo apresentou como uma suspensão homogênea, apresentando uma forma mais leitosa com a adição do óleo. Foram aplicados $333 \mu \mathrm{L}$ de cada tratamento. Volumes iguais de água e água + Natur’l Oil foram colocados nos controles.

$150 \mathrm{~g}$ de solo passado em peneira de $2 \mathrm{~mm}$ de malha, foram colocados em frascos de vidro hermeticamente fechados de 2,0 L. O solo foi reativado com água obtida em Milli-Q e corrigido a 50\% da capacidade de campo. Os frascos foram mantidos em incubadora no escuro por um período de 7 dias a $20 \pm 2{ }^{\circ} \mathrm{C}$. Para cada tratamento foram preparadas três réplicas.

Como substrato orgânico, $5 \mathrm{~g}$ de alfafa foram adicionados em $1 \mathrm{~kg}$ de solo (0,75 g de alfafa moída / 150 g de solo) e homogeneizados com bastão de vidro.

O endosulfan e o Natur'l Oil foram aplicados de acordo com os tratamentos descritos anteriormente e homogeneizados com um bastão de vidro.

Os frascos foram incubados no escuro a $20 \pm 2{ }^{\circ} \mathrm{C}$. Para determinação do nitrato os frascos foram amostrados nos dias 0; 7; 14 e 28.

O reagente brucina foi preparado dissolvendo $1,0 \mathrm{~g}$ de sulfato de brucina e $0,1 \mathrm{~g}$ de ácido sulfanílico em $70 \mathrm{~mL}$ de água deionizada e a mistura aquecida à $\pm 70{ }^{\circ} \mathrm{C}$. Foram adicionados $3 \mathrm{~mL}$ de ácido clorídrico concentrado, a solução foi deixada esfriar e o volume completado em balão volumétrico de $100 \mathrm{~mL}$. 


\subsubsection{Avaliação do nitrato $\left(\mathrm{NO}_{3}{ }^{-}\right)$}

Na determinação do nitrato, $10 \mathrm{~g}$ de solo foram amostrados em cada réplica dos tratamentos e transferidos para um frasco plástico e adicionados $50 \mathrm{~mL}$ de uma solução de $\operatorname{KCl}(0,1 \mathrm{M})$ por réplica.

Os frascos plásticos com solo e $\mathrm{KCl}$ foram agitados por 1 hora a 150 rpm e após este período o conteúdo dos frascos filtrado em papel de filtro pré-lavado com $\mathrm{KCl}(0,1$ $\mathrm{M})$.

As amostras foram armazenadas em freezer para que toda a extração fosse feita de uma só vez no final do experimento. As amostras foram deixadas à temperatura ambiente para descongelamento. Coletou-se $1 \mathrm{~mL}$ do filtrado para análise de nitrato, utilizando três repetições por tratamento.

A cada $1 \mathrm{~mL}$ de amostra foram adicionados: $200 \mu \mathrm{L}$ de $\mathrm{NaCl}$ (30\%); $1 \mathrm{~mL}$ de ácido sulfúrico (14,5 M) e $50 \mu \mathrm{L}$ de reagente brucina para posterior agitação em agitador de tubos.

A mistura foi aquecida à $95{ }^{\circ} \mathrm{C}$ por 20 minutos até obtenção de coloração amarela. De cada tubo foram retirados $200 \mu \mathrm{L}$ e transferidos para poço da placa de Elisa. Este procedimento foi feito em triplicatas de cada tubo e a quantidade de nitrato foi determinada por colorimetria no espectrofotômetro Bio-Rad Microplate Reader Benchmark, a um comprimento de onda de $405 \mathrm{~nm}$.

Inicialmente foram avaliados os padrões de concentrações: 3; 4; 5; 6; 7; 8; 10 e 20 ppm na placa de Elisa, para estabelecimento da curva padrão em função da absorbância obtida e depois foram analisadas as amostras (Figuras 5 e 6). 


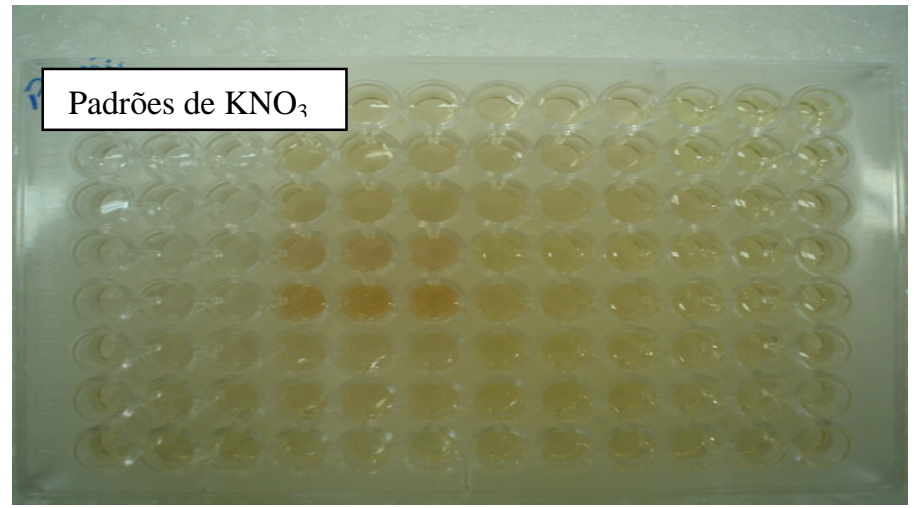

Figura 5 - Placa de Elisa com os padrões de $\mathrm{KNO}_{3}$ para estabelecimento da curva padrão em função da absorbância

Na Figura 6 podemos notar o gradiente de cor, identificando o aumento da concentração de nitrato nas amostras extraídas do solo, presentes no dia 0 até o $28^{\circ}$ dia.

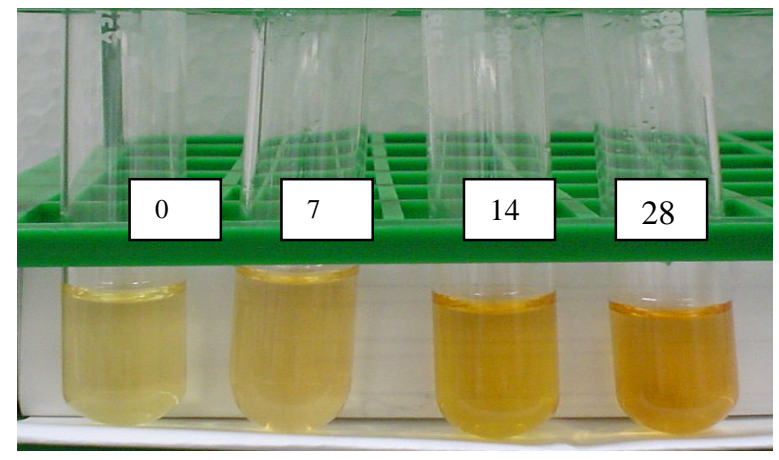

Figura 6 - Extração de nitrato em amostras de solo no tratamento $\mathrm{C}+\mathrm{S}$ pelo método de Brucina

\subsection{Teste de lixiviação}

\subsubsection{Materiais e Equipamentos}

- $\quad$ Permafluor

- $\quad$ Carbosorb

- $\quad$ Acetona 
- $\quad$ Colunas de vidro

- $\quad$ Espátula

- $\quad$ Régua

- $\quad$ Lã de vidro

- $\quad$ Funis de plástico e vidro

- $\quad$ Erlenmeyer

- $\quad$ Frasco de cintilação

- $\quad$ Prensa

- $\quad$ Oxidizer

- $\quad$ Analisador de cintilação líquida

- $\quad$ Bomba peristáltica

- $\quad$ Balança semi-analítica

\subsubsection{Metodologia}

O teste foi conduzido baseado na norma da Organization for Economic Cooperation and Development - Leaching in Soil Columns. (OECD, 1999).

Um único solo Argissolo Vermelho Amarelo Eutrófico (PV), foi utilizado cumprindo-se exigências dos protocolos OECD para transformação de carbono e nitrogênio.

Foram utilizadas seis colunas de vidro (colunas de lixiviação), com $5 \mathrm{~cm}$ de diâmetro e $40 \mathrm{~cm}$ de altura e com paredes de $2 \mathrm{~mm}$ de espessura. A extremidade inferior das colunas são afuniladas formando bico de aproximadamente $5 \mathrm{~cm}$ de comprimento.

Para o preenchimento das colunas de lixiviação com o solo, foi colocada lã de vidro na parte inferior e afunilada da coluna, seguida de uma camada de areia esterilizada. Com o auxílio de uma espátula, funil de haste longa e um martelo de borracha, para evitar a segregação de partículas e presença de bolha de ar, as colunas foram preenchidas com amostras de solo, onde foram feitas três repetições, de forma que foram adicionados $818,2 \mathrm{~g}$ de solo, passado em peneira $2 \mathrm{~mm}$ de malha, correspondendo a uma altura de $30 \mathrm{~cm}$. 
Depois de preenchidas, as colunas foram imersas em água destilada permitindo que a água subisse por capilaridade até o ápice da coluna. A Figura 7 mostra a disposição das colunas de vidro para o estudo da lixiviação.

\subsubsection{Preparo dos tratamentos}

Foram preparados dois tratamentos:

DMA - $137 \mu$ g do ingrediente ativo endosulfan/ coluna e

$\mathrm{DMA}+\mathrm{O}-137 \mu \mathrm{g}$ do ingrediente ativo endosulfan $+0,6 \mu \mathrm{L}$ de Natur' Oil/ coluna.

A solução estoque de endosulfan foi preparada pesando 3,86 mg em $10 \mathrm{~mL}$ de acetona. Dessa solução foram transferidos $2 \mathrm{~mL}$, sendo $1 \mathrm{~mL}$ para a solução A (com óleo) e outro $1 \mathrm{~mL}$ para a solução B (sem óleo). A acetona foi evaporada e a solução estoque A recebeu $27 \mu \mathrm{L}$ de ${ }^{14} \mathrm{C}$-endosulfan e $900 \mu \mathrm{L}$ de água deionizada e a solução estoque B recebeu $27 \mu \mathrm{L}$ de ${ }^{14} \mathrm{C}$-endosulfan mais $900 \mu \mathrm{L}$ de água deionizada com óleo. A atividade específica foi de 50,98 $\mu \mathrm{Ci} / \mathrm{mg}$ e a atividade total de $50 \mu \mathrm{Ci} / \mathrm{mL}$.

Os tratamentos DMA e DMA+O receberam $299 \mu \mathrm{L} /$ coluna, sendo solução estoque A e B, respectivamente. A dose de 137,41 $\mu \mathrm{g} /$ coluna corresponde a $700 \mathrm{~g}$ de endosulfan técnico/ ha e 0,6 $\mu \mathrm{L}$ de Natur’l Oil corresponde a 2L/ ha.

Para a checagem da concentração de trabalho através da radioatividade (spellcheck) das soluções estoques A e B, $1 \mu \mathrm{L}$ de cada solução estoque foi transferido para cada frasco de cintilação e efetuada a contagem. Este procedimento foi feito em triplicatas.

Após a aplicação das soluções A e B nas colunas, foi acondicionada uma camada de lã de vidro sobre a coluna de solo para impedir a formação do selo superficial devido ao impacto da gota de água ao solo e homogeneizar o molhamento. Este fluxo foi aferido para uma passagem de $0,14 \mathrm{~mL} \mathrm{~min}^{-1}$, simulando uma chuva de $200 \mathrm{~mm}$ por dia durante 60 horas. Para tal foi utilizada uma bomba peristáltica de vazão previamente calibrada. 


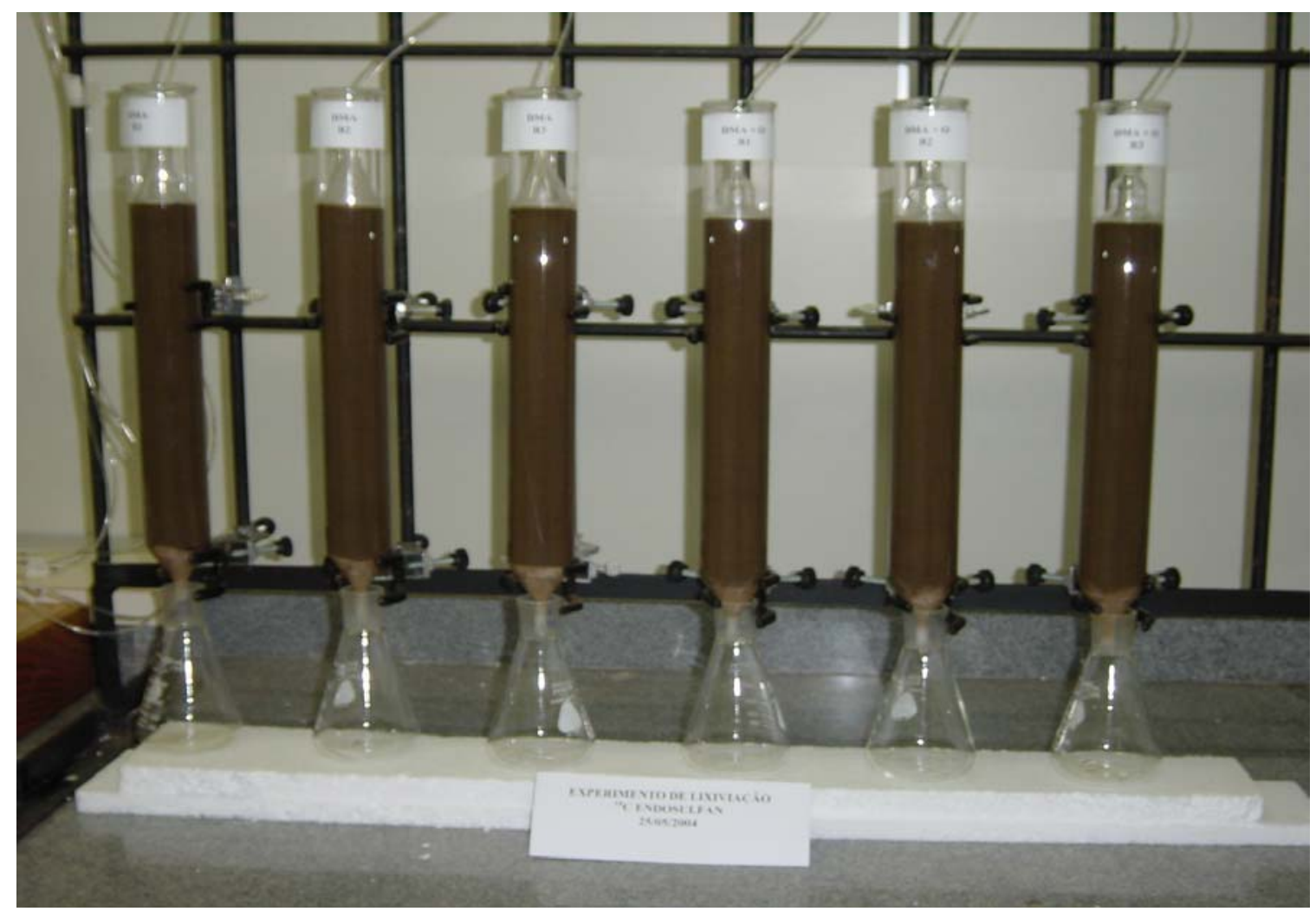

Figura 7 - Foto ilustrativa mostrando as colunas de vidro preenchidas com solo PV para o estudo de lixiviação de endosulfan na presença e ausência de Natur’l Oil

\subsubsection{Coleta do lixiviado}

O lixiviado foi coletado de 12 em 12 horas por um período de 48 horas, anotando-se os volumes. As determinações analíticas foram realizadas nos extratos em alíquotas de $5 \mathrm{~mL}$ do lixiviado, que foram transferidos em frasco de cintilação contendo $5 \mathrm{~mL}$ de instagel. Após a adição do lixiviado o frasco foi tampado e agitado para posterior leitura em cintilador. As coletas do lixiviado foram feitas em duplicatas por período de coleta (12 , 24, 36 e 48 horas) para cada tratamento.

\subsubsection{Seccionamento das colunas de solo}

Após 48 horas de fluxo constante de água e escoamento total das colunas, as colunas foram desmontadas com auxílio de ar comprimido submetido na porção 
afunilada das colunas, sendo o torrão de solo secionados em porções de $5 \mathrm{~cm}$ de comprimento $(0-5 ; 5-10 ; 10-15 ; 15-20 ; 20-25$ e 25-30 cm). Também a areia no final da coluna foi amostrada.

As porções de solo foram secas ao ar por 1 semana e foram homogeneizadas em gral com pistilo. De cada camada seccionada foram retiradas duas amostras de $300 \mathrm{mg}$ de solo cada para composição da pastilha, feita com papel absorvente dobrado e comprimido em uma prensa.

As pastilhas foram acondicionadas individualmente em frascos vazios de cintilação. As pastilhas foram oxidadas em Oxidizer H. Packard AO 307, por 3 minutos e o ${ }^{14} \mathrm{CO}_{2}$ liberado foi capturado em solução de carbosorb $(6 \mathrm{~mL})$ e permafluor $(12 \mathrm{~mL})$.

$\mathrm{O}$ equipamento foi aferido antes com padrões de ${ }^{14} \mathrm{C}$-glicose com concentração conhecida e realizadas as recuperações. O resultado mostrou uma recuperação de 94\%, portanto dentro dos limites estabelecidos como aceitáveis 90 - 110\%.

Os frascos de cintilação foram colocados em Analisador de Cintilação Líquida após um período aproximadamente de uma hora de repouso após agitação dos frascos, permitindo a estabilização das moléculas radiomarcadas com o permafluor e carbosorb. O tempo de leituras das amostras foi de 5 minutos.

\subsection{Teste de biodegradabilidade em solos}

\subsubsection{Materiais e Equipamentos}

- Diclorometano

- $\quad$ Hidróxido de potássio

- $\quad$ Hidróxido de sódio

- $\quad$ Ácido clorídrico

- Solução cintiladora

- $\quad$ Metanol

- $\quad$ Balança semi-analítica

- Balança analítica 
- $\quad$ Analisador de cintilação líquida

- Oxidador biológico

- $\quad$ Frascos biométricos

- $\quad$ Evaporador rotativo a vácuo

- $\quad$ Banho maria

- Bomba à vácuo

- $\quad$ Agitador magnético

- $\quad$ Extrator soxhlet

- $\quad$ Dispenser

- $\quad$ Balão volumétrico

- $\quad$ Erlenmeyer

- $\quad$ Kitassato

- $\quad$ Micropipeta

- $\quad$ Microseringa

- $\quad$ Funil de Büchner

- $\quad$ Frascos de cintilação de vidro

- $\quad$ Seringas descartáveis

- $\quad$ Pipeta de Pasteur

- $\quad$ Pipeta volumétrica

- Balão volumétrico

- $\quad$ Espátulas de aço

- $\quad$ Filtro Millipore $45 \mu \mathrm{m}$

- $\quad$ Microfiltro de lã de vidro

- $\quad$ Termômetro de máxima e mínima

\subsubsection{Metodologia}

O teste foi conduzido baseado no Procedimento para Teste de Biodegradabilidade em Solos, descrito na norma da OECD - 304A: Inherent Biodegradability in Soil (1999). 
O objetivo deste estudo foi determinar em laboratório, através de técnicas radiométricas, a degradação e a mineralização do endosulfan técnico radiomarcado na presença e ausência do Natur'l Oil, sob condições aeróbicas em solo Argissolo Vermelho Amarelo Eutrófico (PV), cumprindo-se exigências do protocolo OECD para testes de transformação de carbono e nitrogênio.

\subsubsection{Preparo dos tratamentos}

$50 \mathrm{~g}$ de solo seco e passado em peneira $2 \mathrm{~mm}$ de malha foram pesados e colocados em frascos biométricos Bartha \& Pramer (1965). Foram preparadas quatro réplicas por tratamento. A umidade do solo foi avaliada e mantida a $50 \%$ da capacidade de campo com água deionizada. O solo umedecido foi pré-incubado por 1 semana.

Após o período de pré-incubação foram preparados os seguintes tratamentos:

DMA - 46,7 $\mu \mathrm{g}$ de ingrediente ativo endosulfan/ $50 \mathrm{~g}$ de solo e

$\mathrm{DMA}+\mathrm{O}-46,7 \mu \mathrm{g}$ do ingrediente ativo endosulfan $+0,13 \mu \mathrm{L}$ do Natur'l Oil/ 50 g de solo).

A solução de ${ }^{14} \mathrm{C}$-endosulfan foi aferida e aplicou-se um volume suficiente para garantir 46,7 $\mu \mathrm{g}$ de ${ }^{14} \mathrm{C}$-endosulfan/ 1,5 g de areia pré-tratada. A acetona foi evaporada e o tratamento com adição do óleo (DMA+O), além do ${ }^{14} \mathrm{C}$-endosulfan recebeu $0,13 \mu \mathrm{L}$ de Natur'l Oil. A areia com os referidos tratamentos foi então incorporada ao solo.

Para calcular a dose com base no peso de solo, assumiu a densidade do solo igual a $1,5 \mathrm{~g} \mathrm{~cm}^{-3}$ e distribuição homogênea da substância-teste nos primeiros $5 \mathrm{~cm}$ do perfil do solo.

Para o spell-check das soluções $1 \mu \mathrm{L}$ da solução estoque foi transferido para cada frasco de cintilação e efetuada a contagem. Este procedimento foi feito em triplicatas.

Foram empregadas quatro repetições por solo para determinação da evolução de ${ }^{14} \mathrm{CO}_{2}$. O ${ }^{14} \mathrm{CO}_{2}$ desprendido foi aprisionado em solução de $\mathrm{KOH} \mathrm{0,1} \mathrm{M.}$

A umidade do solo foi mantida 50\% da capacidade de campo. Os frascos foram incubados em sala climatizada a $22 \pm 2{ }^{\circ} \mathrm{C}$. 


\subsubsection{Avaliação do dióxido de carbono $\left({ }^{14} \mathrm{CO}_{2}\right)$}

As soluções de $\mathrm{KOH}$ 0,1 M foram coletadas a 1, 2, 8, 16, 32 e 64 dias após a aplicação dos tratamentos propostos, para quantificação da evolução do ${ }^{14} \mathrm{CO}_{2}$.

Duas alíquotas de $1 \mathrm{~mL}$ da solução de $\mathrm{KOH}$ 0,1 $\mathrm{M}$ reagida com o ${ }^{14} \mathrm{CO}_{2}$ desprendido da substância-teste, contida no braço lateral de cada frasco biométrico, foram retiradas e adicionados $10 \mathrm{~mL}$ de solução cintiladora para contagem da radioatividade.

A radioatividade presente na solução de $\mathrm{KOH} 0,1 \mathrm{M}$ foi determinada por contagem em Espectrometria de Cintilação Líquida (ECL). Os resultados obtidos pela contagem da solução de $\mathrm{KOH}$ foram expressos em termos de porcentagem da radioatividade aplicada.

O restante da solução contida no braço lateral do frasco biométrico foi descartado em recipiente apropriado e, em seguida, $10 \mathrm{~mL}$ de uma solução recém preparada de $\mathrm{KOH} \mathrm{0,1} \mathrm{M} \mathrm{foram} \mathrm{adicionados.}$

\subsubsection{Amostragem e extração do solo}

As amostras de solo foram coletadas à 64 dias após a aplicação dos tratamentos, sendo a extração feita com diclorometano, solvente no qual a substância teste apresenta maior solubilidade (Roberts \& Hutson, 1999).

Após 64 dias o solo do frasco biométrico foi transferido para um Erlenmeyer, para realizar o processo de extração.

Em cada Erlenmeyer foram adicionados $150 \mathrm{~mL}$ de diclorometano e os mesmos foram submetidos a agitação por um período de uma hora em câmara escura à temperatura de $20 \pm 2{ }^{\circ} \mathrm{C}$, a fim de extrair a substância aplicada no solo (DMA e DMA+O). Após 1 hora o solo foi filtrado em microfiltro de fibra de vidro em funil de Büchner e kitassato acoplado a uma bomba de vácuo.

O solo retido no funil foi devolvido ao Erlenmeyer, e $150 \mathrm{~mL}$ de diclorometano, adicionado a esse solo obtendo-se um novo extrato, repetindo o processo de extração. Os 
dois extratos foram combinados em uma mesma proveta para se quantificar o volume do extraído.

Após as duas extrações, uma alíquota de $1 \mathrm{~mL}$ (em duplicata) do extrato final foi colocada em frascos de cintilação para determinação da radioatividade.

O restante do extrato foi adicionado a um balão de $200 \mathrm{~mL}$ e concentrado em evaporador rotativo, até aproximadamente $2 \mathrm{~mL}$. O concentrado contido no balão, foi transferido para um tubo de centrífuga graduado, com o auxílio de pipetas de Pasteur, lavando o balão contendo o extrato concentrado com pequenas porções de diclorometano para um volume máximo de $7 \mathrm{~mL}$.

Em seguida, o extrato foi filtrado em filtro Millipore de $45 \mu \mathrm{m}$ acoplado a uma seringa de $10 \mathrm{~mL}$ e transferido para frascos com capacidade de $10 \mathrm{~mL}$.

Uma alíquota de $100 \mu \mathrm{L}$ foi retirada para leitura em analisador de cintilação líquida para a determinação da atividade recuperada. Após a extração, o solo retido no funil foi submetido à determinação da fração não extraível, resíduo ligado do solo, conforme descrito em 3.5.2.5.

\subsubsection{Determinação da atividade microbiana no solo (radiorespirometria)}

Alíquotas de $2 \mathrm{~g}$ de solo de cada tratamento em três repetições foram coletadas e transferidas para frasco respirométrico no $64^{\circ}$ dia.

Uma pequena tira de papel filtro e $200 \mu \mathrm{L}$ de $\mathrm{NaOH}$ (2 M) foram adicionados no cachimbo de vidro suspenso na tampa de borracha. $500 \mu \mathrm{L}$ da solução de glicose ${ }^{14} \mathrm{C}$, na concentração de $2 \mu \mathrm{M}$ com atividade de $0,05 \mu \mathrm{Ci} / \mathrm{mL}$, foi preparada e adicionada ao solo.

O frasco respirométrico foi tampado e incubado durante 1 hora no escuro. Após esse período, $2 \mathrm{~mL}$ de $\mathrm{HCl}(1 \mathrm{M})$ foram colocados sobre o solo.

O conteúdo do cachimbo de vidro suspenso na tampa de borracha foi transferido para $10 \mathrm{~mL}$ de solução cintiladora e adicionado $2 \mathrm{~mL}$ de metanol. Foi deixado repousar por no mínimo 12 horas no escuro.

Após esse período os frascos externamente foram limpos com papel umedecido em álcool e colocados no cintilador líquido para leitura. 


\subsubsection{Combustão do solo para determinação do resíduo ligado.}

Após a extração, o solo deverá ser seco ao ar, destorroado e homogeneizado para então ser submetido à combustão em um oxidador biológico.

Para o processo de queima foram pesados $260 \mathrm{mg}$ de solo de cada tratamento DMA e DMA+O, em duplicatas e colocados em cones de combustão.

As amostras de solo foram oxidadas em Oxidizer H. Packard AO 307, por 3 minutos e o ${ }^{14} \mathrm{CO}_{2}$ liberado foi capturado em solução de carbosorb $(6 \mathrm{~mL})$ e permafluor (12 mL). O equipamento foi aferido antes com padrões de ${ }^{14} \mathrm{C}$-glicose com concentração conhecida e realizadas as recuperações. O resultado mostrou uma recuperação de 94\%, portanto dentro dos limites estabelecidos 90 - 110\%.

Os frascos de cintilação foram colocados em Analisador de Cintilação Líquida após um período de aproximadamente uma hora de repouso após agitação dos frascos, permitindo a estabilização das moléculas radiomarcadas com o permafluor e carbosorb. As amostras foram contadas por 5 minutos.

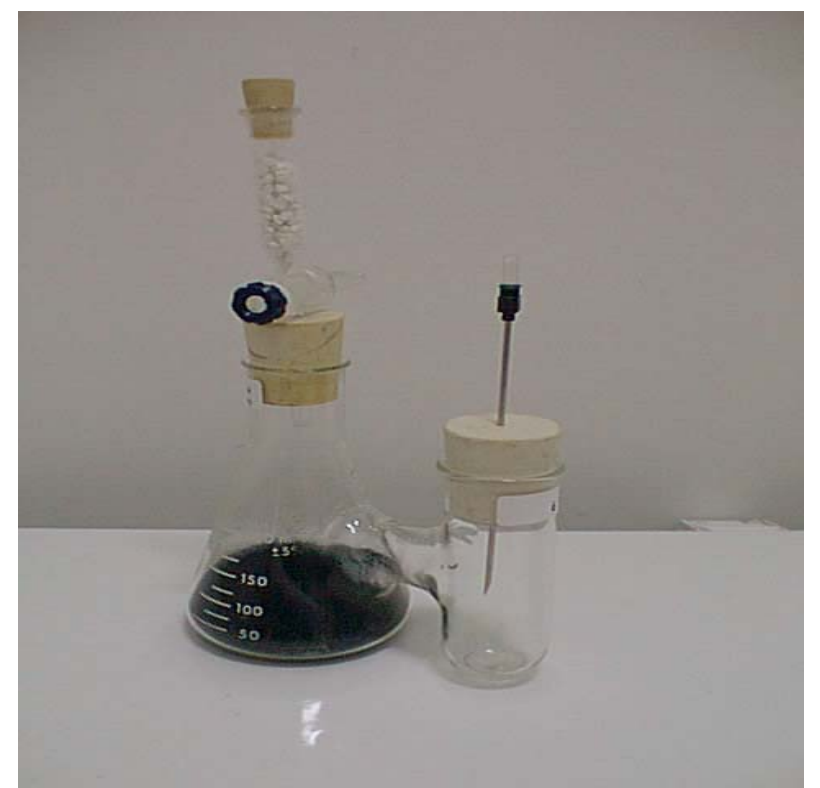

Figura 8 - Frasco de Bartha com solo e armadilha de $\mathrm{KOH} \mathrm{(0,1} \mathrm{M)} \mathrm{para} \mathrm{captura} \mathrm{do}$ ${ }^{14} \mathrm{CO}_{2}$ 


\section{RESULTADOS E DISCUSSÃO}

\subsection{Avaliação do efeito do endosulfan no crescimento fúngico de Aspergillus sp (linhagem Cad G1), em meio de cultura na presença e ausência de óleo vegetal.}

O cultivo de microrganismos em meio de nutritivo é o mais utilizado dos métodos de avaliação de densidade, embora sofra limitação séria, pois se estima que apenas cerca de $1 \%$ ou menos dos organismos do solo sejam cultiváveis, ou seja, apresentem crescimento em meio de cultura. No entanto, contagens em meio de cultura são ferramenta útil em estudos comparativos ou para microrganismos específicos (Moreira \& Siqueira, 2002).

Na Tabela 2 temos os valores médios do diâmetro das colônias de Aspergillus sp (linhagem Cad G1) observados nas avaliações de 2 e 6 dias.

O experimento possibilitou avaliar o efeito (a) do tipo de óleo (se de girassol ou de soja), (b) do tipo de processo ao qual o óleo foi submetido (se refinado ou degomado), (c) da concentração do óleo (se $0,1 \%$ ou 0,5\%) e também, (d) o efeito da composição do pesticida acrescentado ao meio de cultivo (se endosulfan com emulsificante, tal como nas preparações comerciais ou se apenas o emulsificante). Conforme pode ser visto na Tabela 3, na análise de variância, obteve-se os seguintes resultados: o efeito do tipo de óleo foi altamente significativo (prob. $>F=0,0003$ ) assim como os efeitos da concentração do óleo e da composição do pesticida (cada um deles, prob. $>\mathrm{F}=0,00001$ ), não sendo significativo o efeito do processo ao qual foi submetido o óleo (prob. $>\mathrm{F}=0,925$ ), ressaltando-se que foi altamente significativa a interação dos quatro fatores estudados (prob.>F=0,0007). O coeficiente de variação do experimento foi de $6,74 \%$. 
Tabela 2. Diâmetro médio das colônias fúngicas para todos os tratamentos propostos

\begin{tabular}{|c|c|c|}
\hline \multirow[t]{2}{*}{ Tratamentos: } & \multicolumn{2}{|c|}{ Diâmetro das colônias (cm) } \\
\hline & 2 dias & 6 dias \\
\hline $\mathrm{C}+\mathrm{I}$ & 1,75 & 4,46 \\
\hline $\mathrm{C}+\mathrm{OSRu}+\mathrm{I}$ & 1,89 & 4,80 \\
\hline $\mathrm{C}+\mathrm{OSDu}+\mathrm{I}$ & 1,54 & 3,98 \\
\hline $\mathrm{C}+\mathrm{OGRu}+\mathrm{I}$ & 1,67 & 4,34 \\
\hline $\mathrm{C}+\mathrm{OGDu}+\mathrm{I}$ & 1,84 & 3,92 \\
\hline $\mathrm{C}+\mathrm{EM}+\mathrm{I}$ & 1,76 & 3,60 \\
\hline $\mathrm{E}+\mathrm{I}$ & 0,19 & 0,74 \\
\hline $\mathrm{OSDu}+\mathrm{E}+\mathrm{I}$ & 1,10 & 3,91 \\
\hline $\mathrm{OSRu}+\mathrm{E}+\mathrm{I}$ & 1,01 & 3,99 \\
\hline $\mathrm{OSGu}+\mathrm{E}+\mathrm{I}$ & 0,89 & 3,21 \\
\hline $\mathrm{OSGu}+\mathrm{E}+\mathrm{I}$ & 0,86 & 3,25 \\
\hline $\mathrm{OSDc}+\mathrm{E}+\mathrm{I}$ & 0,78 & 2,56 \\
\hline $\mathrm{OSRc}+\mathrm{E}+\mathrm{I}$ & 0,53 & 1,99 \\
\hline $\mathrm{OGDc}+\mathrm{E}+\mathrm{I}$ & 0,79 & 2,70 \\
\hline $\mathrm{OGRc}+\mathrm{E}+\mathrm{I}$ & 0,61 & 2,10 \\
\hline OSDu+EM+I & 1,85 & 4,69 \\
\hline OSRu+EM+I & 1,01 & 3,60 \\
\hline $\mathrm{OGDu}+\mathrm{EM}+\mathrm{I}$ & 0,98 & 3,13 \\
\hline $\mathrm{OGDu}+\mathrm{EM}+\mathrm{I}$ & 1,26 & 3,78 \\
\hline OSDc+EM+I & 0,91 & 2,93 \\
\hline OSRc+EM+I & 1,20 & 3,78 \\
\hline $\mathrm{OGDc}+\mathrm{EM}+\mathrm{I}$ & 1,05 & 3,21 \\
\hline OGRc+EM+I & 1,08 & 3,81 \\
\hline
\end{tabular}


Constatou-se no conjunto dos tratamentos, que as médias de crescimento (diâmetro da colônia) foram significativamente superiores para o óleo de soja com relação ao óleo de girassol (Tabela 4-A), o que se confirmou no detalhamento das interações onde o óleo de soja se evidenciou como associado aos maiores valores de crescimento. Assim, dentro de óleo refinado, o de soja esteve associado a maior crescimento das colônias na concentração 0,1 \% com endosulfan e emulsificante, não se constando diferenças estatisticamente significativas nos demais tratamentos (Tabela 4B.1 a 4-B.4). Dentro de óleo degomado, o óleo de soja esteve associado ao maior crescimento das colônias na concentração de 0,1\%, tanto com endosulfan e emulsificante, como apenas com o emulsificante, mas a 0,5\% não houve diferenças estatisticamente significativas (Tabela 4-B.5 a 4-B.8).

Considerando o processamento do óleo, para o de girassol a 0,1\% + endosulfan e emulsificante, não houve efeito significativo sobre o crescimento das colônias. Mas, na concentração de 0,5\%, no óleo degomado houve maior crescimento. Quando se adicionou apenas o emulsificante, em ambas as concentrações houve maior crescimento no óleo refinado (Tabela 4-C.1 a 4-C.4). Para o óleo de soja a 0,1\%, com endosulfan e emulsificante, o crescimento foi maior quando o óleo foi refinado, mas a 0,5\% o crescimento foi maior em óleo degomado. Com a adição apenas de emulsificante, o crescimento das colônias foi maior em óleo degomado na concentração de 0,1 \% e maior em refinado, na concentração de 0,5\% (Tabela 4-C.5 a 4-C.8). Nas condições usuais de campo (Tabela 4-C.5), não se encontrando diferença significativa entre os processos, pode-se optar pelo mais vantajoso economicamente, ou seja o degomado. 
Tabela 3. Análise de variância de médias de diâmetro de colônia da linhagem Cad G1 de Aspergillus sp. cultivada em meio com dois tipos de óleo (girassol ou soja), submetidos a dois processamentos (refinamento ou degomagem), duas concentrações do óleo (0,1 e 0,5\%) e duas composições do pesticida adicionado ao meio (endosulfan com emulsificante ou apenas emulsificante)

\begin{tabular}{llcc}
\hline Fontes de Variação & GL & QM & Prob.> F \\
\hline Tipo de óleo & 1 & 0,9464 & 0,0003 \\
Processamento do óleo & 1 & 0,0004 & 0,9246 \\
Concentração do óleo & 1 & 7,8570 & 0,00001 \\
Composição do pesticida & 1 & 5,0960 & 0,00001 \\
Tipo * Processo & 1 & 0,3816 & 0,0087 \\
Tipo * Concentração & 1 & 2,1336 & 0,00001 \\
Tipo * Composição & 1 & 0,0024 & 0,8209 \\
Processo * Concentração & 1 & 0,0675 & 0,2485 \\
Processo * Composição & 1 & 0,7957 & 0,0006 \\
Concentração * Composição & 1 & 2,3320 & 0,00001 \\
Tipo * Processo * Concentração & 1 & 0,7252 & 0,0008 \\
Tipo * Processo * Composição & 1 & 0,4563 & 0,0048 \\
Tipo * Concentração * Composição & 1 & 0,00004 & 0,9760 \\
Processo * Concentração * Composição & 1 & 1,9200 & 0,00001 \\
Tipo*Processo*Concentração*Composição & & 0,7550 & 0,0007 \\
Resíduo & 32 & 0,0491 & \\
Total & 47 & & \\
Média Geral = 3,29 & CV(\%)=6,74 & \\
\hline
\end{tabular}


Tabela 4. Teste de Tukey para comparação de médias de diâmetro de colônia da linhagem Cad G1 de Aspergillus sp. cultivada em meios com diferentes composições (dados não transformados)

\begin{tabular}{|c|c|c|c|c|}
\hline & Norepetições & Médias & $5 \%$ & $1 \%$ \\
\hline \multicolumn{5}{|l|}{ A. Tipo de óleo } \\
\hline Soja & 24 & 3,43 & $\mathrm{a}$ & A \\
\hline Girassol & 24 & 3,15 & $\mathrm{~B}$ & $\mathrm{~B}$ \\
\hline D.M.S. $5 \%=0,130$ & D.M.S. $1 \%=$ & 0,175 & & \\
\hline \multicolumn{5}{|c|}{ B. Processamento do Óleo } \\
\hline \multicolumn{5}{|c|}{ Óleo Refinado } \\
\hline \multicolumn{5}{|c|}{ B.1. $0,1 \%+$ endosulfan e emulsificante } \\
\hline Soja & 3 & 3,99 & $\mathrm{a}$ & A \\
\hline Girassol & 3 & 3,25 & $\mathrm{~b}$ & $\mathrm{~B}$ \\
\hline \multicolumn{5}{|c|}{ B.2. $0,1 \%$ + emulsificante } \\
\hline Girassol & 3 & 3,78 & $\mathrm{a}$ & A \\
\hline Soja & 3 & 3,60 & a & A \\
\hline \multicolumn{5}{|c|}{ B.3. $0,5 \%+$ endosulfan e emulsificante } \\
\hline Girassol & 3 & 2,10 & $\mathrm{a}$ & A \\
\hline Soja & 3 & 1,99 & a & A \\
\hline \multicolumn{5}{|c|}{ B.4. 0,5\% + emulsificante } \\
\hline Girassol & 3 & 3,81 & $\mathrm{a}$ & A \\
\hline Soja & 3 & 3,78 & a & A \\
\hline \multicolumn{5}{|l|}{ Óleo Degomado } \\
\hline \multicolumn{5}{|c|}{ B.5. $0,1 \%+$ endosulfan e emulsificante } \\
\hline Soja & 3 & 3,91 & $\mathrm{a}$ & A \\
\hline Girassol & 3 & 3,21 & $\mathrm{~b}$ & B \\
\hline \multicolumn{5}{|c|}{ B.6. $0,1 \%$ + emulsificante } \\
\hline Soja & 3 & 4,69 & $\mathrm{a}$ & A \\
\hline Girassol & 3 & 3,13 & $\mathrm{~b}$ & B \\
\hline \multicolumn{5}{|c|}{ B.7. $0,5 \%$ + endosulfan e emulsificante } \\
\hline Girassol & 3 & 2,70 & $\mathrm{a}$ & A \\
\hline Soja & 3 & 2,56 & $\mathrm{a}$ & A \\
\hline \multicolumn{5}{|c|}{ B.8. $0,5 \%+$ emulsificante } \\
\hline Girassol & 3 & 3,21 & $\mathrm{a}$ & A \\
\hline Soja & 3 & 2,93 & $\mathrm{a}$ & A \\
\hline
\end{tabular}


Tabela 4. Teste de Tukey para comparação de médias de diâmetro de colônia da linhagem Cad G1 de Aspergillus sp. cultivada em meios com diferentes composições (dados não transformados)

\begin{tabular}{|c|c|c|c|c|}
\hline & Norepetições & Médias & $5 \%$ & $1 \%$ \\
\hline \multicolumn{5}{|c|}{ C. Adição de pesticida e(ou) adjuvante } \\
\hline \multicolumn{5}{|c|}{ Óleo de Girassol } \\
\hline \multicolumn{5}{|c|}{ C.1. $0,1 \%+$ endosulfan e emulsificante } \\
\hline Refinado & 3 & 3,25 & $\mathrm{a}$ & A \\
\hline Degomado & 3 & 3,21 & a & A \\
\hline \multicolumn{5}{|c|}{ C.2. $0,1 \%$ + emulsificante } \\
\hline Refinado & 3 & 3,78 & $\mathrm{a}$ & A \\
\hline Degomado & 3 & 3,13 & $\mathrm{~b}$ & $\mathrm{~B}$ \\
\hline \multicolumn{5}{|c|}{ C.3. $0,5 \%$ + endosulfan e emulsificante } \\
\hline Degomado & 3 & 2,70 & $\mathrm{a}$ & A \\
\hline Refinado & 3 & 2,10 & $\mathrm{~b}$ & $\mathrm{~B}$ \\
\hline \multicolumn{5}{|c|}{ C. $4.0,5 \%$ + emulsificante } \\
\hline Refinado & 3 & 3,81 & $\mathrm{a}$ & A \\
\hline Degomado & 3 & 3,21 & $\mathrm{~b}$ & $\mathrm{~B}$ \\
\hline \multicolumn{5}{|l|}{ Óleo de Soja } \\
\hline \multicolumn{5}{|c|}{ C.5. $0,1 \%+$ endosulfan e emulsificante } \\
\hline Refinado & 3 & 3,99 & a & A \\
\hline Degomado & 3 & 3,91 & $\mathrm{a}$ & A \\
\hline \multicolumn{5}{|c|}{ C.6. $0,1 \%$ + emulsificante } \\
\hline Degomado & 3 & 4,69 & $\mathrm{a}$ & A \\
\hline Refinado & 3 & 3,60 & $\mathrm{~b}$ & B \\
\hline \multicolumn{5}{|c|}{ C.7. $0,5 \%$ + endosulfan e emulsificante } \\
\hline Degomado & 3 & 2,56 & $\mathrm{a}$ & A \\
\hline Refinado & 3 & 1,99 & $\mathrm{~b}$ & $\mathrm{~B}$ \\
\hline \multicolumn{5}{|c|}{ C.8. $0,5 \%$ + emulsificante } \\
\hline Refinado & 3 & 3,78 & $\mathrm{a}$ & A \\
\hline Degomado & 3 & 2,93 & $\mathrm{~b}$ & $\mathrm{~B}$ \\
\hline D.M.S. $5 \%=0,369$ & D.M.S. $1 \%=$ & 0,496 & & \\
\hline
\end{tabular}


O aumento da concentração do óleo (de $0,1 \%$ para $0,5 \%$ ) em presença do adjuvante (emulsificante) só inibiu o crescimento das colônias para o óleo de soja degomado. Já o aumento da concentração do óleo, em presença do pesticida mais o adjuvante (endosulfan e emulsificante), reduziu significativamente o diâmetro das colônias em todos os tratamentos (óleo de soja ou girassol, refinados ou degomados) (Tabela 5 e Figura 9).

Tabela 5. Regressão Polinomial para comparação do efeito da concentração do óleo no meio de cultivo $(0,1 \%$ ou $0,5 \%)$ sobre as médias de diâmetro de colônia da linhagem Cad G1 de Aspergillus sp. cultivada em meios com diferentes composições - (dados não transformados)

\begin{tabular}{|c|c|c|c|}
\hline $\begin{array}{l}\text { Óleo -Processamento do óleo } \\
\text { Pesticida e(ou) adjuvante } \\
\text { adicionados ao meio de cultura }\end{array}$ & $\begin{array}{c}\text { Regressão } \\
\text { (Prob. > F) }\end{array}$ & Equação & $\mathrm{R}^{2}(\%)$ \\
\hline \multicolumn{4}{|l|}{ Girassol - Refinado } \\
\hline Endosulfan e emulsificante & 0,00001 & $y=3,54-2,87 x$ & 1,00 \\
\hline Emulsificante & 0,8667 - n.s. & - & - \\
\hline \multicolumn{4}{|l|}{ Girassol - Degomado } \\
\hline Endosulfan e emulsificante & 0,0085 & $y=3,34-1,27 x$ & 1,00 \\
\hline Emulsificante & 0,6904-n.s. & - & - \\
\hline \multicolumn{4}{|l|}{ Soja Refinado } \\
\hline Endosulfan e emulsificante & 0,00001 & $y=4,49-5,01 x$ & 1,00 \\
\hline Emulsificante & 0,3198 - n.s. & - & - \\
\hline \multicolumn{4}{|l|}{ Soja Degomado } \\
\hline Endosulfan e emulsificante & 0,00001 & $y=4,24-3,36 x$ & 1,00 \\
\hline Emulsificante & 0,00001 & $y=5,13-4,40 x$ & 1,00 \\
\hline
\end{tabular}




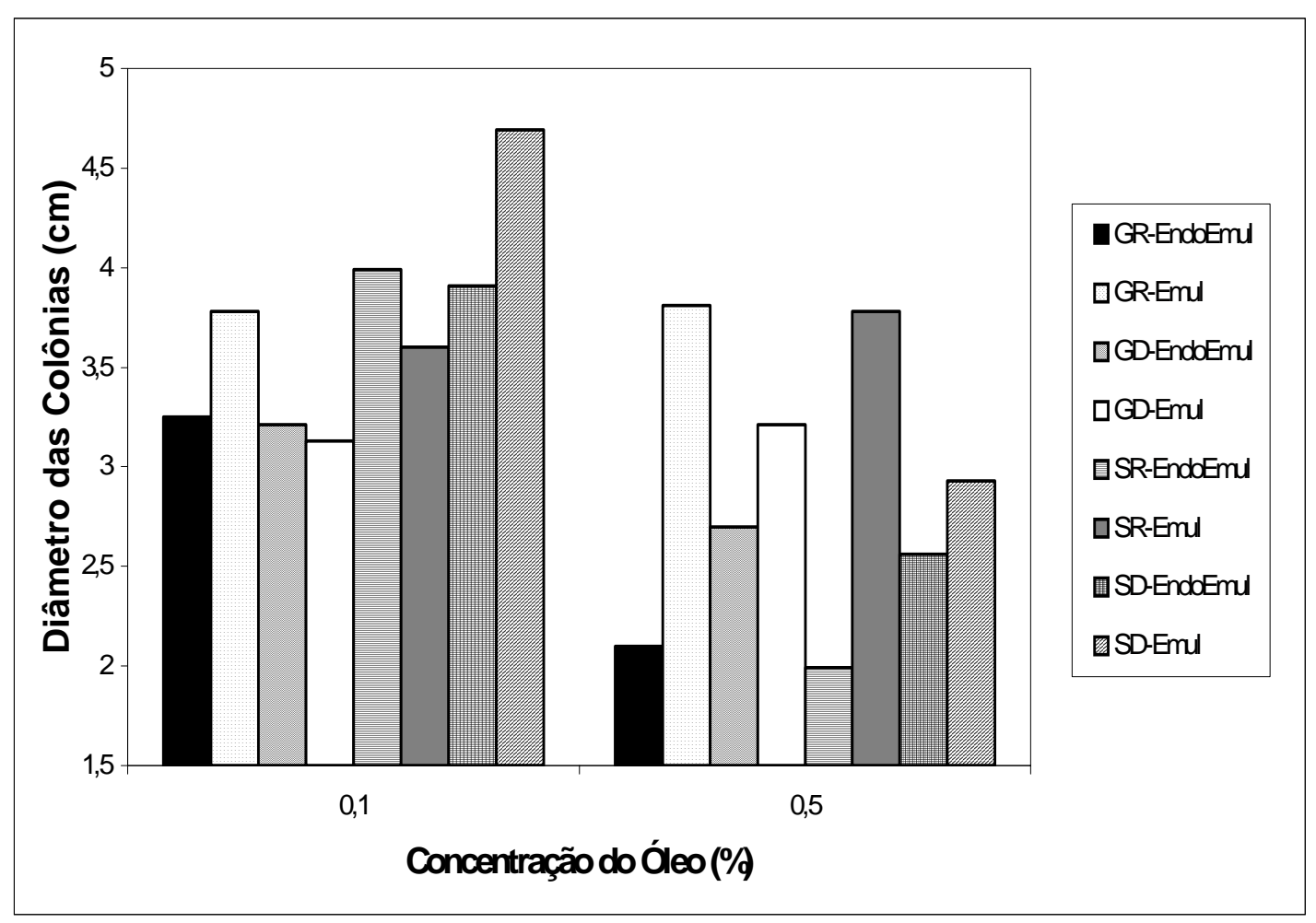

Figura 9 - Efeito da concentração, tipo e processamento do óleo e presença de endosulfan e(ou) emulsificante sobre o diâmetro das colônias de Aspergillus sp (linhagem Cad G1)

As placas submetidas à análise cromatográfica em cromatografo gasoso acoplado a detector de captura de elétrons para determinação de endosulfan sulfato apresentaram as seguintes médias: $\mathrm{C}+\mathrm{I}(0 \mathrm{ppm}) ; \mathrm{C}+\mathrm{EM}+\mathrm{I}(0 \mathrm{ppm}) ; \mathrm{E}+\mathrm{I}(0,03 \mathrm{ppm}) ; \mathrm{OSRu}+\mathrm{E}+\mathrm{I}$ (0,052 ppm); OSDu+E+I (0,078 ppm); OGRu+E+I (0,062 ppm) e OGDu+E+I (0,047 ppm).

Diante dos resultados apresentados, crescimento de colônia e resíduo de endosulfan sulfato, optou-se pelo óleo de soja degomado acrescido do emulsificante (OSDu), produto já existente comercialmente com o nome de Natur’l Oil. 
Na Figura 10 podem ser vistos os resultados do diâmetro médio das colônias de Aspergillus sp. (linhagem Cad G1) em controle, presença e ausência de endosulfan, Natur'l Oil e emulsificante, evidenciando um aumento de 81,07\% na presença do óleo $(\mathrm{OSDu}+\mathrm{E}+\mathrm{I})$, quando comparado à ausência do óleo $(\mathrm{E}+\mathrm{I})$.

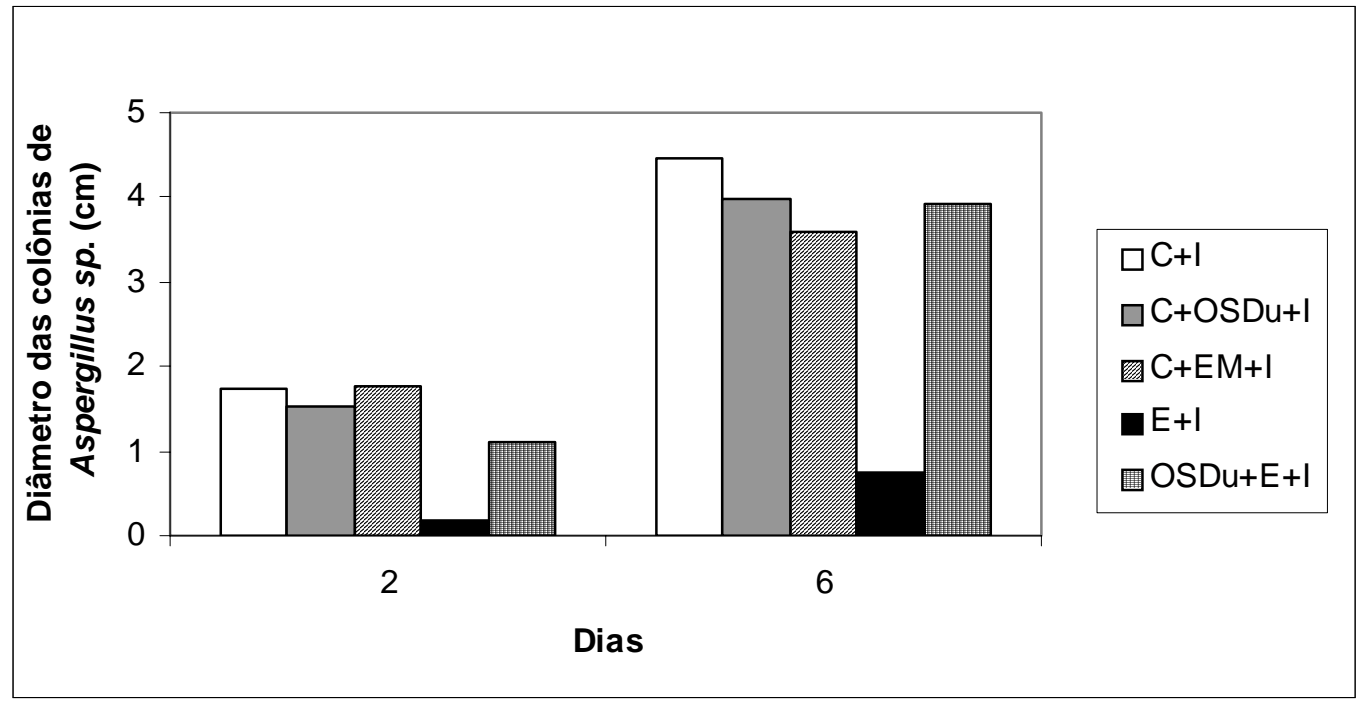

Figura 10 - Avaliação do diâmetro médio (cm) das colônias de Aspergillus sp. (linhagem Cad G1) no controle e na presença e ausência de endosulfan, Natur'l Oil e emulsificante

Os resultados apontam a redução da toxicidade do endosulfan para o fungo Aspergillus sp na presença do Natur’l Oil.

Com relação à degradação microbiana, Martens $^{1}$ (1976) citado por Miles \& Moy (1979), estudaram extensivamente a degradação do endosulfan em 28 espécies de fungos do solo e 50 espécies de bactérias in vitro por 10 dias. Metade das espécies de fungos formou o endosulfan sulfato e algumas poucas espécies formaram endosulfan diol, enquanto que as bactérias degradaram preferencialmente para o endosulfan diol, o mesmo ocorrendo com os actinomicetos. 
Segundo Roberts \& Hutson (1999) o endosulfan em meio de cultura foi degradado por culturas mistas de organismos de solos agriculturáveis, sob condições aeróbicas, sendo identificados o diol, o éter, a lactona e o éter hidroxi. Ambos os isômeros, $\alpha$-endosulfan e $\beta$-endosulfan, incubados com Aspergillus niger originaram o diol. Um microrganismo da família Pseudomonadae também originou o diol, como o maior metabólito.

Dentre as principais reações envolvidas nos processos de transformação está a oxidação de pesticida, uma das mais importantes e básicas dentre as reações metabólicas.

De acordo com Lawson (1995), os óleos naturais e gorduras de origem vegetal contem substâncias capazes de inibir a oxidação.

Com relação a atuação dos óleos sobre a inibição de processos oxidativos, estudos antigos efetuados com óleo de gergelim, mostraram a inibição no processo de epoxidação de ciclodienos (O’Brien, 1967).

Em estudo mais recente realizado por Lentza-Rizos \& Avramides (1991) com resíduos de inseticidas organofosforados em óleo de oliva, observou-se que o composto original fention foi o mais importante resíduo em amostras frescas, evidenciando a inibição da degradação por oxidação, enquanto que uma alta quantidade do metabólito fention sulfóxido foi verificado em amostras avaliadas somente após 104 dias.

De acordo com os resultados obtidos em estudos de avaliação dos níveis residuais de endosulfan em amostras de grãos, óleo e vagens de soja, verificou-se que o produto não sofreu degradação microbiana, devido à ausência do metabólito endosulfan sulfato, evidenciando que algum mecanismo estaria inibindo o processo de oxidação (Corrêa, 1999).

Em oposição a esses resultados pequena concentração de óleo pode resultar na prevenção do contato direto do pesticida com os microrganismos permitindo um contato gradual, contribuindo a uma fase lag maior, resultando em uma maior degradação in vitro do pesticida e utilização do mesmo, como fonte de nutrientes pelo fungo Aspergillus sp. (linhagem Cad G1), uma vez que o meio de cultura utilizado era o mínimo de cultivo proposto por Pontecorvo (1953). 
Os espalhantes adesivos largamente utilizados como adjuvantes na aplicação de pesticidas, quando misturados às moléculas criam uma barreira de proteção evitando o contato direto destes com os microrganismos, promovendo uma degradação gradativa.

De acordo com Bollag \& Liu (1990), os principais processos envolvidos no metabolismo microbiano de pesticidas são oxidação, redução, hidrólise e reações sintéticas. A oxidação de pesticidas que ocorre freqüentemente em microrganismos é uma das mais importantes e básicas reações metabólicas. As enzimas envolvidas em reações de oxidação de pesticidas estão relacionadas com vários grupos de enzimas oxidativas conhecidas, tais como as peroxidases e oxidases de múltiplas funções. Dentre as reações oxidativas podemos citar a epoxidação que é uma inserção de um átomo de oxigênio dentro de uma dupla ligação carbono-carbono, freqüentemente resulta na formação de produtos com grande toxicidade ambiental. Muitos microrganismos podem catalizar a reação de inseticidas ciclodienos clorados, aldrin, endosulfan, isodrin e heptaclor para seus epóxidos tóxicos derivados. Vários pesquisadores constataram que microrganismos tais como: Aspergillus niger, A. flavus, Penicillium chrysogenum, P. notatum, Rhizopus, Trichoderma e Fusarium podiam promover a epoxidação.

Algumas espécies de microrganismos podem sobreviver em condições extremas de salinidade, temperatura, pressão e pH. Além disso, os microrganismos, de modo geral, são bastante versáteis em adaptar-se às mudanças ambientais. Limitações físicas (e.g. água, aeração, porosidade, adesão) e químicas (e.g. disponibilidade de nutrientes e toxicidade de elementos como metais pesados aos microrganismos) podem ocorrer nos solos, mas muitas espécies são capazes de adaptar a essas condições (Moreira \& Siqueira, 2002).

O emprego de microrganismos conhecidos no tratamento de rejeitos potencialmente tóxicos, incluindo hidrocarbonetos de petróleo é uma prática habitual em alguns países desenvolvidos. Em estudo de biorremediação realizado em solos impactados por óleo cru, que corresponde à fração líquida do petróleo, cuja composição é de hidrocarbonetos alifáticos e aromáticos, compostos sulfidrilados, oxigenados e nitrogenados, e alguns metais dissolvidos em água, utilizando fungos filamentosos, 
mostraram que dentre os fungos avaliados o gênero Aspergillus apresentou a maior eficiência de degradação do petróleo (Macedo et al., 2002).

Podemos verificar com o presente estudo e o desenvolvido por Macedo et al. (2002) a eficiência do gênero Aspergillus para degradação de óleos, seja ele mineral ou vegetal.

Como método de avaliação in vitro, sugerimos aos órgãos geradores de procedimentos de estudos Organization for Economic Co-operation and Development OECD e Environment Protection Agency - EPA, a adoção do teste de degradação em meio mínimo de cultura inoculada com o(s) microrganismo(s) chave(s) envolvido(s) nos processos de transformação do pesticida em questão, através do diâmetro da colônia, como uma forma rápida e eficaz de avaliação.

\subsection{Teste de transformação de carbono}

Os resultados das análises químicas e granulométricas do solo Argissolo Vermelho Amarelo Eutrófico Abrúptico (PV) estão apresentados na Tabela 6.

Dados de coleta:

Local: Zona rural do município de Saltinho, Estado de São Paulo, Brasil

Coordenadas geográficas (GPS): $22^{\mathrm{O}} 56^{\prime} 11^{\prime}$ ' S e $47^{\circ} 43^{\prime} 24^{\prime \prime} \mathrm{W}$

Proprietário: Carlos Vettorazzi

Data de coleta: 23 de julho 2003

Profundidade de coleta: 0 - $20 \mathrm{~cm}$

Cobertura vegetal existente: pastagem

Não aplicação de pesticida nos últimos 12 meses

Não houve aplicação de fertilizantes orgânicos nos últimos 6 meses

Não houve aplicação de fertilizantes inorgânicos nos últimos 3 meses

A coleta foi realizada em período de seca prolongada. A amostra foi seca ao ar Responsável pela coleta, análise e informações: Dr. Pablo Vidal Torrado 
Tabela 6. Resultado das análises químicas e granulométricas do Solo Argissolo Vermelho Amarelo Eutrófico Abrúptico (PV)

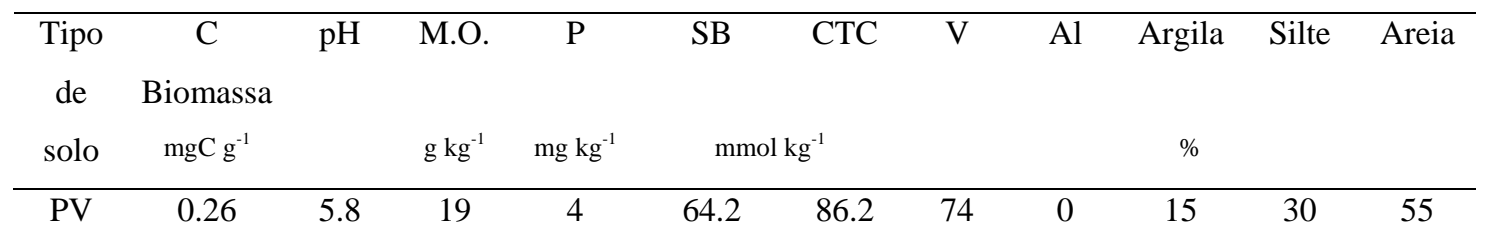

Raij et al, 1987 - Embrapa, 1999.

A metodologia de determinação de $\mathrm{CO}_{2}$ por titulometria foi utilizada neste estudo em razão da simplicidade e do custo das análises. Os resultados podem ser observados na Figura 11.

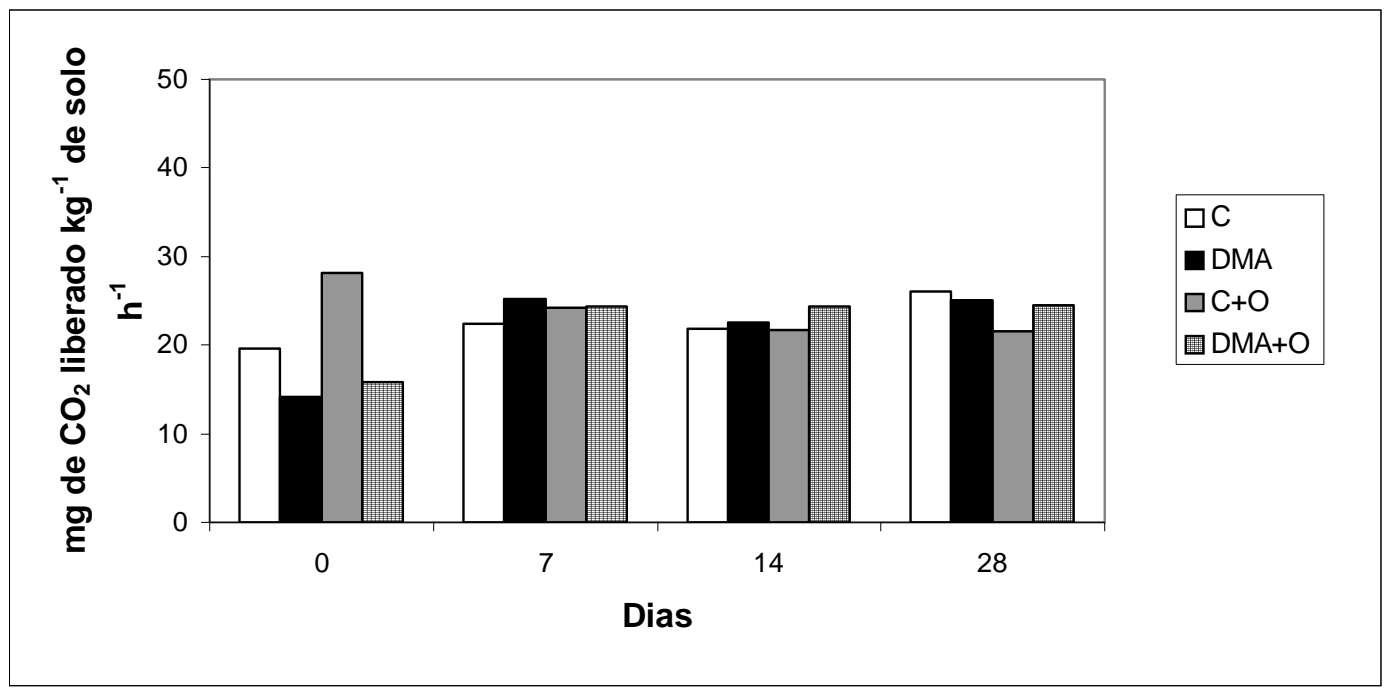

Figura 11- Comparação de $\mathrm{CO}_{2}$ liberado no teste de transformação de carbono com o endosulfan, na presença e ausência do Natur’l Oil

Quando um pesticida é aplicado ao solo, isso causará um ajuste na população microbiana presente. Quando os microrganismos capazes de degradar esses produtos já estiverem presentes no solo tratado ocorrerá um período denominado lag que pode variar de uma a duas semanas, no qual a concentração do pesticida não será alterada. Durante esse período, os microrganismos multiplicam-se rapidamente, pois se utilizam 
dos pesticidas como fonte de energia. Quando a população está suficientemente grande, o ataque às moléculas de pesticidas faz com que a concentração do produto se reduza e quando essa diminui a um nível abaixo daquele necessário para que o produto tenha atividade, diz-se que este foi inativado.

Segundo Moreira \& Siqueira (2002) quando se busca entender o impacto dos pesticidas sobre o solo e seus processos se faz necessária uma avaliação criteriosa e holística envolvendo todas as interações bióticas e abióticas. Apesar deste cenário complexo, evidências científicas disponíveis permitem afirmar que: “desde que os pesticidas sejam aplicados seguindo-se rigorosamente as recomendações técnicas, seus efeitos ecológicos e funcionais na comunidade microbiana do solo, são geralmente temporários”.

Respiração é um dos mais antigos parâmetros para quantificar a atividade microbiana. A decomposição dos pesticidas e de seus sub-produtos continua indefinidamente até que eles sejam reduzidos a dióxido de carbono, água e elementos básicos, como nitrogênio, enxofre, fósforo e outros.

De acordo com Frehse \& Anderson (1983), a taxa de metabolismo de pesticidas no solo é função de três variáveis consideradas chaves:

d) a disponibilidade dos produtos aos microrganismos ou aos sistemas enzimáticos;

e) a quantidade desses microrganismos ou dos sistemas enzimáticos;

f) o nível de atividade desses microrganismos ou desses sistemas enzimáticos.

A composição e distribuição dos átomos nas moléculas de pesticidas definem as propriedades físico-químicas e biológicas, portanto também a disponibilidade destes produtos à ação de microrganismos (Lavorenti, 1997).

Segundo Roberts \& Hutson (1999) o endosulfan em meio de cultura foi degradado por culturas mistas de organismos de solos agriculturáveis, sob condições aeróbicas, sendo identificados o diol, o éter, a lactona e o éter hidroxi. Ambos os isômeros, $\alpha$-endosulfan e $\beta$-endosulfan, incubados com Aspergillus niger originaram o diol. Um microrganismo da família Pseudomonadae também originou o diol, como o maior metabólito. 
No presente estudo verificou-se que não houve diferença estatística (Testes F e T) no processo de transformação de carbono do endosulfan na presença e ausência do óleo, mas notou-se um pequeno favorecimento da evolução do $\mathrm{CO}_{2}$ na presença de Natur'l Oil.

\subsection{Teste de transformação de Nitrogênio}

No ambiente, onde os pesticidas são aplicados há, geralmente, diferentes tipos de microrganismos, sendo que os principais encontrados no solo são as bactérias e os fungos. Esses organismos são capazes de transformar as moléculas, levando à sua inativação, assim como completa mineralização até $\mathrm{CO}_{2}, \mathrm{H}_{2} \mathrm{O}, \mathrm{NO}_{3}{ }^{-}$, etc.

A avaliação do nitrato significa a completa transformação do nitrogênio pelo processo de nitrificação que é a oxidação do íon amônio para nitrito e a oxidação do nitrito para nitrato, com participação de bactérias.

Na Figura 12 estão mostrados os resultados da formação de nitrato no teste de transformação de nitrogênio com o endosulfan, na presença e ausência de Natur'l Oil comparado aos controles, na presença e ausência do substrato orgânico e/ou Natur'l Oil.

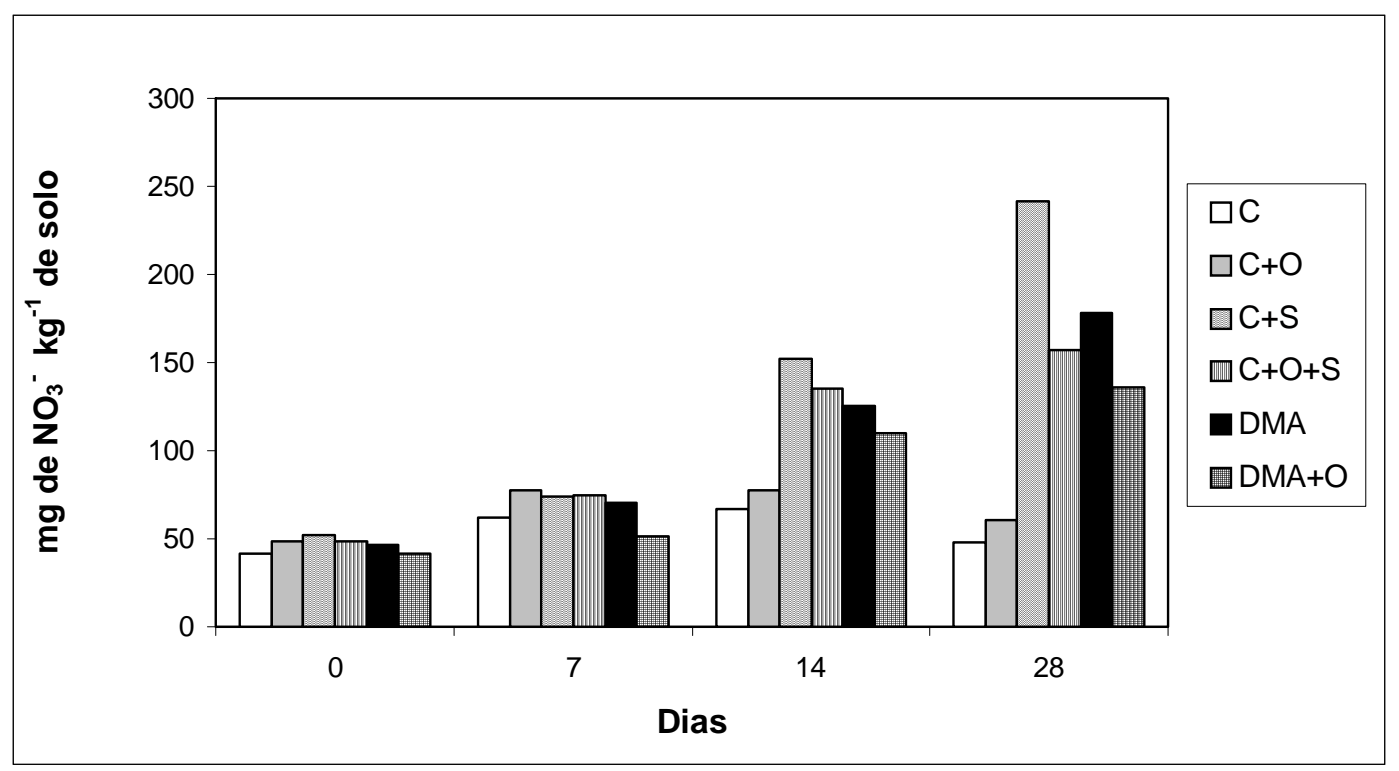

Figura 12 - Comparação de $\mathrm{NO}_{3}{ }^{-}$formado no teste de transformação de nitrogênio com o endosulfan na presença e ausência do Natur'l Oil 
De acordo com os resultados a adição de óleo parece ter promovido uma pequena redução na formação de nitrato comparando $\mathrm{C}+\mathrm{S}$ e $\mathrm{C}+\mathrm{O}+\mathrm{S}$, assim como DMA e DMA+O, porém não estatisticamente significativo, talvez pelo fato do óleo poder apresentar um efeito bactericida.

Métodos colorimétricos têm sido extensivamente usados para determinar formas inorgânicas de $\mathrm{N}$ em extratos de solo. Suas vantagens principais são rapidez e conveniência, particularmente quando análises são feitas em um grande número de amostras. (Mulvaney, 1996).

No presente estudo a quantificação por colorimetria em aparelho de alta sensibilidade, como é o caso do espectrofotômetro BIO-RAD Microplate Reader Benckmark, comprovou a possibilidade de se trabalhar em microescala, minimizando a geração de resíduos das análises laboratoriais e conseqüentemente reduzindo a contaminação ambiental.

\subsection{Teste de Lixiviação}

A técnica de avaliação da lixiviação de produtos químicos radiomarcados por colunas de vidro utilizando solo submetido a uma chuva simulada de $200 \mathrm{~mm}$, adotada no presente estudo propiciou uma boa aproximação das condições do perfil do solo no campo, concordando com Weber et al. (1994); OECD (1999) e Tornisielo (2003).

As Figuras 13 e 14 mostram a distribuição de ${ }^{14} \mathrm{C}$-endosulfan (\%) nas secções de solo $(0-30 \mathrm{~cm})$ e $(5-30 \mathrm{~cm})$, respectivamente, areia e lixiviado, na presença e ausência do Natur'l Oil.

O comportamento dos agrotóxicos no solo é de extrema complexidade por implicar em numerosas interações entre as fases sólidas, líquidas e gasosas. O processo de adsorção/dessorção dos agrotóxicos, pelos colóides orgânicos e inorgânicos do solo é de natureza físico-química e controla a concentração do produto na solução do solo, determinando a sua atividade biológica, mobilidade e volatilidade (Lavorenti, 1997). 


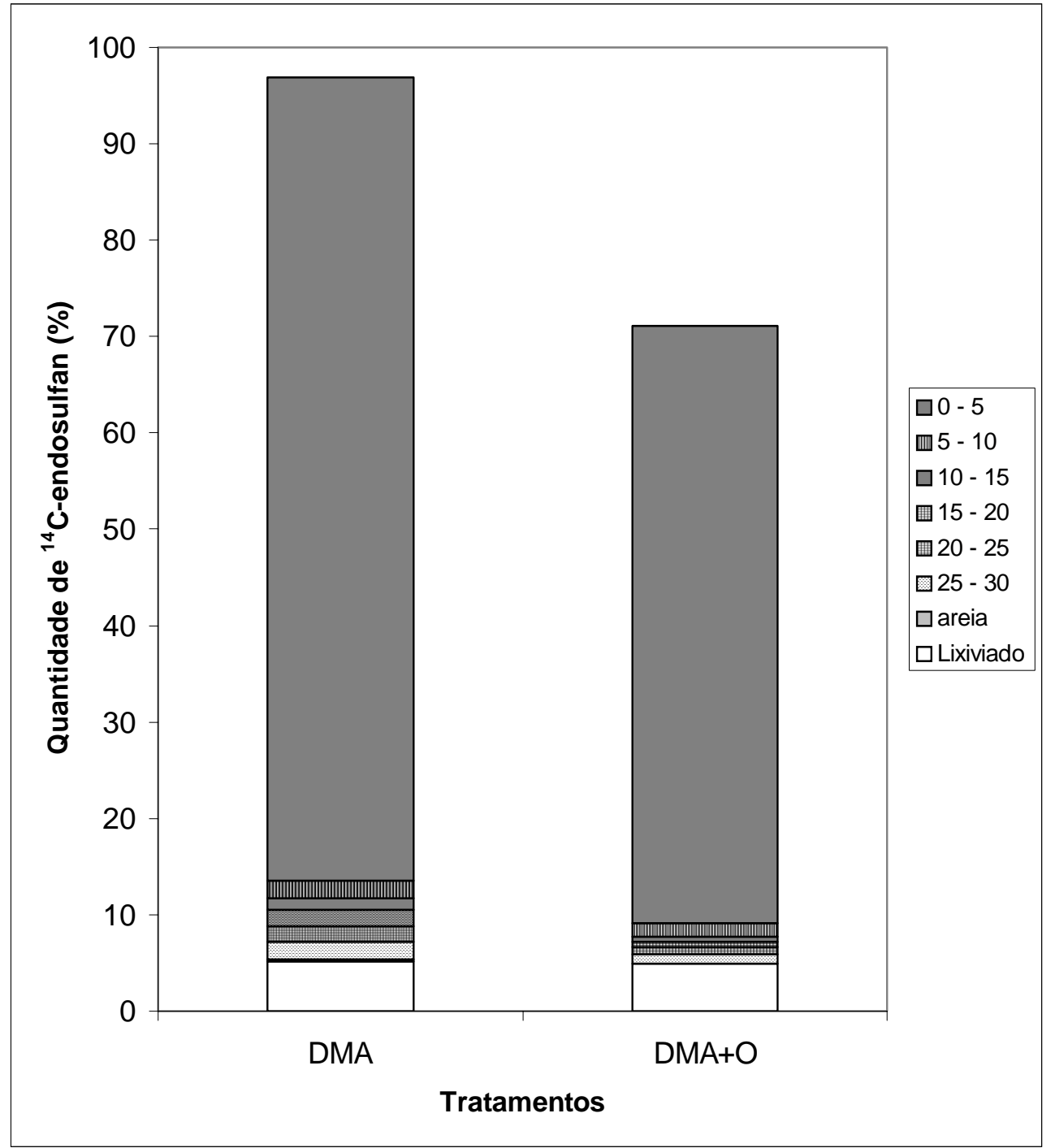

Figura 13 - Distribuição de ${ }^{14} \mathrm{C}$-endosulfan (\%) nas secções de solo $(0-30 \mathrm{~cm})$, areia e lixiviado, na presença e ausência do Natur'l Oil

Segundo Luchini et al., (1984) estudos sobre o comportamento de pesticidas em solos brasileiros revelaram diferenças nos seus movimentos, por apresentarem propriedades físico-químicas distintas. 
A baixa solubilidade do endosulfan e dos seus metabólitos é a razão para sua alta adsorção às partículas orgânicas do solo, e caracteriza sua baixa mobilidade (Lehr, 1992).

Quanto ao processo químico, Goebel et al. (1982) sugere dois mecanismos de degradação química: a hidrólise dando formação ao endosulfan diol e a oxidação originando o sulfato de endosulfan, que é o resíduo principal depois da aplicação do produto.

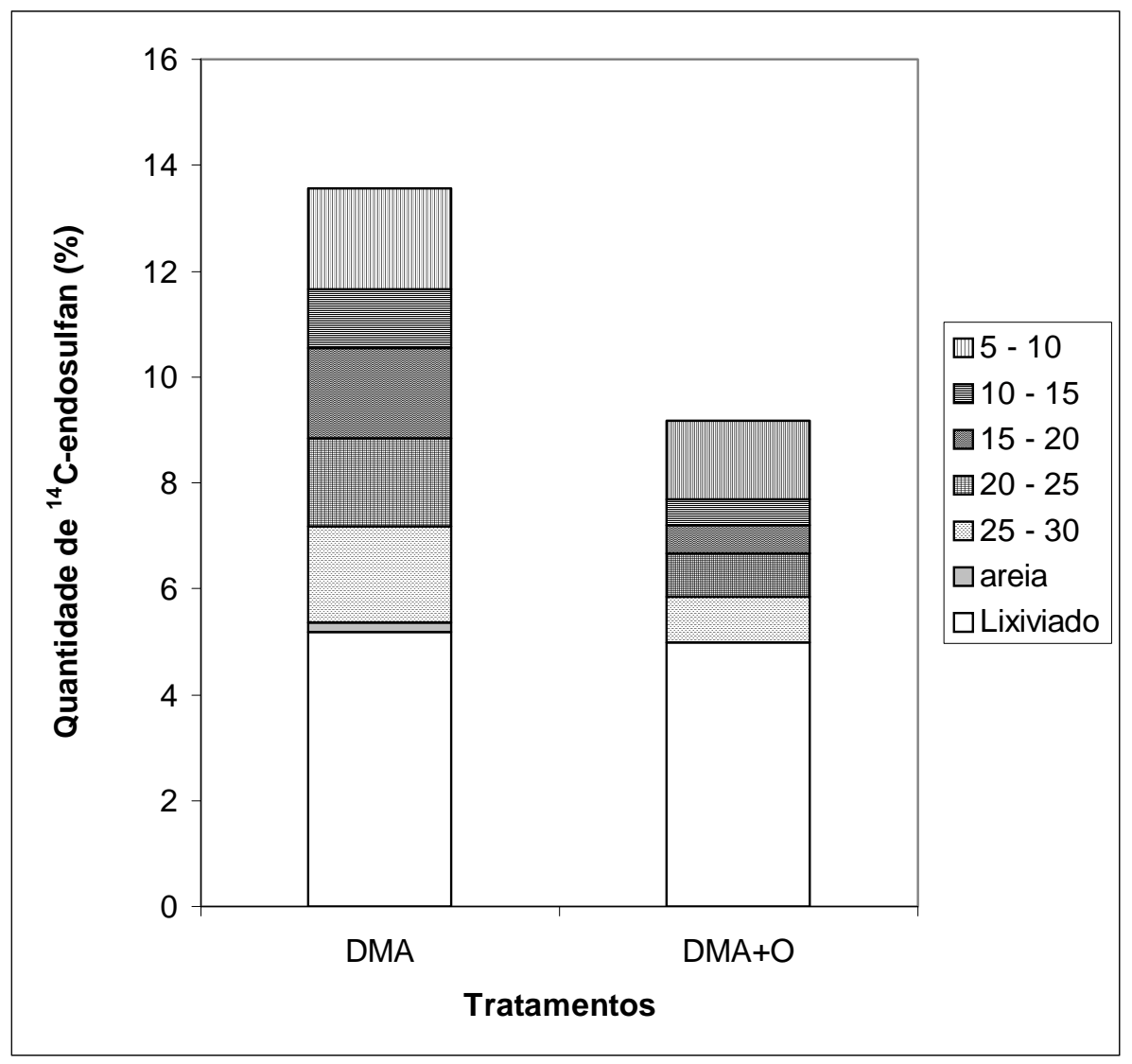

Figura 14 Distribuição de ${ }^{14}$ C-endosulfan (\%) nas secções de solo $(5-30 \mathrm{~cm})$, areia e lixiviado, na presença e ausência do Natur’l Oil

No presente estudo temos uma condição de solo a 100\% da capacidade de campo favorecendo que o endosulfan sofra hidrólise e dê a formação do endosulfan diol, 
concordando com os resultados de Roberts \& Hutson (1999) que verificaram que o endosulfan é rapidamente hidrolizado em água ao endosulfan diol, mas é moderadamente persistente em solo onde é convertido ao sulfato, que é altamente persistente. Outros metabolismos incluem o diol e muitos produtos gerados por oxidação do diol: éter, hidroxi-éter e a lactona. Nestes metabólitos, o resíduo clorado permanece inalterado, mas pode ser susceptível a declorinação por microrganismos.

O fato de trabalharmos com a saturação do solo por água faz com que haja competição da molécula da água por sítio de trocas catiônicas promovendo a biodisponibilidade do pesticida e conseqüentemente favorecendo a degradação microbiana.

De acordo com Janhel (1997) para muitos microrganismos, as melhores condições de desenvolvimento ocorrem em solos arenosos, em torna da capacidade de campo e em solos argilosos em torno da metade da capacidade de campo.

Estes dados colaboram com a condição de saturação do teste de lixiviação, evidenciando uma maior atividade microbiana.

Sob condições subtropicais, quando o endosulfan foi aplicado em solo arenoargiloso, a volatilização foi a principal rota de dissipação. A dissipação foi ocasionada pela conversão ao endosulfan sulfato e o diol, sendo a persistência do sulfato maior que 238 dias, enquanto que o diol foi dissipado quase que totalmente dentro de 28 dias (Kathpal et al., 1997).

Segundo Tornisielo \& Silva (1993a) em estudos conduzidos em colunas de lixiviação com ${ }^{14}$ C-endosulfan em solos: Latosssolo Roxo, Latossolo Vermelho Amarelo e Areia Quartzosa, a quantidade lixiviada pode ser considerada relativamente baixa, pois do total do inseticida aplicado permaneceram nos solos 97,8; 86,2 e 93,3\%, respectivamente. Destes percentuais, permaneceram na faixa de 0 a 2 cm: 73,4; 82,3 e 78,7 \%. Estes dados confirmam resultados encontrados em estudos conduzidos por Tornizielo \& Silva (1993b), que demonstraram médio potencial de adsorção em solos Areia Quartzosa e alto no solo Latossolo Vermelho Amarelo.

Os resultados do presente estudo mostram os seguintes percentuais de endosulfan: 91,68 e 66,04 no solo e para o lixiviado 5,18 e 4,98 nos tratamentos DMA e 
DMA+O, respectivamente. O percentual de endosulfan no solo, na ausência de óleo (DMA), confirma os resultados anteriormente encontrados por Tornisielo \& Silva (1993a) e Tornisielo \& Silva (1993b).

Os valores de lixiviado não diferiram entre si estatisticamente (Testes F e T), mas no solo obteve-se uma redução de $27,97 \%$ entre os tratamentos, evidenciando que a presença do óleo (DMA+O) promove uma menor adsorção do endosulfan e maior dissipação.

Foy (1992) estudou a lixiviação dos herbicidas: dicamba (altamente móvel), atrazina (intermediário) e clorprofan ou trifluralina (relativamente imóveis) em dois tipos de solos: orgânico (80\% de matéria orgânica) e outro com textura arenosa utilizando colunas e placas de TLC. Os surfactantes, em altas concentrações notoriamente aumentam a mobilidade dos herbicidas, no entanto o autor verificou que os surfactantes aniônicos (Sulfato de lauril sódio), não-iônicos (Hyamina 1622) e catônicos (Tween-80) testados causaram efeitos variáveis no movimento dos herbicidas, dependendo da dose e tipo de solo.

\subsection{Teste de biodegradabilidade em solos}

$\mathrm{O}$ órgão ambiental brasileiro baseia-se na taxa de liberação de ${ }^{14} \mathrm{CO}_{2}$ do produto num período de incubação de 28 dias para avaliar a persistência, categorizando os xenobióticos em não persistente (acima de 25\%) e de persistência reduzida (10 - 25\%), média $(1-10 \%)$ e alta (0 - 1\% de liberação de ${ }^{14} \mathrm{CO}_{2}$ ) (IBAMA, 1990).

Os resultados do teste de biodegradabilidade em solos estão na Figura 15.

Segundo os resultados encontrados no presente estudo a taxa de liberação de ${ }^{14} \mathrm{CO}_{2}$ do endosulfan foram 15,27\% (DMA) e 14,13\% (DMA+O), mostrando uma persistência reduzida para ambos os tratamentos.

De acordo com Roberts \& Hutson (1999) os isômeros $\alpha$-endosulfan e $\beta$ endosulfan são degradados no solo com valores de $\mathrm{DT}_{50}$ de 30 a 70 dias, respectivamente. O principal metabólito é usualmente o sulfato cíclico que é degradado mais lentamente que o original. Em estudos de campo, o $\mathrm{DT}_{50}$ para o endosulfan total ( $\alpha$-endosulfan e $\beta$-endosulfan e endosulfan sulfato) variaram de 5 a 8 meses. 


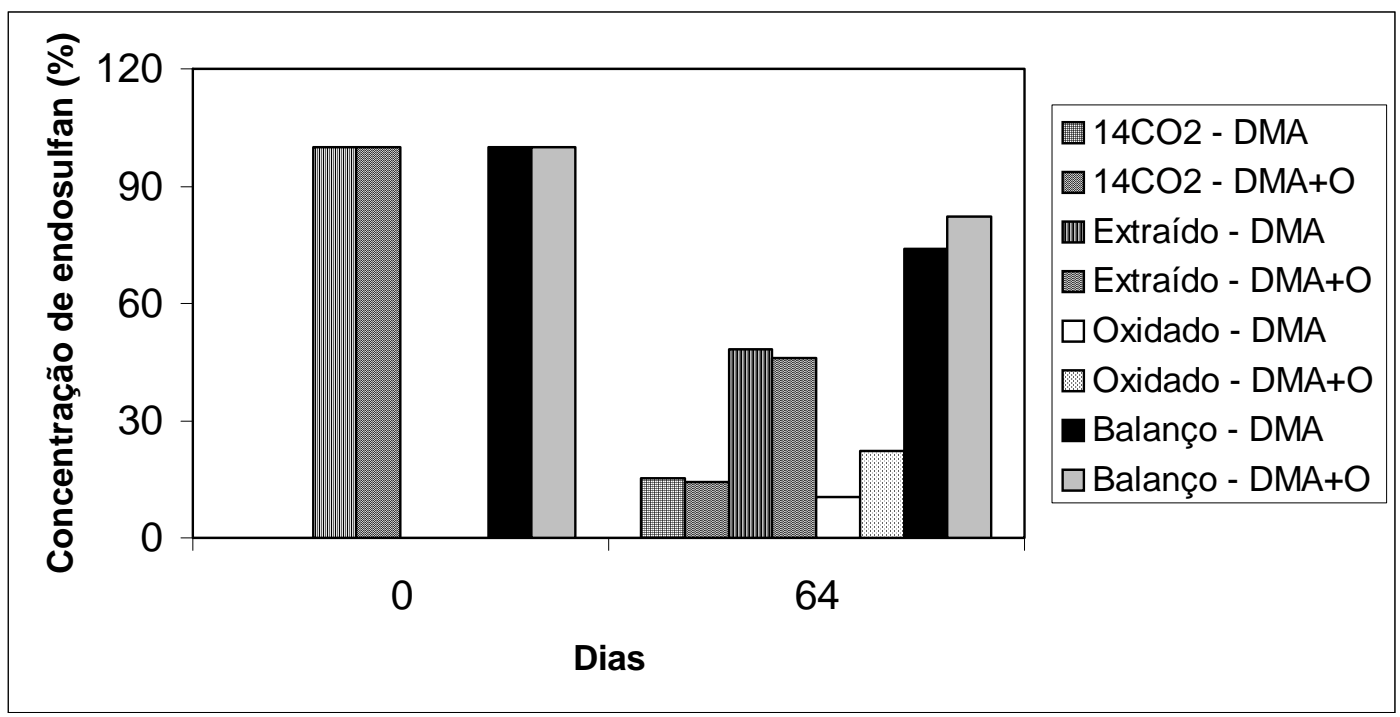

Figura 15 - Concentração percentual de ${ }^{14} \mathrm{C}$ - endosulfan no balanço de massas, evolução de ${ }^{14} \mathrm{CO}_{2}$ e endosulfan extraído e oxidado para os tratamentos DMA e DMA+O

O período de semi-decomposição ou meia-vida biológica do endosulfan varia entre 30-100 dias e estes valores são extremamente favoráveis em comparação com os valores de meia-vida para os demais organoclorados (DDT, Heptacloro, Endrin, Toxafeno, Aldrin, Dieldrin, Clordano e BHC) que variam de 365 a 4380 dias. (Khan, 1980).

Salientamos que o solo é um sistema dinâmico e complexo e que o comportamento de pesticidas no ambiente depende das características físico-químicas destes produtos, bem como as do próprio ambiente. E que o ambiente possui uma grande capacidade tampão recuperando o equilíbrio perdido, mostrando que os efeitos destes pesticidas à comunidade microbiana do solo, são geralmente temporários.

Mas para um planejamento efetivo e seguro do uso do solo é imperativo reconhecer o uso racional de pesticida, o recurso hídrico subterrâneo e a preservação da biodiversidade. A perda da biodiversidade da microbiota do solo pode levar à seleção de algumas espécies de microrganismos que consigam efetuar a degradação de produtos. 


\section{CONCLUSÕES}

Tendo em vista que a presença do Natur'l Oil não interfere nos processos de transformação de carbono e nitrogênio e no teste de biodegradabilide do endosulfan em solos e que no processo de lixiviação a presença do óleo trouxe incrementos positivos, desfavorecendo a percolação do pesticida, a adição de óleos como espalhante adesivo deve ser considerada na aplicação de pesticidas para redução de lixiviação e por evitar o contato direito dos pesticidas com os microrganismos de solo, proporcionando uma maior fase lag e a preservação da biodiversidade.

Como método de avaliação in vitro, a adoção do teste de degradação em meio mínimo de cultura inoculada com o(s) microrganismo(s) chave(s) envolvido(s) nos processos de transformação do pesticida em questão, através do diâmetro da colônia, pode ser uma ferramenta importante, rápida e eficaz para procedimentos de estudos de comportamento de xenobióticos. 


\section{REFERÊNCIAS BIBLIOGRÁFICAS}

AGÊNCIA NACIONAL DE VIGILÂNCIA SANITÁRIA - ANVISA. Toxicologia. http://www.anvisa.gov.br (15 maio 2003).

ANDREI E. Compêndio de defensivos agrícolas. Guia Prático de Produtos Fitossanitários para uso Agrícola, 5. ed. São Paulo Editora Andrei, 1995.

ANDREI E. Compêndio de defensivos agrícolas. Guia Prático de Produtos Fitossanitários para uso Agrícola, 6. ed. São Paulo Editora Andrei, 1999.

ASSOCIAÇÃO BRASILEIRA DAS INDÚSTRIAS DE ÓLEOS VEGETAIS ABIOVE. http://www.abiove.com.br (15 dez. 2004).

ASSOCIAÇÃO BRASILEIRA DA INDÚSTRIA DO CAFÉ - ABIC. Café, novos desafios e oportunidades. http://www.abic.com.br (16 fev. 2005)

BAPTISTA, G.C. Módulo 7 - Toxicologia, meio ambiente e legislação específica. In: CURSO DE PROTEÇÃO DE PLANTAS. Brasília: ABEAS, 1995, 71p.

BARTHA, R.; PRAMER, D. Features of a flask and method for measuring the persistence and biological effects of pesticides in soil. Soil Science. v. 100, n.1, p.68-70, 1965.

BOLLAG, D.C.; LIU,S.Y. Biological transformation processes of pesticide. In: CHENG, H.H. (Ed.). Pesticide in the soil environment: process, impacts and modeling. Madison: Soil Science Society of America, p. 169-211, 1990.

BONETTI, L.P. Distribuição da soja no mundo. In MYASAHKA S.; MEDINA J.C. (Ed) A soja no Brasil, Campinas: ITAL, 1981, cap,1, p.1-6, 1981.

BROOKS, G. T. Chorinated insecticides: biological and environment aspects. Boca Raton: CRC Press, 1976. 197p. 
BROWN, E.; SKOUGSTAD, M.W.; FISHMAN, M.J. Methods for collection and analysis of water samples for dissolved minerals and gases. Washington, United States Geological Survey, 1970. 160p.

CARMO, J. B. Impacto da aplicação de biossólidos nas atividades microbianas do solo. Piracicaba, 2001. 105p. Dissertação (Mestrado) - Escola Superior de Agricultura “Luiz de Queiroz”, Universidade de São Paulo.

CHOW, P.N.P.; GRANT, C.A. Research and development of agro-adjuvants: A bibliographic Survey. In: FOY, C.L. (Ed.) Adjuvants for chemicals. Boca Raton: CRC Press, cap. 1, p. 3-15, 1992.

CORRÊA, C.M.D. Avaliação dos níveis residuais de endosulfan em soja (Glycine max - L. Merrill) e solo (Latossolo Roxo) cultivado nos sistemas convencional e manejo integrado de pragas (MIP). Piracicaba, 1999. Dissertação (mestrado). Centro de Energia Nuclear na Agricultura.

COSTA, S.L. A soja na produção de alimentos. In: SEMINÁRIO NACIONAL DE PESQUISA DE SOJA, Londrina, 1978. Anais. Londrina: EMBRAPA-CNPSo, 1979. v.2, p.235-243.

CU, R.M.; PHIPPS, P.M.; STIPES, R.J. Adjuvants effects of Soyoil $9379{ }^{\circledR}$ on fungicides for control of early leafspot and sclerotinia blight in peanuts. In: FOY, C.L. (Ed.). Adjuvants for chemicals. Boca Raton: CRC Press, cap. 65, p. 657-666, 1992.

EMPRESA BRASILEIRA DE PESQUISA AGROPECUÁRIA - EMBRAPA Sistema brasileiro de classificação de solos. Brasília: Embrapa Produção de informação, EMBRAPA/CNPS, 1999. 412 p.

ENVIRONMENTAL PROTECTION AGENCY. Ecological Effects Test Guidelines

Soil Microbial Community Toxicity Test. OPPTS 850.5100. EPA 712-C-96-161, Public draft, 1996.

ESTADO DE SÃO PAULO. Setor de açúcar e álcool vive euforia com U\$ 6 bilhões de investimentos. http://www.fenasucro.com.br (09 ago. 2004).

ESTADO DE SÃO PAULO. Algodão, o ouro branco brasileiro, pode seguir o caminho da soja. http://www.brasilnews.com.br (09 maio 2004). 
FARRELL, P.M.; ROBERTS, R.J. Vitamin E. In: SHILS, M.E.; OLSON, J.O. (Ed.). Modern nutrition in health and disease. 8.ed. Baltimore: Williams \& Wilkins, 1994. v.1, cap.18, p.326-341.

FOSTER, S.S.D. Poluição das águas subterrâneas: um documento executivo da situação da América Latina e Caribe com relação ao abastecimento de água potável. Instituto geológico, São Paulo, 1993, 55p.

FOY, C. L. Influence of certain surfactants on the mobility of selected herbicides in soil. In: FOY, C.L. (Ed.). Adjuvants for chemicals. Boca Raton: CRC Press, cap. 33, p. 350-365, 1992.

FRANCO, L. Nunca se exportou tanto café. http://www.brasilnews.com.br (23 jul. 2003).

FREHSE, H.; ANDERSON, J.P.E Pesticides residues in soil - problems between concept and concern. In: GREENHALG, R.; DRESCHER,N (Ed.) Pesticide chemistry, human welfare and the environment. Oxford: Pergamon Press, 1983. v. 4, p. 23-32.

GOEBEL, H. GORBACH, S.; KNAUF, W.; RIMPAU, R.H.; HÜTTENBACH, H. Properties, effects, residues and analytics of the inseticide endosulfan. New York: Springer-Verlag, 1982. 174p. (Residue Reviews, 83).

HANCE, R.J. FÜHR, F. Methods to study fate and behaviour of pesticides in the soil In: FÜHR, F.; HANCE,R.J. Lysimeters studies of the fate of pesticides in the soil. Farnham: BCPC, 1992. Monograph n.53.

HUTTENBACH, H. Thiodan: fields of application and survey of technical literature Residue Reviews, v. 83, p.112-137, 1982.

INTERNATIONAL ATOMIC ENERGY AGENCY. Laboratory training manual on the use of nuclear techniques in pesticides research. Viena, 1983. 291p. (Technical Reports Series, 225).

INSTITUTO BRASILEIRO DO MEIO AMBIENTE E RECURSOS NATURAIS RENOVÁVEIS - IBAMA. Manual de Testes para Avaliação da Ecotoxicidade de Agentes Químicos, 1990. 
JAHNEL, M. C. Método de plaqueamento por gotas e outros parâmetros microbiológicos na avaliação da degradação de lodo ativado de curtume em solos. Piracicaba, 1997. p. 79. Tese (Doutorado) Escola Superior de Agricultura "Luiz de Queiroz”, Universidade de São Paulo.

KATHPAL, T.S.; SINGH, A.; DHANKHAR, J.S.; SINGH, G. Pesticide Science, 50, p. 21-27, 1997.

KAWAZAKI, L.I.; MIYASAWA, M.; PAVAN, M. A.; FRANCHINI, J. C. Determinação condutivimétrica de carbonato residual do calcário aplicado no solo por análise em fluxo. Instituto Agronômico do Paraná - IAPAR. Nota técnica, Química Nova 23 (4) p. 560-562, 2000.

KHAN, S.U. Pesticide in the soil environment. New York:Academic Press, 1980. 240p.

JARDIM, W.F.; PASQUINI, C. GUIMARÃES, J.R.; FARIA, L.C. Short-term toxicity test using Escherichia coli: Monitoring $\mathrm{CO}_{2}$ production by flowing injections analysis. Water Resource, v. 24, n.3, p.351-354, 1990.

LAMBAIS, M.R. Poluição orgânica e seu controle. In: Microbiologia do Solo, In: CARDOSO, E.J.B.N.; TSAI, S.M.; NEVES, M. C. P.(Ed.), Campinas, Sociedade Brasileira de Ciência do Solo, 1992. cap. 7, p. 91-104.

LAVORENTI, A. Comportamento de Agrotóxicos no Ambiente. Material didático do Departamento de Química. Escola Superior de Agricultura “Luiz de Queiroz” ESALQ/USP, Piracicaba, São Paulo, 1997.

LAWSON, H. Food Oils and Fats: Technology, Utilization and Nutritional. United Stated of América: Chapman \& Hall, 1995, cap. 3, p. 15-27.

LEHR, W. Statement concerning soil metabolism and mobility of endosulfan. (Hoe 002671) Frankfurt: HOECHST, 1992 p.1-8 (Report, PSR-WLO2/92).

LEHR,W. Statement concerning the chemical classification of endosulfan. Frankfurt: HOECHST, 1993, p.1-3 ( Report, PSR-93/034).

LENTZA-RIZOS, C.; AVRAMIDES, E.J. Organophosphorus inseticide residues in Virgin Greek Olive Oil, 1988-1990. Pesticide Science, v.32, n. 2, p.161-171, 1991. 
LUCHINI, L.C.; HIRATA,R.; RUEEGG, E.F. Sorção e mobilidade de pesticidas associados a propriedades físico-químicas de solos de Cerrado do Estado de São Paulo. Pesquisa Agropecuária Brasileira, v. 19, n.2, p.157-162, 1984.

MACEDO, R.C; BERBET, V.H.C.; LEMOS, J.L.S.; TRINDADE, P.V.O.; RIZZO, A.C.L. Biorremediação de solos impactados por óleo cru utilizando fungos filamentosos. In: X Jornada de Iniciação Científica. Anais. Rio de Janeiro: Centro de Tecnologia Mineral - CETEM, 2002.

MILES, J.R.W.; MOY, P. Degradation of endosulfan and its metabolities by a mixed of culture of soil microorganism. Bulletin of Environmental Contamination and Toxicology, v.23, p.13-19, 1979.

MOREIRA, F.M.S.; SIQUEIRA, J.O. Microbiologia e bioquímica do solo. Lavras: Editora Ufla, 2002, 626 p.

MULVANEY, R.L. Nitrogen - Inorganic Forms. BARTELS, J.M. Methods of Soil Analysis. Part 3 - Chemical Methods. SSSA Book Series Madison 1996, cap. 38, p.1123-1184. Soil Science Society of America and American Society of Agronomy. MUNNECKE, D.M.; JOHNSON, L.M.; TALBOT H.W.; BARIK, S. Microbial metabolism and enzymology of selected pesticides. In: CHAKRABARTY, A.M. (ed.) Biodegradation and detoxification of environmental pollutants. Boca Raton CRC Press, 1982, p.1-32.

NAKANO, O. Contribuição ao estudo do comportamento de alguns organo-sintéticos quando adicionado de espalhantes adesivos. Piracicaba, 1969. p. 106. Tese (Doutorado) Escola Superior de Agricultura “Luiz de Queiroz”, Universidade de São Paulo.

O’BRIEN, R.D. Insecticides action and metabolism. New York: Academic Express, 1967. cap.7, p.133-147: Cyclodienes.

ODUM, E. P. Ecologia. Trad. de TRIBE, C.J. Rio de Janeiro: Editora Guanabara, Rio de Janeiro, 1988. p. 111-139.

ORGANIZATION FOR ECONOMIC CO-OPERATION AND DEVELOPMENT Inherent Biodegradability in Soil. 1999. 11p. (OECD Guideline for Testing of Chemicals - 304A). 
ORGANIZATION FOR ECONOMIC CO-OPERATION AND DEVELOPMENT. Leaching in Soil Columns. 1999. 13p. (OECD Guideline for Testing of Chemicals). ORGANIZATION FOR ECONOMIC CO-OPERATION AND DEVELOPMENT. Guideline for testing of Chemicals. Soil microorganism: Carbon transformation Test. OECD - 217, adopted in $21^{\text {st }}$ January 2000a.

ORGANIZATION FOR ECONOMIC CO-OPERATION AND DEVELOPMENT. Guideline for testing of Chemicals. Soil microorganism: Nitrogen transformation Test. OECD - 216, adopted in $21^{\text {st }}$ January 2000b.

PONTECORVO, G.; ROPER, J.A.; HEMMONS, L.M.; MacDONALD, K.D.; BUFTON,A.W.J. The genetics of Aspergillus nidulans. Advances in Genetics, v.5, p.141-238, 1953.

RAIJ, B.V; QUAGGIO, J.A.; CANTARELLA, H.; FERREIRA, M.E; LOPES, A.S.; BATAGLIA, O.C. Análise química do solo para fins de fertilidade. Campinas: Fundação Cargill, 1987. 170p.

RODELLA, A.A.; SABOYA, L.V. Calibration for conductimetric determination of carbon dioxide. Soil Biology and Biochemistry. n.31, p. 2059-2060, 1999.

ROBERTS, T.; HUTSON, D.H. Metabolic Pathways of Agrochemicals. Inseticides and Fungicides, Cambridge: The Royal Society of Chemistry, 1999, v. 2.

SALA, O.E.; CHAPIN III, F.S.; ARMESTO, J.J.; BERLOW,E.; BLOOMFIELD,J.D; HUBER-SAWALD, E.; HUENNEKE, L.F.; JACKSON, R.B.; KINZIG,A.; LEEMANS,R.; LODGE, D.M.; MOONEY, H.A.; OESTERHELD, M.; POFF, N.L.; SYKES , M.T.; WALKER, B.H; WALKER, M.; WALL, D.H. Global Biodiversity Scenarios for the year 2100. Science, v. 287, p1770-1774, 2000.

SELBORNE, L. A ética do uso da água doce: um levantamento. Brasília: UNESCO, 2002, 80p.

TORNISIELO, V.L. Estudos do comportamento de pesticidas no solo, através do uso de colunas de lixiviação e lisímetros. Piracicaba, 2003, 105p.Tese (Livre docência). Centro de Energia Nuclear na Agricultura.

TORNISIELO, V.L; SILVA, P.M. Avaliação da mobilidade do inseticida endosulfan. Piracicaba: CENA, 1993a. 18p. (Relatório Técnico). 
TORNISIELO, V.L; SILVA, P.M. Avaliação da adsorção /desorção do inseticida endosulfan. Piracicaba: CENA, 1993b. 18p. (Relatório Técnico).

VINTEN, A.J.A.; SMITH K.A. Nitrogen Cycling in Agricultural Soils In: BURT, T.P.; HEATHWAITE, A.L.; TRUDGILL, S.T. (Ed.) Nitrate process, patterns and management. England: John Wiley \& Sons Ltd, 1993, cap. 3, p.39 - 97.

WEBER, J.B. Properties and behaviour of pesticides in soil IN HONEYCUTT, R.C.; SCHABACKER, D.J. (Ed). Mechanism of pesticide movement into groundwater. Boca Raton:CRC Press, 1994. cap. 2, p.15-41.

WERNER; H.J; KANTE,G.; MERZ, H.D. Residue determination of the active ingredient and endosulfan sulfate in soil, water, urine and plant material as well as of endosulfan diol and endosulfan lactone in soil, water and urine. Frankfurt: HOECHST, 1987. p.1-21. (report AAL 60/86). 